\title{
VEGETATED TREATMENT AREA EFFECTIVENESS AT REDUCING NUTRIENT RUNOFF FROM SMALL SWINE OPERATIONS IN CENTRAL TEXAS
}

\author{
A Thesis \\ by \\ KORI DENISE HIGGS
Submitted to the Office of Graduate and Professional Studies of Texas A\&M University in partial fulfillment of the requirements for the degree of
MASTER OF SCIENCE

\begin{abstract}
Chair of Committee, Patricia K. Smith
Committee Members, $\quad$ R. Daren Harmel

Kevin Wagner

Head of Department, $\quad$ Stephen Searcy
\end{abstract}

May 2015

Major Subject: Biological and Agricultural Engineering

Copyright 2015 Kori Denise Higgs 


\begin{abstract}
There have been numerous studies, both modeling and field, related to the design and evaluation of vegetative treatment systems used to treat animal feeding operation runoff; however, none of these have studies evaluated the effectiveness of vegetative treatment areas (VTAs) receiving direct runoff from small swine operations $(<100$ animals) during natural rainfall events. Is it possible that a sufficiently sized VTA alone, with no solids pretreatment, can effectively treat direct runoff from small swine operations? This research aims to answer that question and evaluate the effectiveness of VTAs as a practical and cost-effective alternative wastewater management option to protect surface water quality on small swine facilities. Three locations in central Texas were established in 2012, and sampling sites were installed to monitor runoff water quantity and quality at the inlet and outlet of the VTA and a nearby control area not receiving swine effluent. Data show that the VTAs provided substantial treatment of the swine facility runoff in terms of reduced $\mathrm{NO}_{3}-\mathrm{N}, \mathrm{NH}_{4}-\mathrm{N}, \mathrm{PO}_{4}-\mathrm{P}, \mathrm{TN}$, and $\mathrm{TP}$ mean concentrations $(24 \%$ - 91\%) and total loads (50\%-96\%), but VTA runoff was still higher in nutrients than the control site. Further research of design elements and site management impacts on VTA performance is needed to develop guidelines for VTAs as a waste management option at small swine facilities.
\end{abstract}




\section{TABLE OF CONTENTS}

Page

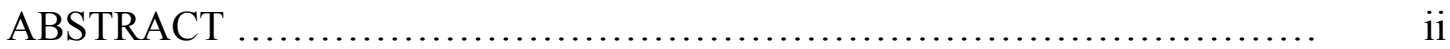

TABLE OF CONTENTS ............................................

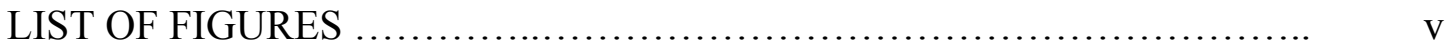

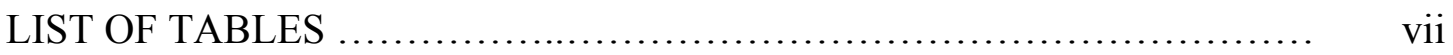

1. INTRODUCTION AND LITERATURE REVIEW ...................... 1

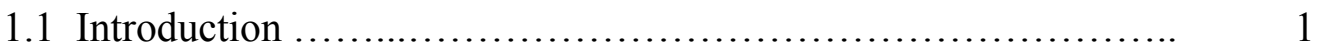

1.2 Literature Review......................................... 3

1.2.1 Impact of Swine Manure on Water Quality.............. 3

1.2.2 Waste Management Options........................... 6

1.3 Research Question, Objectives, and Hypothesis................. 11

2. MATERIALS AND METHODS.................................... 13

2.1 Site Description.............................................. 13

2.2 VTA Design and Setup..................................... 18

2.3 Water Quality Data Collection and Analysis...................... 20

2.3.1 Automated Sampling............................... 20

2.3.2 VTA Management................................. 22

2.3.3 Sample Collection.................................. 23

2.3.4 Sample Analysis..................................... 24

2.4 Soil Quality Data Collection and Analysis ..................... 26

2.5 Statistical Analysis ........................................ 28

3. RESULTS AND DISCUSSION.................................... 31

3.1 Water Quality Analysis................................... 31

3.1 .1 Results......................................... 31

3.1.2 Discussion......................................... 40

3.2 Soil Quality Analysis......................................... 47

3.2 .1 Results............................................. 47

3.2.2 Discussion...................................... 60

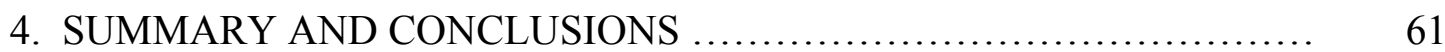




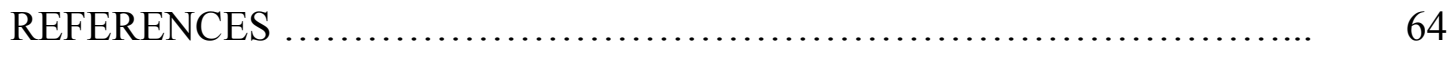

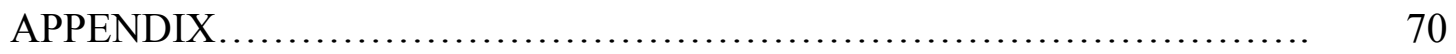




\section{LIST OF FIGURES}

FIGURE Page

$1 \quad$ Map of VTA study locations ............................... 13

2 Bell County site (a) above flume at "VTA In," (b) "VTA In" and runoff distribution system, (c) "Control" site, and (d) view of flume at "VTA Out" with "Control" site in background.........

3 Brazos County site (a) view of pens above flume at "VTA In," (b) culvert through which "Control" site drains, and (c) entire VTA with runoff distribution system.

4 Robertson County site (a) view of "VTA Out" and "Control" sites from "VTA In," (b) barn drainage trench to "VTA In" and runoff distribution system, and (c) view of barn at "VTA In" from "VTA Out.".

$5 \quad$ General VTA layout with samplers and runoff distribution system

6 Boxplots of Bell County concentration data.

7 Boxplots of Bell County event load data.

8 Boxplots of Brazos County concentration data.

9 Boxplots of Brazos County event load data

10 Boxplots of Robertson County concentration data............... 38

11 Boxplots of Robertson County event load data................. 39

12 Relationship between VTA Area/Source Area ratio and percent reduction of the sum of TN and TP based on the average concentrations and total loads for all locations.... 
13 Relationship between VTA Area/\# animals ratio and percent reduction of the sum of TN and TP based on the average concentrations and total loads for all locations.

14 Relationship between VTA slope and percent reduction of the sum of TN and TP based on the average concentrations and total loads for all locations.

15 Inorganic $\mathrm{N}$ in Bell County soil samples (a) $0-15.24 \mathrm{~cm}$ depth, and (b) $15.24-30.48 \mathrm{~cm}$ depth........................... 54

16 Inorganic $\mathrm{P}$ in Bell County soil samples (a) $0-15.24 \mathrm{~cm}$ depth, and (b) $15.24-30.48 \mathrm{~cm}$ depth............................ 55

17 Inorganic $\mathrm{N}$ in Brazos County soil samples (a) $0-15.24 \mathrm{~cm}$ depth, and (b) $15.24-30.48 \mathrm{~cm}$ depth........................... 56

18 Inorganic P in Brazos County soil samples (a) $0-15.24 \mathrm{~cm}$ depth, and (b) $15.24-30.48 \mathrm{~cm}$ depth.......................... 57

19 Inorganic $\mathrm{N}$ in Robertson County soil samples (a) $0-15.24 \mathrm{~cm}$ depth, and (b) $15.24-30.48 \mathrm{~cm}$ depth......................... 58

20 Inorganic P in Robertson County soil samples (a) $0-15.24 \mathrm{~cm}$

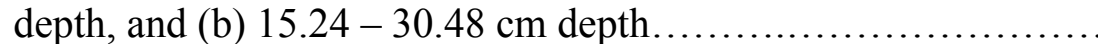




\section{LIST OF TABLES}

TABLE Page

$1 \quad$ General location characteristics .......................... 14

2 Peak discharges and flume sizes........................ 19

3 Summary of Bell County water quality data ................. 34

$4 \quad$ Summary of Brazos County water quality data .............. 37

5 Summary of Robertson County water quality data ............. 40

$6 \quad$ Bell County soil data................................... 48

$7 \quad$ Brazos County soil data................................ 50

$8 \quad$ Robertson County soil data................................ 52

9 Overall summary of water quality results................... 61 


\section{INTRODUCTION AND LITERATURE REVIEW}

\subsection{Introduction}

Agriculture is listed as a major source of excess nutrients in surface water according to the United States Environmental Protection Agency (USEPA) and Texas Commission on Environmental Quality (TCEQ) (USEPA, 2002; TCEQ, 2012). Over application of commercial fertilizer is the primary contributor of agricultural nutrients as farmers are often unsure of optimal crop needs due to uncertainties about weather and soil nutrient availability. Another significant agricultural source of pollutants is animal manure. Since the 1950 's, the number of animals produced has greatly increased, but the number of production facilities has steadily declined. The heightened concentration in animal production has led to manure production in excess of what can be assimilated on site (USEPA, 2003).

In the 2003 ruling regulating concentrated animal feeding operations (CAFOs), the USEPA encouraged all animal feeding operations (AFOs) to manage their waste in a manner protective of water quality, regardless of whether they were classified as CAFOs or not, by adopting nutrient management plans (USEPA, 2003). Hassinger et al. (2000) found in Pennsylvania that larger facilities tended to be more aware of their nutrient management practices and had more safeguards in place to prevent nutrient discharge than smaller operations. This is in part because CAFOs pose a much larger potential environmental risk if poorly managed and, unlike smaller facilities, are legally 
considered point sources and required to obtain a National Pollutant Discharge Elimination System (NPDES) permit (USEPA, 2003).

As a nonpoint source, AFOs are not regulated and their nutrients are typically managed through voluntary efforts (Centner et al., 2008; USDA and USEPA, 1999). In Texas, the Texas State Soil and Water Conservation Board (TSSWCB) is the agency responsible for the abatement and management of agriculturally based nonpoint source pollution (TCEQ, 2012). Their Water Quality Management Plan (WQMP) program is a voluntary program that combines land treatment and management practices and technologies designed to prevent or reduce pollution from agricultural land (TSSWCB, 2004). More than $90 \%$ of hog operations in Texas have less than 100 animals (USDANASS, 2014b). Historically, there has been low participation in the WQMP program among these small swine producers due to the logistic and economic barriers of implementing traditional waste management practices on relatively small pieces of land (TSSWCB, 2005). To encourage participation of small pork producers in the WQMP program, more practical and cost-effective waste management techniques are necessary. A vegetative treatment area (VTA), as defined by United States Department of Agriculture - Natural Resource Conservation Service (USDA-NRCS), is a "vegetative area composed of perennial grass or forages used for the treatment of runoff from an open lot production system or other process waters" (USDA-NRCS, 2006). They are typically part of a vegetative treatment system (VTS) that includes additional components to remove solids, such as a solids settling basin (SSB) or vegetative infiltration basin (VIB) (USDA-NRCS, 2006). Of the few swine-related VTA studies, 
none looked at VTAs receiving direct runoff from hog feedlots with small livestock populations. This study is a preliminary inquiry into the potential effectiveness of minimally and practically designed VTAs to reduce the impact of small swine operations on water quality.

\subsection{Literature Review}

\subsubsection{Impact of Swine Manure on Water Quality}

In an attempt to meet the rising demand for food in the United States and across the globe, modern agricultural practices have focused on attaining higher yields from the same amount of land (Hooda et al., 2000). With the increased number of animals per unit area, the load of contaminants shed by AFOs is often more than the land can assimilate and can serve as a source of pollution for the receiving watershed if improperly managed (Burkholder et al., 2007). The development and implementation of practices to improve the water quality of AFO runoff should begin with an understanding of these pollutants and their environmental impacts.

\subsubsection{Nutrients}

The high nutrient content of animal manure makes it a valuable product, but excess nutrients can be transported via runoff into surface water or accumulate in the soil and leach into the groundwater or be lost through erosion (Khaleel et al., 1980).

Nitrogen $(\mathrm{N})$ and phosphorus $(\mathrm{P})$ are the nutrients of most concern in manure because, in excess, they can accelerate the eutrophication of water bodies which has adverse effects on the aquatic ecosystem (Carpenter et al., 1998). Phosphorus tends to be bound to the soil and is readily available for mineralization to the inorganic form to be taken up by 
plants but $\mathrm{N}$ is more soluble and mobile and tends to be lost in water exiting the system (Heathwaite et al., 1996; Espinoza et al., 2005). Several studies have shown that water bodies close to AFOs are likely to have heightened concentrations of multiple forms of $\mathrm{N}$ and P. Westerman et al. (1995) and Evans et al. (1984) reported nitrate-nitrogen $\left(\mathrm{NO}_{3}-\mathrm{N}\right)$ concentrations of 3-6 mg/L in surface runoff and 7-30 mg/L in subsurface drainage from swine manure spray fields. This is well above the $0.1-0.2 \mathrm{mg} / \mathrm{L}$ that Mallin (2000) described as supportive of algal blooms that can emit harmful toxins as they reproduce or deplete the dissolved oxygen as they consume all the nutrients and start to die off. Either scenario can disrupt the ecosystem and potentially lead to extensive fish kills and the loss of habitat and biodiversity (Carpenter et al., 1998). While both $\mathrm{N}$ and $\mathrm{P}$ contribute to algae growth, $\mathrm{P}$ tends to be the limiting factor for inland waters and $\mathrm{N}$ for estuaries (Sharpley and Withers, 1994).

Besides the environmental impacts of excess nutrients, there are also known links to human health issues. The USEPA standard for drinking water is $10 \mathrm{mg} \mathrm{NO}{ }_{3}-\mathrm{N} / \mathrm{L}$ due to concerns about its links to a raised risk of methemoglobinemia, or blue baby syndrome, in children under six months old (Ward et al., 2005). At even higher concentrations (11-61 mg/L) for prolonged periods of times, nitrate consumption is thought to increase the risk of hyperthyroidism (Burkholder et al., 2007). Other reports have associated varying levels of nitrate exposure (10-25 mg/L) to insulin-dependent diabetes and increased risk for birth defects (Kostraba et al., 1992). 


\subsubsection{Pathogens}

Untreated manure contains a high a load of microorganisms, some of which are known human pathogens. Even waste that is treated in a lagoon, anaerobic digester, or an aerobic process prior to land application can release harmful bacteria, protozoa, and viruses into the environment (Burkholder et al., 2007). One significant pathway of pollution is the conveyance of pathogens to surface and ground water via runoff and leachate, but there are several other potential pathways of microbial transmission including small mammals and birds as vectors or reservoirs, or from the direct contact of grazing animals with water sources (Hooda et al., 2000). Livestock and humans are subject to adverse health effects from coming in direct contact with infected manure, soil, or water, or from consuming tainted produce or meat.

Escherichia coli (E. coli), fecal coliforms (FC), and total coliforms (TC), have traditionally been used to assess bacterial contamination levels, but Campylobacter, Salmonella, and Yersinia bacterium are also associated with swine waste and known to cause illness in humans (USEPA, 2013; Hooda et al., 2000). Cryptosporidium and Giardia are two protozoan parasites known to cause gastroenteritis and other gastrointestinal issues that are commonly found in surface waters receiving feedlot runoff(USEPA, 2013). Depending on factors such as $\mathrm{pH}$, temperature, solar radiation, and the presence of nutrients, these microbes can survive for up to 36 months in feces, 31 months in soil, and 47 days in water, making the onsite retention of AFO waste and water an important focus for bacterial mitigation (Sherer et al., 1992). Also of importance is the consideration of how bacteria from animals who receive low doses of 
anti-microbial medicine, which can encourage the selection of drug resistant genes in bacterial populations, can impact public and environmental health (Burkholder et al., 2007).

\subsubsection{Pharmaceuticals}

Millions of kilograms of anti-microbials are used annually in animal production systems. They are used both therapeutically to treat infections and sub-therapeutically to increase growth rates among swine, cattle, and poultry (Lee et al., 2007). Because they are not well absorbed in the intestinal tract, up to $90 \%$ of the drugs administered can be excreted in the urine and manure, depending on the particular compound in question (Lee et al., 2007). For facilities with large animal populations, this can translate to a waste stream with a high occurrence of these medications which, in turn, end up in the water and soil on and around the site. For example, one study reported that antimicrobials were found in $31 \%$ and $67 \%$ of surface and ground water samples of swine and poultry farms, respectively, although the concentrations were typically low (Campagnolo et al., 2002). Hormones can have potentially harmful impacts on wildlife as an endocrine disrupting compound (EDC), but hormones specifically linked to AFO waste streams have not yet been directly linked to illnesses in humans (Lee et al., 2007).

\subsubsection{Waste Management Options}

An important aspect of decreasing the input of harmful contaminants into the environment from AFOs is responsible management of waste so that water, soil, and manure stay on site for as long as possible to allow the progression of natural cycles that can help reduce their concentrations (Khaleel et al., 1980). Limiting the amount of 
erosion, runoff, and leaching of pollutants are key strategies in attaining that goal (USEPA, 2013). Typical waste management practices, like lagoons and land application, can discharge excessive nutrients and pathogens into the environment when not utilized properly (Mallin, 2000). However, if time and effort are invested in planning appropriate procedures for handling the manure, the potential of spreading contamination can be minimized. Studies of the impact of AFOs and CAFOs on water quality have yielded useful recommendations on how to best manage waste streams and the physical site to mitigate associated risks. The following is a review of some of those options.

\subsubsection{Land Application}

Because animal waste is rich in nutrients, many operators choose to use it as fertilizer for their crop and pasture lands. However, the actual nutrient content of the feces varies greatly depending on the animal, feeding regimen, how long the waste has accumulated, the moisture content, and how much bedding material is included (Sharpley and Withers, 1994). Managing the rate, timing, and method of land application can greatly reduce the release of manure-based pollutants into the environment. Ideally, the $\mathrm{N}$ and $\mathrm{P}$ content of the manure and soil should be determined and used to establish an appropriate application rate to provide nutrients without over loading the land beyond its capacity. Greater loss of nutrients and other contaminants can occur if the ground is water-logged, frozen, or covered in snow, or if precipitation events are in the forecast at the time of manure spreading, so it is best to reschedule in these instances (Sharpley et al., 2004). It has also been shown that incorporating the 
waste into the soil by tilling it in or direct injection helps to lower losses from the manure (Mueller et al., 1984). If tilling will be done, employing soil conservation practices, such as contouring and conservation tillage, to prevent loss of soil-bound contaminants is highly recommended (Khaleel et al., 1988).

\subsubsection{Waste Lagoons}

Many sites also store waste or make use of physical, biological, and chemical processes to preemptively reduce the input of contaminants. The anaerobic conditions created in well-constructed and maintained storage lagoons have been shown to lower concentrations of nutrients and microbial pathogens (Bicudo and Goyal, 2003).

However, leaks and ruptures are common for poorly designed, constructed or managed facilities, and they can also overflow during intense precipitation, which can have a substantial negative environmental impact (Mallin, 2000). Anaerobic digesters have been used to stabilize and reduce odor from swine manure in addition to lagoon storage, and if designed to include a thermophilic anaerobic regime, they can provide significant levels of bacterial disinfection (Bicudo and Goyal, 2003).

\subsubsection{Constructed Wetlands}

Constructed wetlands have been studied as a potential treatment option to work in conjunction with other waste management practices such as storage lagoons, solids settling, and land application (Gersberg et al., 1989; Cronk, 1996). The prolonged interaction of the water with the soil and plants within the wetland provides several mechanisms by which nutrients, pathogens, and other contaminants can be removed (Knight et al., 2000). High $\mathrm{N}$ reduction rates have been reported, due in large part to the 
microbial-driven process of denitrification, which has been reported as the most important means of $\mathrm{N}$ removal in wetlands, and plant uptake (Cronk, 1996). Shallow, slow-moving water through the system is another key component in treating animal waste because it allows for the settling of solids and sediments (Richardson, 1985). This is helpful in the removal of $\mathrm{P}$ because it tends to be adsorbed to soil particles, although $\mathrm{P}$ reduction may be less in wetlands than on dry soil because the adsorption process is inhibited by the anaerobic conditions (Richardson, 1985). In studies of domestic wastewater, indicator bacteria and virus concentrations shrank by $90-99 \%$ due to sun exposure, predation and competition with other microbes, and toxins, and imply high potential in abating pathogens from animal waste (Gersberg et al., 1989).

\subsubsection{Vegetative Treatment Options}

A VTA, also called a vegetative filter strip (VFS) or buffer strip, is a tract of land that uses the biological and physical processes at the interface of soil, water and vegetation to remove pollutants in runoff from upland contamination sources (Koelsch et al., 2006). When used for AFO waste management, they are typically part of a VTS which includes a SSB or VIB to remove solids from the waste stream before it enters the VTA (Koelsch et al., 2006). Contaminants leaving open feedlots and waste application fields with runoff, either in solution or bound to eroded soil particles, are removed as the overland velocities are reduced, allowing the processes of settling, filtration, adsorption, and infiltration to occur (Dickey and Vanderholm, 1981). Plant uptake and microbial activity are also important to VTA function (Woodbury et al., 2006). They may be entirely planted with one species of grass or contain a variety of pasture or prairie 
vegetation (Koelsch et al., 2006). Because infiltration plays such an important role in its function, VTAs with soils that are well drained tend to exhibit better performance (Sharpley et al., 2004). The mechanisms of pollutant removal are more successful at removing suspended elements than dissolved ones so it is particularly effective in retaining particulate $\mathrm{N}$ and $\mathrm{P}$, sediment, and microbes (Koelsch et al., 2006). However, efficiency suffers when the filter strip is on steep slopes ( $>4 \%)$, receives channelized flows, or when dried solids accumulate in the field to form a barrier between the runoff, soil, and vegetation (Komor and Hansen, 2003; Dickey and Vanderholm, 1981; Koelsch et al., 2006).

There have been numerous studies, both modeling and field, related to the design and evaluation of VTSs used to treat AFO runoff (Koelsch et al., 2006). A majority of these studies assessed the effectiveness of VTSs on cattle AFOs (e.g., Edwards et al.; 1983; Komor and Hansen, 2003; Woodbury et al., 2005). However, there are a limited number of similar swine-related studies. Chaubey et al. (1994) examined rainfall simulator-induced runoff at different downslope distances on a VFS treated with swine manure from a waste pit. They found that the VFS substantially reduced (65-99\%) the loads of ammonium nitrogen $\left(\mathrm{NH}_{4}-\mathrm{N}\right)$, total Kjeldahl $\mathrm{N}(\mathrm{TKN})$, orthophosphate $\left(\mathrm{PO}_{4}-\mathrm{P}\right)$, and total P (TP) but had no meaningful effect on $\mathrm{NO}_{3}-\mathrm{N}$ load. No substantial increase in nutrient removal occurred beyond a treatment length of 9 m. Hawkins et al. (1998) studied runoff of swine lagoon effluent applied to a VFS and found that outflow from the VFS showed a $60-93 \%$ mass reduction in $\mathrm{N}$ and $\mathrm{P}$ relative to inflow, mostly due to the retention of $85-100 \%$ of the runoff. Dickey and Vanderholm (1981) studied the 
effectiveness of a vegetated terrace channel and grassed waterway designed to treat runoff from swine and cattle AFOs. They found nutrient reductions of $80 \%$ and $90 \%$ in concentrations and loads, respectively, and that overland flow was more effective than channelized flow at treating the effluent.

\subsection{Research Question, Objectives, and Hypothesis}

None of these previously mentioned studies evaluated the effectiveness of VTAs receiving direct runoff from small swine operations during natural rainfall events. Most of the studies were of VTSs which involved pretreatment of the solids prior to the VTA that can take up valuable space and may require more of a financial commitment from the operator. This research sought to determine if a sufficiently sized VTA alone can effectively treat direct runoff from small swine AFOs during daily operation and natural rainfall events. It would provide a preliminary evaluation of the potential effectiveness of VTAs as a practical and cost-effective alternative wastewater management option for small swine facilities to protect surface water quality. The objectives of this study were to: 1) evaluate the effectiveness of a stand-alone VTA at removing N and P from swine facility runoff, and 2) compare the VTA effluent to local ambient water quality to evaluate VTA effectiveness.

Based on previous research, it is anticipated that there will be a considerable reduction in nutrient concentrations and loads between the VTA inlet and outlet, indicating that a solitary VTA can improve runoff water quality from small hog AFOs. How results may have been impacted by different elements of the project and options for altering VTA management and design to improve its performance will be discussed, as 
well as future research needed to fully evaluate the use of VTAs for small swine operations. 


\section{MATERIALS AND METHODS}

\subsection{Site Description}

Three research locations were established in September through December 2012 at small swine AFOs in Bell, Brazos, and Robertson counties in central Texas (Figure 1). In each county, three sampling sites were installed to monitor runoff water quantity and quality at the inlet and outlet of the VTA, and exiting a nearby control area. Locations were chosen based on size of operation, availability of appropriate land for VTA establishment, and relative distance to laboratory facilities. General characteristics for each location are listed in Table 1 and described in detail below.

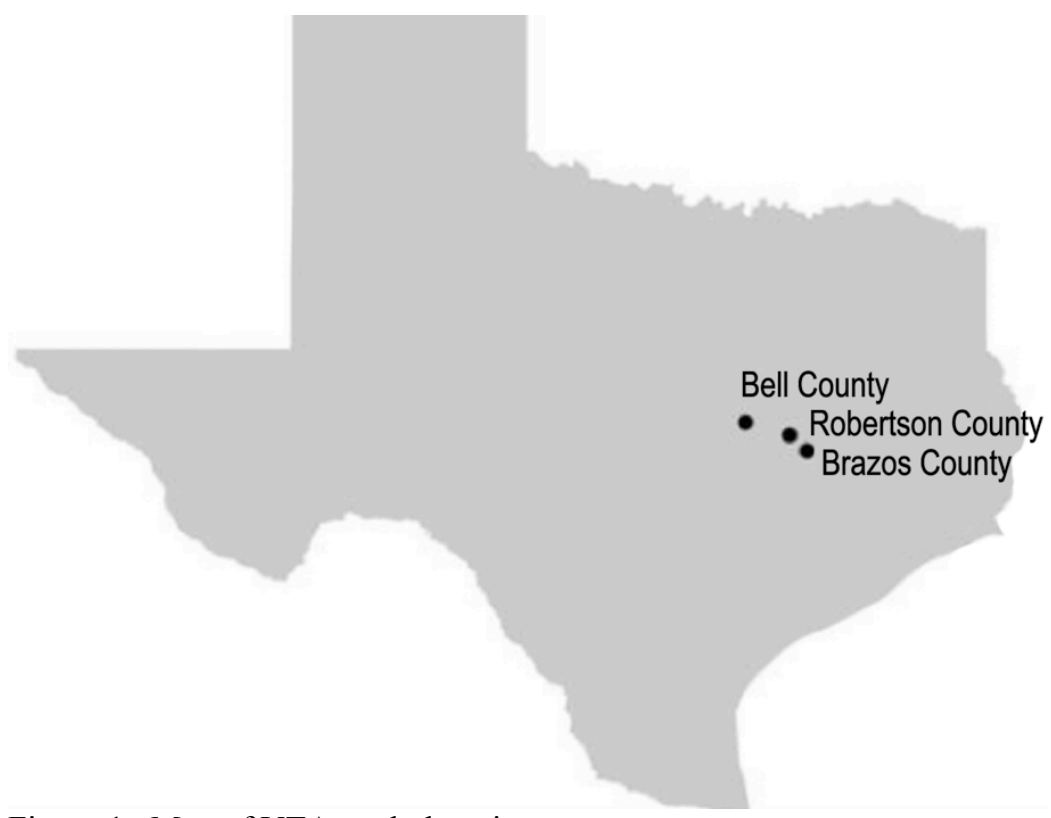

Figure 1. Map of VTA study locations 
Table 1. General location characteristics

\begin{tabular}{|c|c|c|c|c|c|c|c|c|}
\hline $\begin{array}{l}\text { Location } \\
\text { (County) }\end{array}$ & $\begin{array}{c}\text { Source } \\
\text { area } \\
\text { (ha) }\end{array}$ & $\begin{array}{l}\text { VTA } \\
\text { area } \\
(\text { ha })^{[\mathbf{a}]}\end{array}$ & $\begin{array}{c}\text { Control } \\
\text { area } \\
\text { (ha) }\end{array}$ & $\begin{array}{c}\text { VTA } \\
\text { area/ } \\
\text { Source } \\
\text { area ratio } \\
\end{array}$ & $\underset{(\#)^{[b]}}{\operatorname{Animals}}$ & $\begin{array}{c}\text { VTA area/ } \\
\text { Animal } \\
\text { ratio } \\
\left(\mathbf{m}^{2} / \mathbf{p i g}\right) \\
\end{array}$ & $\begin{array}{c}\text { VTA } \\
\text { Vegetation[c] }\end{array}$ & $\begin{array}{c}\text { VTA } \\
\text { Slope } \\
(\%)\end{array}$ \\
\hline Bell & 0.15 & 0.34 & 0.48 & 2.3 & 50 & 70 & $\begin{array}{c}\text { Coastal } \\
\text { Bermuda/oats }\end{array}$ & 2.0 \\
\hline Brazos & 0.10 & 0.40 & 1.2 & 4.0 & 20 & 160 & $\begin{array}{c}\text { Native } \\
\text { Pasture/oats }\end{array}$ & 2.5 \\
\hline Robertson & 0.03 & 0.11 & 0.16 & 3.7 & 8 & 140 & $\begin{array}{c}\text { Native } \\
\text { Pasture/oats }\end{array}$ & 1.6 \\
\hline
\end{tabular}

The Bell County location (Figure 2) consisted of 0.15 ha of barn and outdoor pen areas that contain approximately 30-100 animals. The soil was Houston Black clay which is a moderately well drained, highly expansive clay that is very slowly permeable when wet (USDA-NRCS, 1997a). Waste from the enclosed pens on the north side of the site drained via pipe directly to the inlet of the VTA. Runoff from the unsheltered pens drained to the east and was redirected to the VTA inlet with berms. The VTA itself was 0.34 ha of coastal Bermuda grass on a $2 \%$ slope, over-seeded with oats in the winter, isolated from surrounding fields with earthen berms. The control site is 0.48 ha of rural land above the pens that drained through a grassed waterway to the south of the fields that emptied into a small farm pond. Runoff into the inlet of the VTA was routed to a $0.46 \mathrm{~m} \mathrm{H}$-flume by berms. For the VTA outlet and the control area, $0.61 \mathrm{~m} \mathrm{H}$-flumes were used in conjunction with berms. 

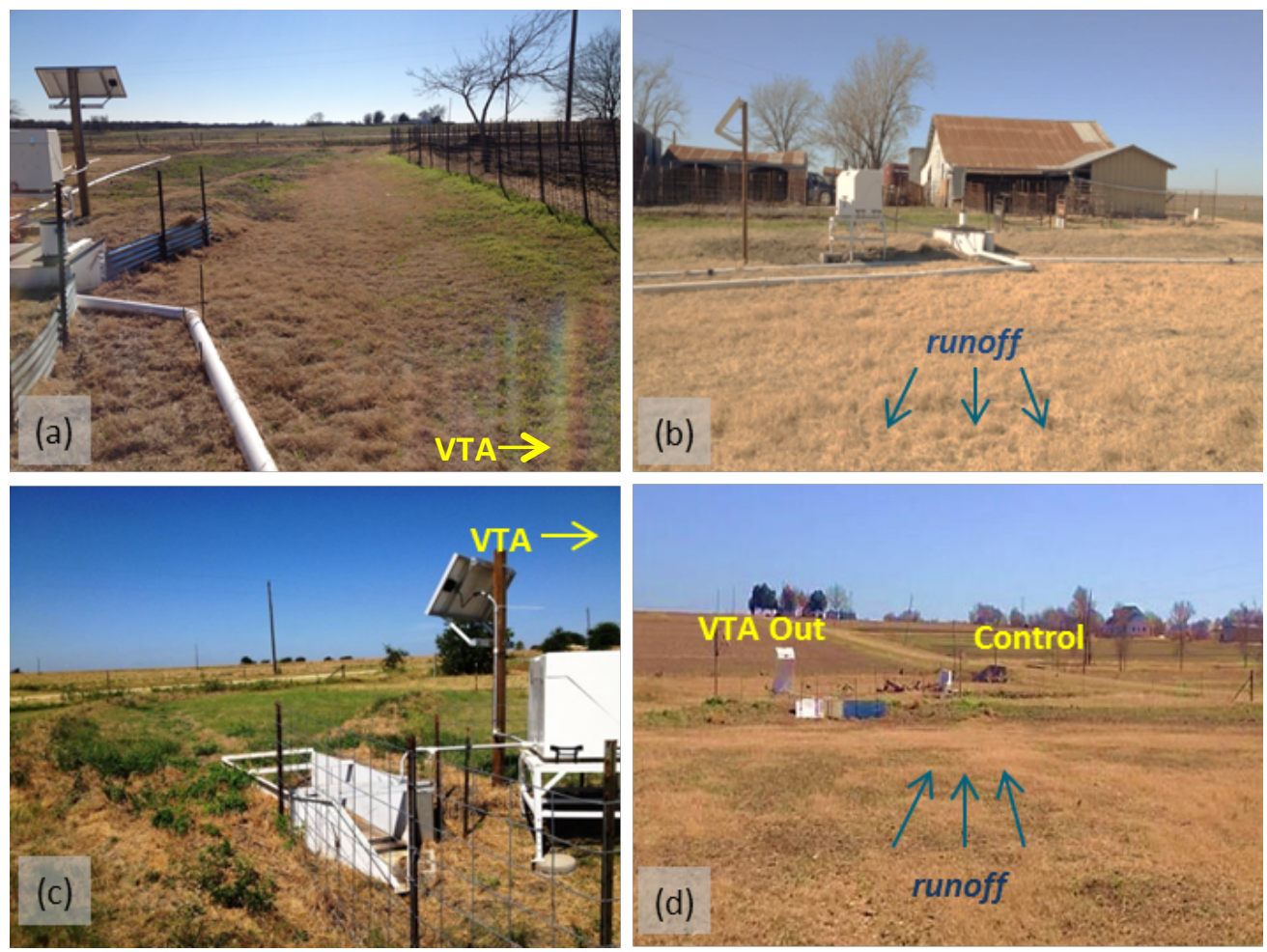

Figure 2. Bell County site (a) above flume at "VTA In," (b) "VTA In" and runoff distribution system, (c) "Control" site, and (d) view of flume at "VTA Out" with "Control" site in background.

In Brazos County (Figure 3), the facility was 0.1 ha of barn and outdoor pens that holds approximately 10-30 animals. This soil was a mix of Boonville fine sandy loam and Zack fine sandy loam which are poorly to moderately well-drained and very slowly permeable soils (USDA-NRCS, 2002a and 1997b). Waste from the pens drained from the south side onto a 0.4 ha treatment area that was a native prairie on a $2.5 \%$ slope overseeded with oats in the winter. A 1.2 ha rural residential area northwest of the barns was monitored as the control area. A $0.46 \mathrm{~m}$ and $0.30 \mathrm{~m} \mathrm{H}$-flume were used for the VTA outlet and inlet, respectively. The control area drained through a culvert in which an area-velocity meter is installed to monitor flow. 

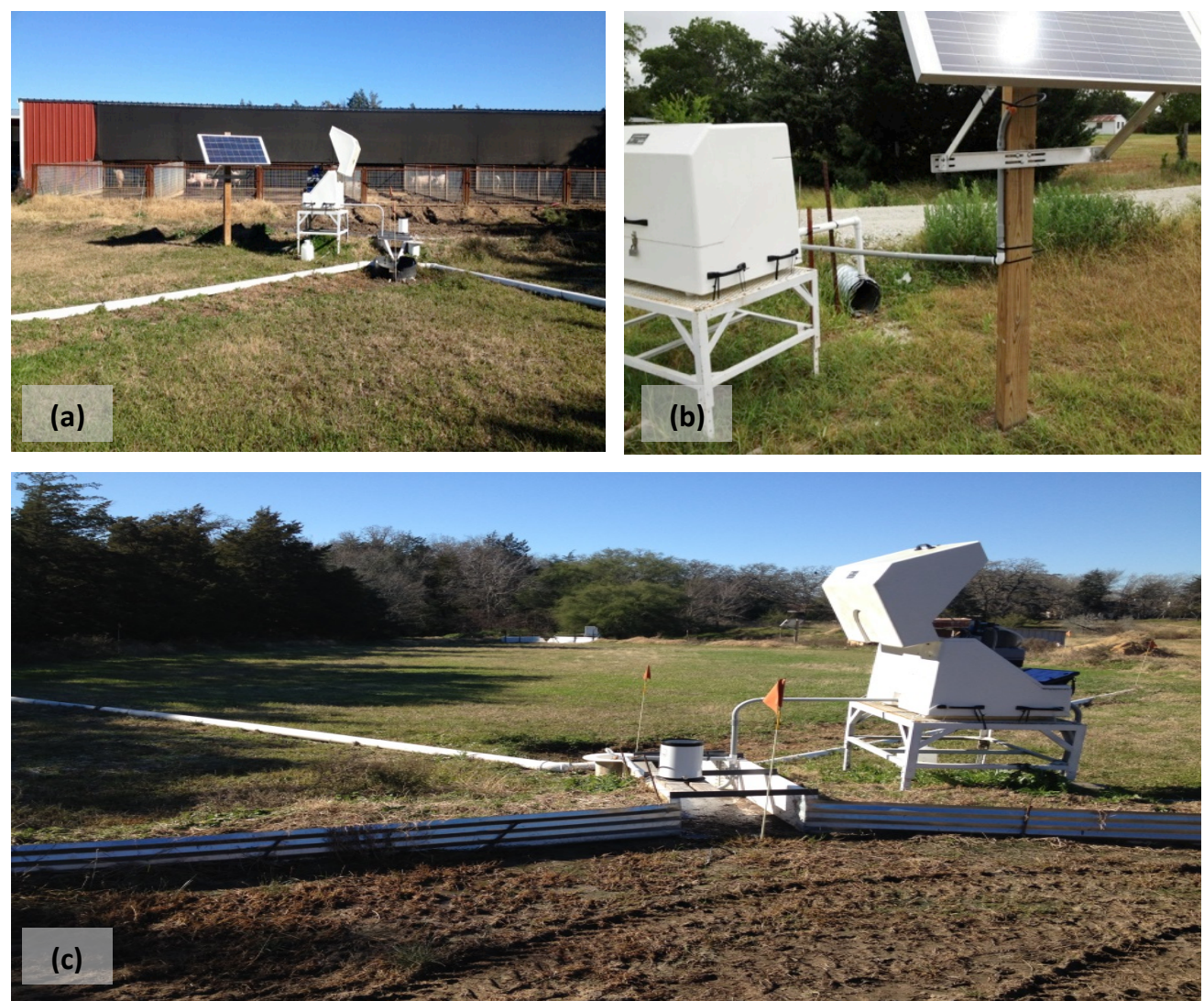

Figure 3. Brazos County site (a) view of pens above flume at "VTA In," (b) culvert through which "Control" site drains, and (c) entire VTA with runoff distribution system.

The Robertson County operation (Figure 4) consisted of a 0.03 ha area with an outdoor walking pen and barn that housed an average of 5-20 animals. The soils in this area were dominated by Tabor fine sandy loam, a moderately well-drained soil that is very slowly permeable when wet (USDA-NRCS, 2002b). Waste was washed out the southwest corner and south wall of the barn on a weekly basis and used bedding was periodically applied to the walking pen on the west side of the barn. All wash water and runoff was directed to the inlet of the VTA via a system of drainage trenches and berms. 
On the south side of the barn was a native prairie field on $1.6 \%$ slope, over-seeded with oats in the winter, from which a 0.11 ha VTA and adjacent 0.16 ha control site were sectioned off using berms. At the inlet and outlet of the VTA, $0.30 \mathrm{~m}$ and $0.46 \mathrm{~m} \mathrm{H}$ flumes, respectively, were installed to monitor flow. A $0.46 \mathrm{~m} \mathrm{H}$-flume was also installed at the outlet of the control site to monitor runoff.
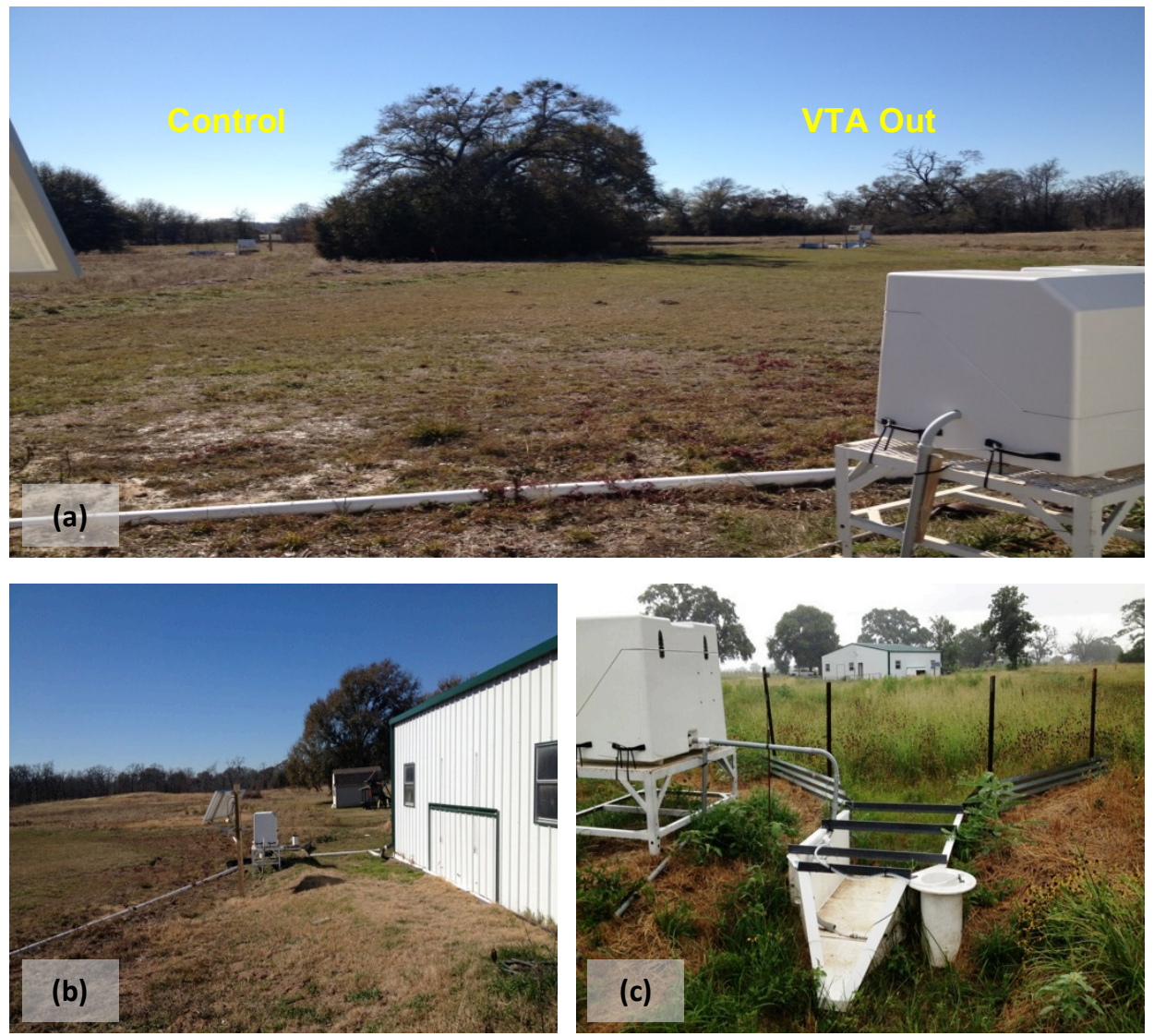

Figure 4. Robertson County site (a) view of "VTA Out" and "Control" sites from "VTA In," (b) barn drainage trench to "VTA In" and runoff distribution system, and (c) view of barn at "VTA In" from "VTA Out." 


\subsection{VTA Design and Setup}

In an extensive review of VTA studies spanning nearly 40 years of research Koelsch et al. (2006) found that pre-treatment, sheet flow, discharge control, siting, and sizing are the main design factors that need to be considered to create a highly functioning VTA. The Koelsch et al. (2006) study reviewed VTAs for facilities with 420 times more animal units than the operations used in this project. Though these recommendations were factored into the overall design, some elements were altered to ensure practicality and economic feasibility for small facilities. The major departure from the design suggestions was the lack of solids pretreatment because the main question of this study was whether a stand-alone VTA is sufficient for small operations. Discharge control, VTA siting, and VTA sizing are all closely related in that if the VTA is not properly sized or sited, discharge of runoff could be too much or too fast and reduce treatment efficiency (Sharpley et al., 2004; Dickey and Vanderholm, 1981). The most important element for consideration in the design was the ratio of the VTA area relative to the contributing area, which is one of the sizing approaches Koelsch et al. (2006) deemed most suitable for smaller AFOs.

Flume sizes were chosen based on peak discharge as calculated using Worksheet 2 from Chapter 2 of the USDA-Soil Conservation Service Engineering Field Handbook (USDA-SCS, 1984). It used equations and nomographs relating drainage area, soil type, land cover, flow length and slope, and rainfall distribution patterns to determine time of concentration and initial abstraction. The peak discharges were then determined for a 25-year, 24-hour event and used to choose an appropriately sized flume (Teledyne Isco, 
2011). Worksheets and data used for the calculations are listed in the appendix and calculated discharges with corresponding flume sizes are listed in Table 2. Peak flow through the culvert at the Brazos County control site was calculated by the Brazos County USDA-NRCS office, who also conducted the site survey, utilizing their own hydrology worksheet. The data from those calculations are also listed in the appendix.

Table 2. Peak discharges and flume sizes

\begin{tabular}{cccccccccc}
\hline & \multicolumn{3}{c}{ Bell County } & \multicolumn{3}{c}{ Brazos County } & \multicolumn{3}{c}{ Robertson County } \\
& $\begin{array}{c}\text { VTA } \\
\text { In }\end{array}$ & $\begin{array}{c}\text { VTA } \\
\text { Out }\end{array}$ & Control & $\begin{array}{c}\text { VTA } \\
\text { In }\end{array}$ & $\begin{array}{c}\text { VTA } \\
\text { Out }\end{array}$ & Control ${ }^{[\mathrm{a}]}$ & $\begin{array}{c}\text { VTA } \\
\text { In }\end{array}$ & $\begin{array}{c}\text { VTA } \\
\text { Out }\end{array}$ & Control \\
\hline Peak discharge (cfs) & 2.9 & 8.8 & 3.0 & 1.1 & 3.9 & 6.0 & 1.9 & 2.4 & 2.3 \\
& 1.5 & 2.0 & 2.0 & 1.0 & 1.5 & 1.0 & 1.0 & 1.5 & 1.5 \\
Flume size (ft) & 1.5 & &
\end{tabular}

Since sheet flow was recommended for maximum treatment efficiency, the wastewater and runoff that was concentrated at the VTA inlet for measurement purposes must be spread out across the width of the treatment area after flowing through the flume (Figure 5) (Dillaha et al., 1988; Dickey and Vanderholm, 1981). Thus, a runoff distribution system was constructed of a $15.24 \mathrm{~cm}$ deep tank, which received outflow from the flume, and $10.16 \mathrm{~cm}$ PVC pipes installed laterally approximately $2.54 \mathrm{~cm}$ from the top of the tank. In these pipes, $2 \mathrm{~cm}$ holes were drilled starting $3 \mathrm{~m}$ from the tank and every $1.5 \mathrm{~m}$ thereafter, essentially creating a gated pipe. For non-research 
applications, this distribution system would be unnecessary because there would be no need to concentrate flow through a single point to measure or test the water.

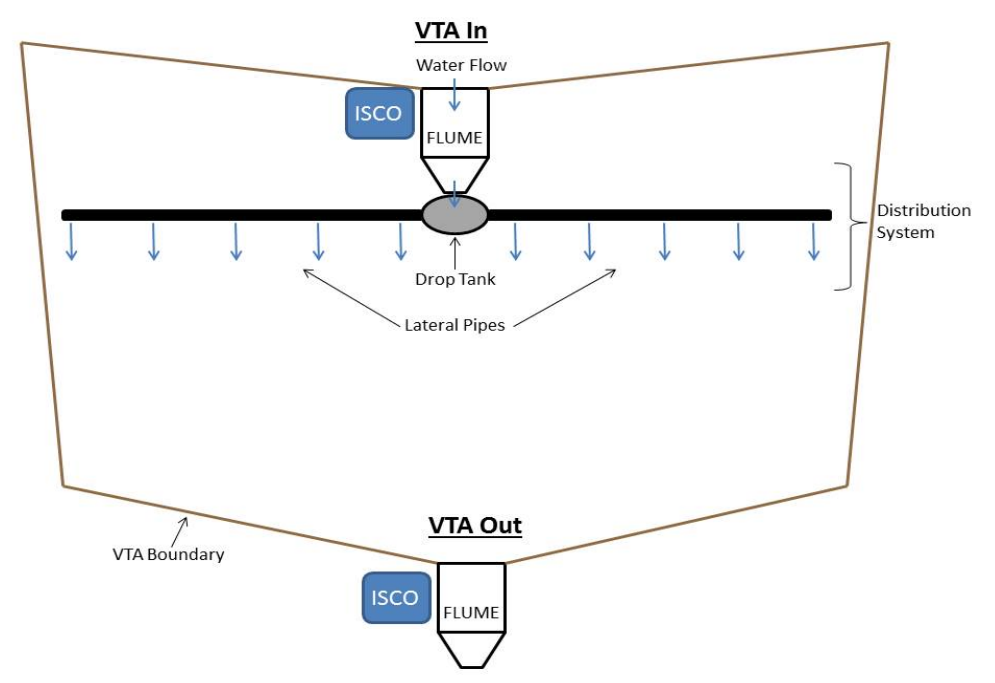

Figure 5. General VTA layout with samplers and runoff distribution system

\subsection{Water Quality Data Collection and Analysis}

\subsubsection{Automated Sampling}

Each sampling station was equipped with a Teledyne ISCO Avalanche Portable Refrigerated Sampler with site specific programming to collect a $200 \mathrm{~mL}$ sample at 0.5 $1.5 \mathrm{~mm}$ volumetric depth flow intervals. The original intent was to collect a sample every $1.32 \mathrm{~mm}$ of volumetric depth which is within the range that Harmel et al. (2006b) suggest to improve the sample's representation of the storm event and decrease data uncertainty. However, in the second year of the study it was discovered that calculations of the volumetric flow interval were based on the wrong areas so actual volumetric depth 
intervals were incorrect. To maintain a consistent sampling regimen for the duration of the project, and because the intervals were still small enough to collect a representative sample, flow intervals in the program were not changed to reflect the originally intended value.

Collected samples were composited into a single $20 \mathrm{~L}$ bottle instead of several individual bottles to ensure events with a long duration would be accurately characterized, as described by Harmel et al. (2006a, b). The resulting nutrient data represented the event mean concentration (EMC). This flow-weighted sampling protocol and the EMC it produced provided a representative picture of the flux of nutrients from the contributing areas and allows for easy conversion from concentrations to loads. Prior to collection of each subsample, the sampler tubing was rinsed and purged with ambient water to decrease likelihood of sample contamination.

At every station with an H-flume, ISCO 730 Bubbler Flow Modules were used to monitor water level and flow rates. Alternatively, the station with a culvert utilized an ISCO 750 Area Velocity (A-V) Module. The bubbler gauged the amount of pressure needed to force a metered amount of air out of the bubbler tube into the stilling well and used that pressure head to determine the water level (Teledyne Isco, 2013a). The A-V module emitted an ultrasonic signal and determined the fluid velocity by measuring the Doppler shift in the wavelengths as they bounced off suspended particles in the water (Teledyne Isco, 2013b). Similar to the bubbler, the A-V module determined the depth of flow from pressure readings of its internal pressure transducer. The sampler used these 
measurements and the internally stored dimensions of the flumes, or culvert, to calculate flow rates.

\subsubsection{VTA Management}

Weekly site checks were conducted to ensure equipment functioned as intended in storm events. The bubbler was first checked to see if it was sending out a steady bubble every 1-3 seconds to make sure changes in water level would be quickly and correctly assessed (Teledyne Isco, 2013c). Bubblers were also checked for accuracy by filling the stilling well and observing the stage readings as the water receded to the zero level. If the sampler did not respond to the rising water and then even out to zero, the level was manually adjusted to reflect the true water level (Teledyne Isco, 2013c). If the time between bubbles was too high and was not resolved by clearing any blockages in the line, or if stage readings could not be validated and stabilized, bubbler modules were replaced and sent to Teledyne ISCO for maintenance (Teledyne Isco, 2013c). Desiccant tubes, suction hose, and bubbler tubing were also replaced as needed. The solar panel and battery combination was checked to ensure a sufficient power for storm events.

The flume and distribution system were also regularly checked for functionality. For the stage-to-flow relationship of the flume to hold true, it must remain level (Teledyne Isco, 2011). If during the bubbler check, outflow from the stilling well was not obviously evenly distributed, the flume level was checked and adjustments were made as needed. Periodically, the outfall of the flume had to be re-trenched to make sure flow through would be allowed to freefall out of the flume, which is also important for its proper function (Teledyne Isco, 2011). The distribution system was inspected to 
ensure pipes were free of debris, connections between pipe sections were intact, and that flowing water would reach the end of each distribution arm.

Because plant uptake was key to VTA removal of nutrients, the only fertilization the fields received came from the AFO runoff (Dickey and Vanderholm, 1981). From previous studies that showed the reduction of nutrient load by a VTA is due in large part to the reduction in the amount of runoff leaving the field, it can be assumed that much of the nutrients remain within the VTA system until the vegetation is removed (Woodbury et al., 2005; Barker and Young, 1984). Therefore, VTA fields were hayed once or twice during each growing season, as needed, to completely remove the nutrients from the system.

\subsubsection{Sample Collection}

Sites were monitored and data collected from January 2013 through November 2014. Weekly maintenance checks were made to ensure proper working order of all equipment and to make on-site adjustments as needed. At each location, the sampler at the VTA inlet was equipped with a ISCO 674 Tipping Bucket Rain Gauge for site specific precipitation data, and an ISCO $6712 \mathrm{Ci}$ modem to allow remote communication with the sampler unit. During a runoff event, alarms were sent out when the minimum flow threshold was reached and the programs were enabled. Subsequent status updates were then requested wirelessly to determine when the first sample was taken. Within 24 $\mathrm{h}$ of the first sample, each composite sample was thoroughly mixed, poured into three 20 $\mathrm{mL}$ high density polyethylene bottles, and transported on ice to the USDA-ARS Grassland, Soil, and Water Research Laboratory for nutrient analysis. 


\subsubsection{Sample Analysis}

$\mathrm{PO}_{4}-\mathrm{P}, \mathrm{NH}_{3}-\mathrm{N}$, and $\mathrm{NO}_{3}-\mathrm{N}$ concentrations were determined utilizing a SEAL AA3 Segmented Flow Analyzer in which samples were introduced to a continuous flow of chemical reagents that had been divided into segments by air bubbles (SEAL Analytical, 2011). The bubbles created a turbulent flow within each liquid segment that rapidly mixed the two streams, allowing the steady-state of the chemical reaction to be reached quickly (SEAL Analytical, 2011). By passing through a copper-cadmium column, $\mathrm{NO}_{3}-\mathrm{N}$ was reduced to $\mathrm{NO}_{2}-\mathrm{N}$ (nitrite), which first reacted with sulfanilamide and then N1-naphthyethylenediamine dihydrochloride to form an azo dye with a reddishpurple hue (SEAL Analytical, 2010). $\mathrm{NH}_{4}-\mathrm{N}$ was reacted with salicylate and phenate with a nitroprusside catalyst to create a blue compound for analysis (SEAL Analytical, $2012 b$ ). With antimony potassium as the catalyst, $\mathrm{PO}_{4}-\mathrm{P}$ reacted with molybdate and ascorbic acid to also form a blue compound (SEAL Analytical, 2009).

Nutrient concentrations, which were proportional to the intensity of the color compound formed in the reaction, were determined by measuring the amount of light of a specific wavelength absorbed by the mixed sample in this steady state and comparing it to that of standards of known concentrations under identical conditions (SEAL Analytical, 2012a). $\mathrm{NO}_{3}-\mathrm{N}, \mathrm{NH}_{4}-\mathrm{N}$, and $\mathrm{PO}_{4}-\mathrm{P}$ were measured at 520, 660, and $880 \mathrm{~nm}$, respectively (SEAL Analytical 2009, 2010, 2012b). These photometric methods are based on the Lambert-Beer law that states, when all other parameters are held constant, there is a direct linear relationship between the concentration of analyte in a solution and that solution's absorbance (SEAL Analytical, 2011). However, this linear relationship is 
distorted at very high concentrations and samples should be diluted to avoid error (SEAL Analytical, 2012a).

The SEAL AACE software that controlled AA3 operation used the absorbances of the standards to create a calibration curve, with $\mathrm{R}^{2} \geq 0.999$, from which the unknown concentrations of samples could be calculated (SEAL Analytical, 2011). The absorbance of each sample and standard showed up as a peak on a continuous line that can drift over time due to carryover between measurements (SEAL Analytical, 2011). The baseline drift was the difference in the line height while the sample aspirator is in the wash solution and the sensitivity drift was the difference in absorbance peak height for the highest standard, both measured at the beginning and end of the sample run (SEAL Analytical, 2012a). Based on the assumption of drift linearity over time, a different portion of the drifts were applied to each absorbance peak and a final corrected concentration was reported (SEAL Analytical, 2012a).

TN concentrations were determined via a chemiluminescence process using a Teledyne Tekmar Apollo 9000 combustion total organic carbon (TOC) analyzer with a TN module (Teledyne Instruments, 2003). All N in the samples was converted to nitric oxide (NO) via catalytic combustion oxidation (Neumann et al., 2012). The NO was then reacted with ozone $\left(\mathrm{O}_{3}\right)$ to create nitrogen dioxide in an excited state $\left(\mathrm{NO}_{2}{ }^{*}\right)$ (Teledyne Instruments, 2003). Light energy emitted by the $\mathrm{NO}_{2}{ }^{*}$ as it returned to its ground state, which was proportional to the amount of NO present in the sample, was detected by a chemiluminescence photodiode detector and converted to an electrical signal for quantification (Teledyne Instruments, 2003). A blank correction was applied 
to the three measurements for each sample from which the mean was calculated and compared to internal calibration data to determine TN concentration (Teledyne Instruments, 2003).

Inductively coupled plasma-optical emission spectroscopy (ICP-OES) was utilized to determine TP content of the samples with a Varian Vista-MPX CCD Simultaneous ICP-OES (Varian Instruments, 2001). Samples were aerosolized and injected into an axially-viewed radiofrequency-induced argon plasma torch that, at a temperature of $10,000 \mathrm{~K}$, quickly vaporized the sample and released free atoms of the analytes (Hou and Jones, 2000). The plasma further energized the atoms into an excited state causing the emission of photons proportional to the concentration of analyte and with a wavelength characteristic of the atom from which it originated (Hou and Jones, 2000). The arrangement of the 1.1 million pixels (or megapixel, MPX) in the charge coupled device (CCD) detects wavelengths of $96 \%$ of the analytical light spectrum, allowing for simultaneous measurement of several elements (Knowles, 2010). This broad coverage also provided the ICP-Expert software with multiple wavelengths to use with internal and user-provided calibration standards for more accurate concentration determinations to which background corrections were applied (Knowles, 2010).

\subsection{Soil Quality Data Collection and Analysis}

A set of soil samples, with 12 sample points in Bell County and 10 points each in Brazos and Robertson Counties, was collected biannually in April and October from each location. The sampling sites were determined by overlaying an aerial photo of each location with a grid in which each block represented the total VTA area divided by the 
number of samples to be collected. The physical location of each site was marked by screwing two large washers to the top of a wooden stake and driving it beneath the surface of the ground. GPS coordinates were also taken in case the site could not be found by future metal detection and for mapping purposes.

After clearing away surface litter, but leaving any black decomposing matter, a soil sampler probe was used to collect two core samples, one representing the $0-15.24$ $\mathrm{cm}$ layer and another for the 15.24-30.48 cm layer. Soil samples were analyzed for total, inorganic, and organic $\mathrm{N}$ and $\mathrm{P}$ utilizing an enhanced soil test developed by Haney et al. (2006, 2008, 2010). Because these methods focus on plant available portions of the organic and total $\mathrm{N}$ and $\mathrm{P}$ pools, only the inorganic $\mathrm{N}$ and $\mathrm{P}$ data were analyzed for potential spatial and temporal trends within each VTA.

Maps were created in ArcGIS 9.3 by first using the GPS coordinates and soil data to create a tagged image file format (TIFF) and then converting it into a raster with the nutrient concentrations as the value for each grid in the dataset (Marilyn Gambone, GIS Research Specialist, Texas A\&M Agrilife Research Center, personal communication 9 July 2013). The maps were organized so that the color of the field represents the final concentrations of $\mathrm{N}$ or $\mathrm{P}$, and the label of each sampling point represents the change in concentration from October 2013 to October 2014 at that point. Due to a data collection error, the April 2013 samples were not able to be assigned to a specific point and could not be used for the labels. However, the average concentration for each VTA was calculated for each sampling period and used to track patterns of nutrient accumulation over time. 


\subsection{Statistical Analysis}

Descriptive statistics (mean, median, and standard deviation) for the nutrient concentrations and loads at each of the nine sampler stations were determined. The percent difference between the average concentrations at the VTA inlet and outlet, and similarly with load totals, was calculated to determine the reduction of nutrients occurring within each VTA. To assess whether the calculated reduction was statistically significant, an appropriate hypothesis test was needed. Using R-commander, boxplots were created for graphical analysis of the distribution of each parameter $\left(\mathrm{NO}_{3}-\mathrm{N}, \mathrm{NH}_{4}-\right.$ $\mathrm{N}, \mathrm{PO}_{4}-\mathrm{P}, \mathrm{TN}, \mathrm{TP}$, and runoff), and the Shapiro-Wilk test of normality was conducted as confirmation (Karp, 2014).

The Shapiro-Wilk test returns as its $\mathrm{p}$-value the $\mathrm{R}^{2}$ for the linear regression between the ordered data and their corresponding normal quantiles (Helsel and Hirsch, 2002). The p-values were determined based on the test statistic, $\mathrm{W}$, which was calculated as

$$
\mathrm{W}=\frac{\left(\sum_{\mathrm{i}=1}^{\mathrm{m}} \mathrm{a}_{\mathrm{i}}\left(\mathrm{x}_{\mathrm{n}+1-\mathrm{i}}-\mathrm{x}_{\mathrm{i}}\right)\right)^{2}}{\sum_{\mathrm{i}=1}^{\mathrm{n}}\left(\mathrm{x}_{\mathrm{i}}-\overline{\mathrm{x}}\right)^{2}}
$$

where

$$
\begin{array}{ll}
n & =\text { sample size } \\
m & =\frac{n}{2}, \text { if } \mathrm{n} \text { is even; } \frac{n-1}{2}, \text { if } \mathrm{n} \text { is odd } \\
a_{i} & =\text { Shapiro-Wilk coefficient based on } n \\
\bar{x} & =\text { sample mean }
\end{array}
$$

Results $(\mathrm{p}<0.0003$ for all constituents) indicated data did not fit a normal distribution and therefore, a nonparametric test would have more power than a parametric test to correctly reject $\mathrm{H}_{\mathrm{o}}$ if it was indeed false (Helsel and Hirsch, 2002). Nonparametric tests 
compare median values to determine if there is a significant difference between two independent samples. However, the mean is less resistant to the impact of outliers and more reflective of the entire range of data (Helsel and Hirsch, 2002). Therefore, calculations of the percent reduction between the VTA inlet and outlet were based on mean or total values for concentrations and loads, respectively.

The Wilcoxon Rank-Sum Test was used to test for significant differences in nutrient concentrations among the three sites (VTA In, VTA Out, and Control) at each location (Bell, Brazos, and Robertson Counties). The premise of this test is that if two independent samples (sample sizes $\mathrm{n}$ and $\mathrm{m}, \mathrm{n}<\mathrm{m}$ ) come from the same population, the probability of an observation from one sample being greater than an observation from the other is around $50 \%\left(\mathrm{H}_{0}: \operatorname{Prob}[\mathrm{x}>\mathrm{y}]=0.5\right)($ Helsel and Hirsch, 2002). The combined data from both samples were assigned ranks $\left(R_{k}=1\right.$ to $\left.N, N=n+m\right)$ and the sum of ranks for the smaller data set $\left(\sum_{\mathrm{i}=1}^{\mathrm{n}} \mathrm{R}\right)$ was used as the test statistic, W (Helsel and Hirsch, 2002). R-commander returned a p-value indicating the probability of $\mathrm{W}$ being different than what was calculated, based on the two sample sizes, if $\mathrm{H}_{\mathrm{o}}$ was indeed true and $\mathrm{H}_{\mathrm{o}}$ was rejected if $\mathrm{p}<\alpha$ (Karp, 2014). A commonly used significance level of $\alpha=$ 0.05 was used for all hypothesis tests in this study.

Sites that did not collect a sample for an event were listed as having zero load of all constituents if another site at that location did collect a sample for that same event. While it can be argued that some flow may have occurred at a site even if a sample was not collected, there was no concentration to estimate a value to assign as a replacement for non-detects. Any flow below the sampler's enable level and less than the volume of 
the first flow interval was not captured for any of the events; therefore, assigning a zero value to a site with no sample was within reason for the purposes of load comparison. With a recorded value at each site and for each event, a matched pair test, such as the Sign Test, could be conducted to look for significant differences between the median loads while also helping to cancel out noise from the event-to-event variability by looking at differences between the paired observations (Helsel and Hirsch, 2002).

Similar to the Wilcoxon Rank-Sum test, the Sign Test also assumed that if $\mathrm{x}$ and y were from the same population, Prob $[x>y]=0.5\left(H_{o}\right)($ Helsel and Hirsch, 2002). This was tested by examining differences between data pairs, $\left(D_{i}=x_{i}-y_{i}\right)$ and assigning $\mathrm{a}+$ for $\mathrm{D}_{\mathrm{i}}>0$ and $\mathrm{a}-$ for $\mathrm{D}_{\mathrm{i}}<0$. If $\mathrm{H}_{\mathrm{o}}$ was true, the total number of +'s $\left(\mathrm{S}^{+}\right)$should be approximately equal to $\frac{\mathrm{n}}{2}$, with $\mathrm{n}=$ number of $\mathrm{D}_{\mathrm{i}}$ excluding instances where $\mathrm{D}_{\mathrm{i}}=0$ (Helsel and Hirsch, 2002). The p-value for a one-sided test $\left(H_{a}:\right.$ Prob $\left.[x>y]>0.5\right)$ was the cumulative probability, based on a binomial distribution, that $\mathrm{S}^{+}$would be greater than or equal to what it was if $\mathrm{H}_{\mathrm{o}}$ were indeed true (Helsel and Hirsch, 2002). For a twosided test $\left(H_{a}:\right.$ Prob $\left.[x>y] \neq 0.5\right)$, the $p$-value was doubled and $H_{o}$ was rejected if that $p$ $<\alpha=0.05$. 


\section{RESULTS AND DISCUSSION}

\subsection{Water Quality Analysis}

\subsubsection{Results}

\subsubsection{Bell County}

Boxplots of the Bell County concentration and load data are shown in Figures 6 and 7 , respectively. There was a $31 \%-91 \%$ reduction in mean nutrient concentrations and $>83 \%$ decrease in total nutrient event loads between the VTA inlet and outlet (Table 3). Ideal VTA performance would be indicated by a significant $(\mathrm{p}<0.05)$ difference between VTA In and VTA Out but no significant difference between VTA Out and the control site measurements. Those results were shown in the $\mathrm{NH}_{4}-\mathrm{N}$ and $\mathrm{TP}$ concentrations and for all loads except $\mathrm{NO}_{3}-\mathrm{N}$. This was consistent with previous studies showing that VTAs can significantly reduce $\mathrm{NH}_{4}-\mathrm{N}, \mathrm{PO}_{4}-\mathrm{P}, \mathrm{TN}$, and TP concentrations $(>70 \%)$ but provide less reduction, and often an increase, of $\mathrm{NO}_{3}-\mathrm{N}$ compared to other forms of $\mathrm{N}$ and other nutrients (Chaubey et al., 1994; Edwards et al., 1983; Koelsch et al., 2006). Barker and Young (1984) showed that even in cases where $\mathrm{NO}_{3}-\mathrm{N}$ concentrations increase, runoff retention can enhance the ability of VTAs to decrease nutrient loads. This was reflected in the substantially higher decrease in $\mathrm{NO}_{3}-\mathrm{N}$ load $(83 \%)$ compared to the concentration reduction (31\%), and similarly for the other constituents, which is likely attributable to the $55 \%$ decrease in runoff. 


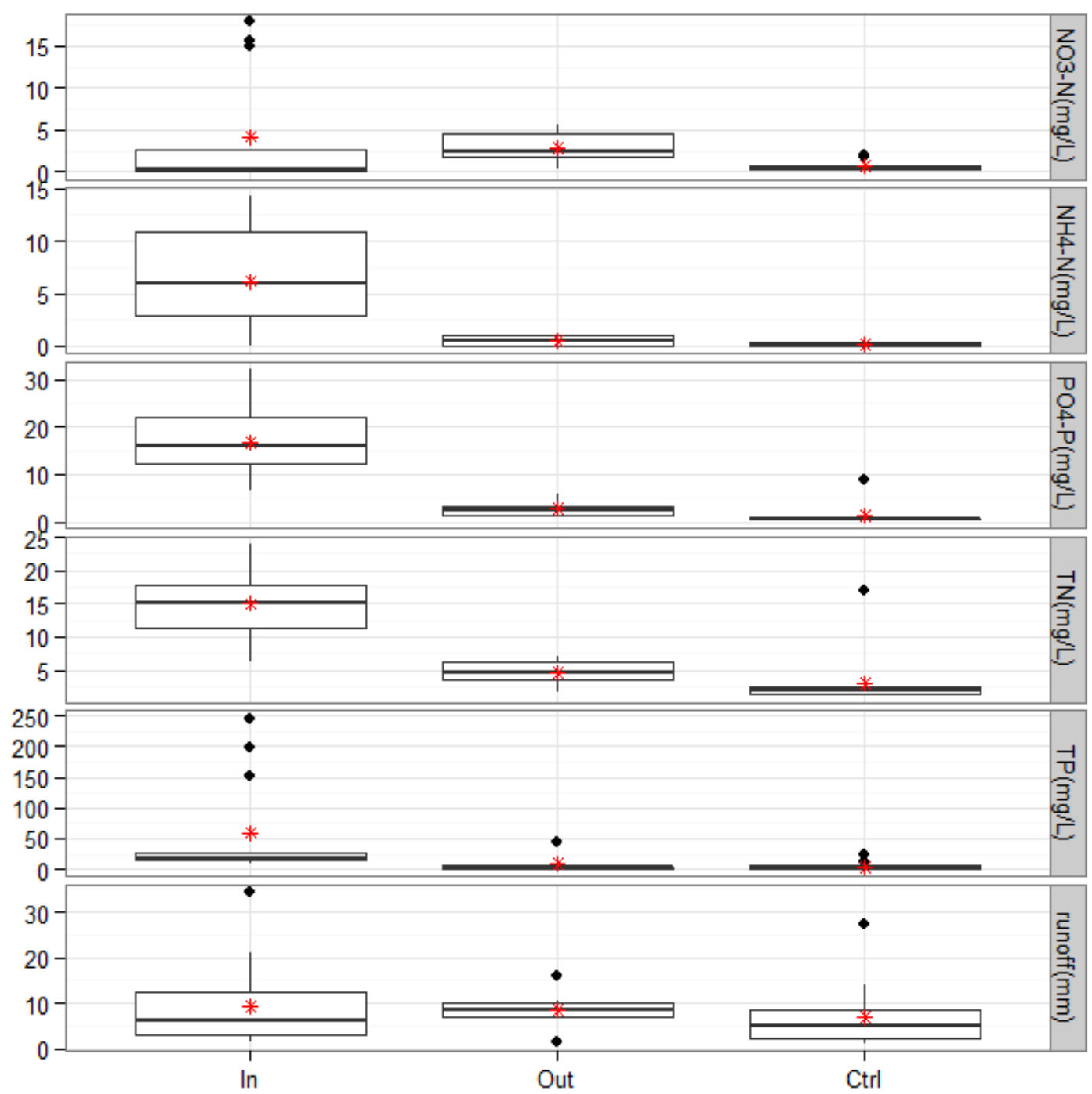

Figure 6. Boxplots of Bell County concentration data. Red asterisks (*) show locations of sample means. 


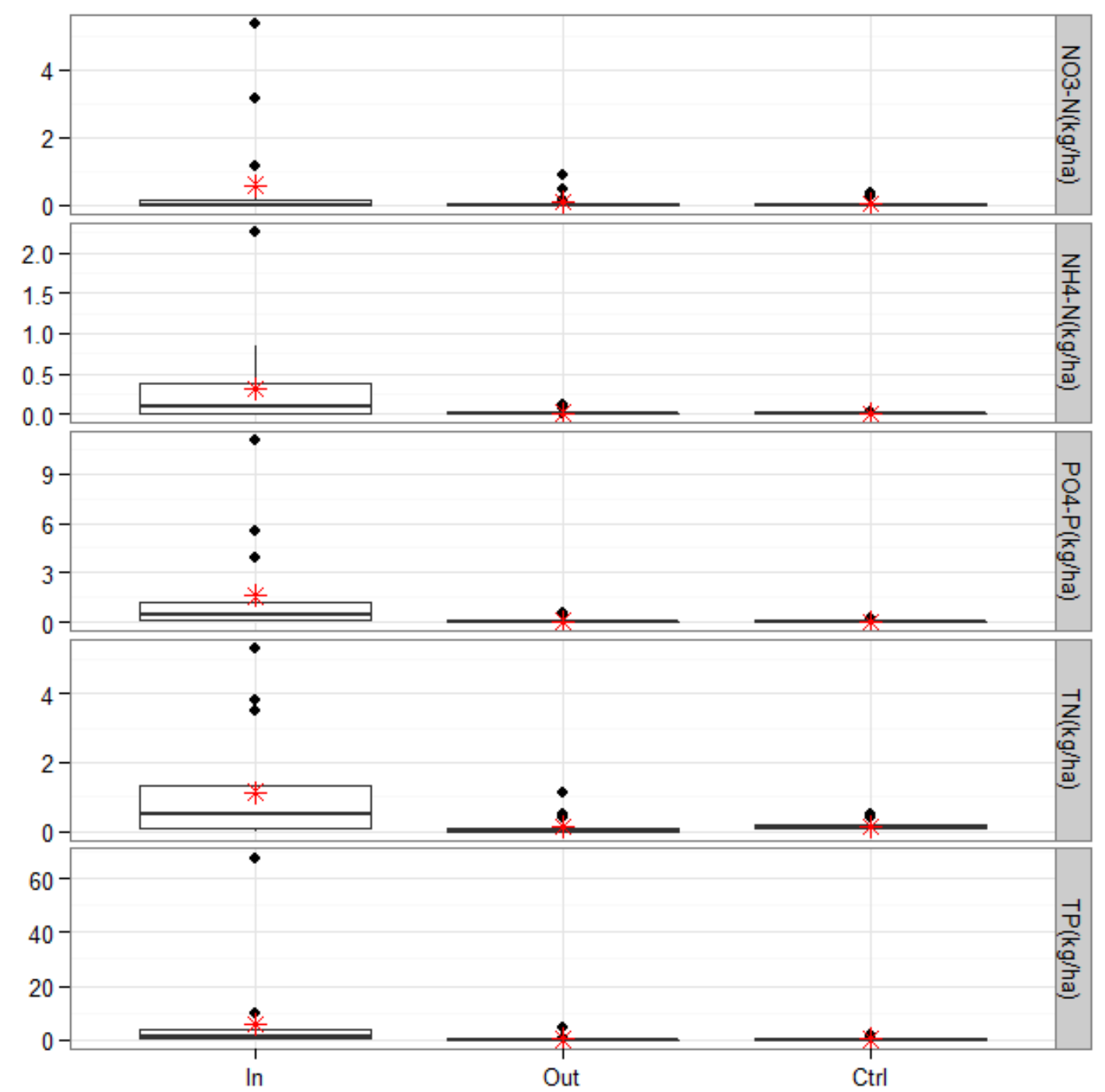

Figure 7. Boxplots of Bell County event load data. Red asterisks (*) show locations of sample means. 
Table 3. Summary of Bell County water quality data ${ }^{[\mathrm{a}]}$

\begin{tabular}{|c|c|c|c|c|c|c|c|c|c|c|}
\hline Nutrient & Statistic & $\begin{array}{c}\text { VTA } \\
\text { In }\end{array}$ & $\begin{array}{l}\text { VTA } \\
\text { Out }\end{array}$ & $\mathrm{Ctrl}$ & $\% \operatorname{Red}^{[\mathrm{d}]}$ & Statistic & $\begin{array}{c}\text { VTA } \\
\text { In }\end{array}$ & $\begin{array}{l}\text { VTA } \\
\text { Out }\end{array}$ & Ctrl & $\% \operatorname{Red}^{[\mathrm{d}]}$ \\
\hline & & 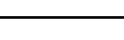 & -mg & & & & & $-\mathrm{k}$ & 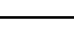 & 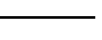 \\
\hline \multirow[t]{2}{*}{$\mathrm{NO}_{3}-\mathrm{N}$} & $\operatorname{Mean}(\mathrm{SD})^{[\mathrm{b}]}$ & $4.2(6.9)$ & $2.9(2.0)$ & $0.6(0.6)$ & \multirow{2}{*}{$31 \%$} & Total & 10.2 & 1.7 & 1.1 & \multirow{2}{*}{$83 \%$} \\
\hline & Median $^{[c]}$ & $0.2 \mathrm{ab}$ & $2.4 \mathrm{a}$ & $0.6 \mathrm{~b}$ & & $\operatorname{Median}^{[c]}$ & $0.0 \mathrm{a}$ & $0.0 \mathrm{a}$ & $0.0 \mathrm{a}$ & \\
\hline \multirow[t]{2}{*}{$\mathrm{NH}_{4}-\mathrm{N}$} & $\operatorname{Mean}(\mathrm{SD})^{[\mathrm{b}]}$ & $6.2(4.9)$ & $0.5(0.5)$ & $0.2(0.2)$ & \multirow{2}{*}{$91 \%$} & Total & 5.3 & 0.2 & 0.1 & \multirow{2}{*}{$96 \%$} \\
\hline & $\operatorname{Median}^{[\mathrm{c}]}$ & $5.9 \mathrm{a}$ & $0.5 \mathrm{~b}$ & $0.2 \mathrm{~b}$ & & $\operatorname{Median}^{[c]}$ & $0.1 \mathrm{a}$ & $0.0 \mathrm{~b}$ & $0.0 \mathrm{~b}$ & \\
\hline \multirow[t]{2}{*}{$\mathrm{PO}_{4}-\mathrm{P}$} & $\operatorname{Mean}(\mathrm{SD})^{[\mathrm{b}]}$ & $16.7(7.6)$ & $2.8(1.7)$ & $1.2(2.1)$ & \multirow{2}{*}{$83 \%$} & Total & 27.2 & 1.5 & 0.8 & \multirow{2}{*}{$95 \%$} \\
\hline & $\operatorname{Median}^{[c]}$ & $16.0 \mathrm{a}$ & $2.3 \mathrm{~b}$ & $0.8 \mathrm{c}$ & & $\operatorname{Median}^{[c]}$ & $0.5 \mathrm{a}$ & $0.0 \mathrm{~b}$ & $0.0 \mathrm{~b}$ & \\
\hline \multirow[t]{2}{*}{$\mathrm{TN}$} & $\operatorname{Mean}(\mathrm{SD})^{[\mathrm{b}]}$ & $15.0(5.0)$ & $4.6(2.0)$ & $2.9(3.9)$ & \multirow{2}{*}{$69 \%$} & Total & 19.3 & 2.5 & 2.2 & \multirow{2}{*}{$87 \%$} \\
\hline & Median $^{[c]}$ & $15.2 \mathrm{a}$ & $4.7 \mathrm{~b}$ & $2.0 \mathrm{c}$ & & $\operatorname{Median}^{[c]}$ & $0.5 \mathrm{a}$ & $0.0 \mathrm{~b}$ & $0.1 \mathrm{~b}$ & \\
\hline \multirow[t]{2}{*}{$\mathrm{TP}$} & $\operatorname{Mean}(S D)^{[b]}$ & $59.8(81.5)$ & $9.5(17.1)$ & $4.0(6.1)$ & \multirow{2}{*}{$84 \%$} & Total & 97.8 & 5.3 & 3.9 & \multirow{2}{*}{$95 \%$} \\
\hline & Median $^{[c]}$ & $18.7 \mathrm{a}$ & $2.8 \mathrm{~b}$ & $0.9 \mathrm{~b}$ & & $\operatorname{Median}^{[\mathrm{c}]}$ & $0.9 \mathrm{a}$ & $0.0 \mathrm{~b}$ & $0.0 \mathrm{~b}$ & \\
\hline & & & & & & $\mathrm{mm}$ & & & & \\
\hline runoff & $\operatorname{Mean}(S D)^{[b]}$ & 7.6(9.0) & $3.4(5.0)$ & $6.5(6.9)$ & $55 \%$ & Total & 129.0 & 58.2 & 116.6 & $55 \%$ \\
\hline
\end{tabular}

${ }^{[\mathrm{a}]}$ Number of events per site: VTA In $=13$, VTA Out $=6, \mathrm{Ctrl}=15$

${ }^{[b]}$ Mean and standard deviation are reported

${ }^{[c]}$ Within the same row, values followed by the same letter are not significantly different $(\mathrm{p}<0.05)$ according to Wilcoxon Rank-Sum and Sign tests for concentrations and loads, respectively

[d] \%Red = Percent reduction from VTA In to VTA Out; based on mean for concentrations and total for loads; negative values indicate an increase

\subsubsection{Brazos County}

At the Brazos County location, the VTA reduced nutrient concentrations by an average of $42 \%-88 \%$, and decreased total event loads 50\% - 88\% (Figures 8 and 9, Table 4). Again, following trends seen in previous studies, $\mathrm{NO}_{3}-\mathrm{N}$ was the only nutrient with no significant difference in the median concentration or load of VTA influent and effluent (Chaubey et al., 1994; Edwards et al., 1983; Koelsch et al., 2006). The difference between measurements at the control site and VTA outlet was statistically significant for all constituents except $\mathrm{NO}_{3}-\mathrm{N}$ concentration, which was similar for all three sites, and TP load, which was the only constituent to exhibit ideal VTA 
performance. There was less runoff reduction (19\%) compared to Bell County but total nutrient loads were still more greatly reduced than the corresponding concentrations.

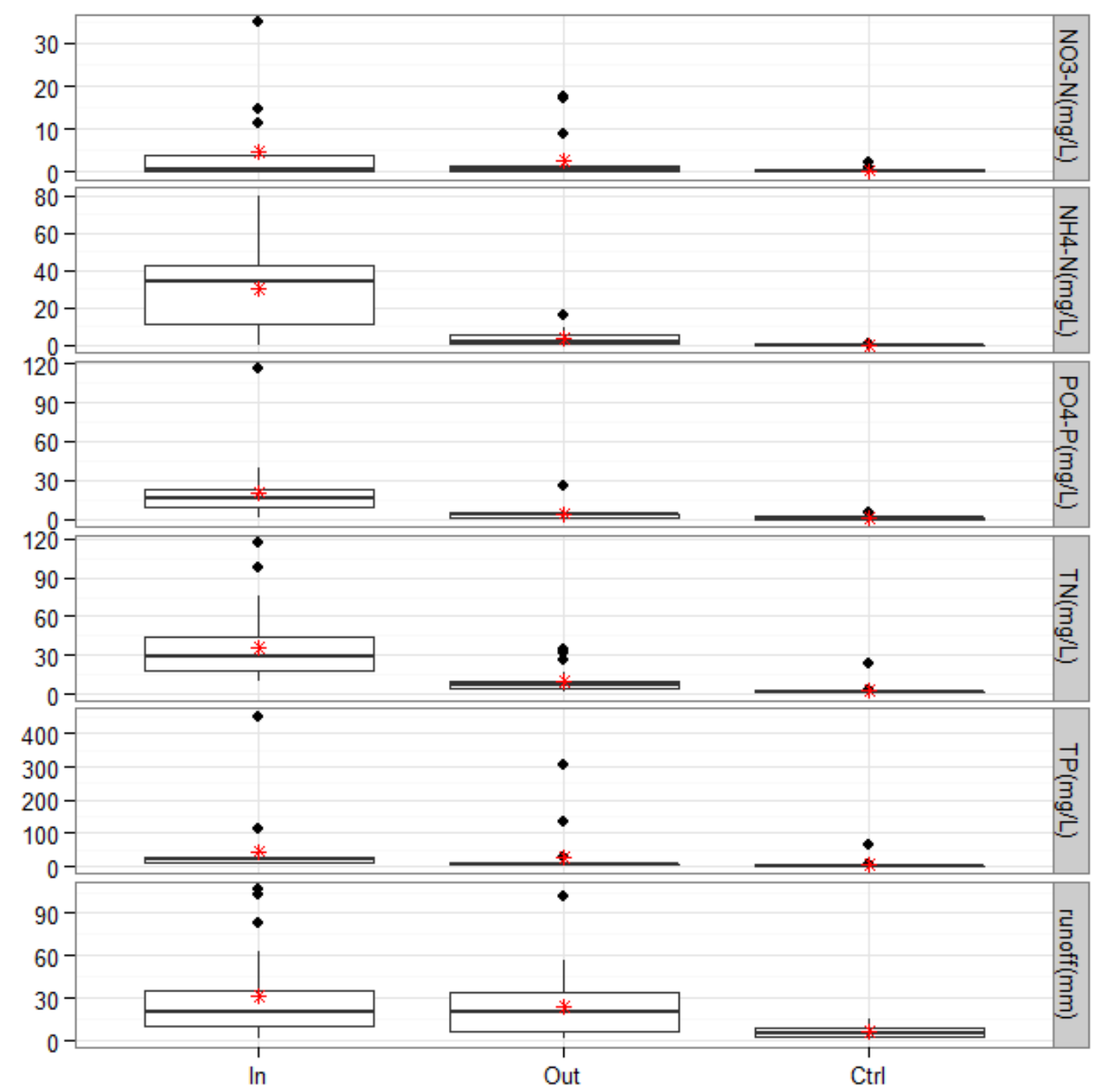

Figure 8. Boxplots of Brazos County concentration data. Red asterisks (*) show locations of sample means. 


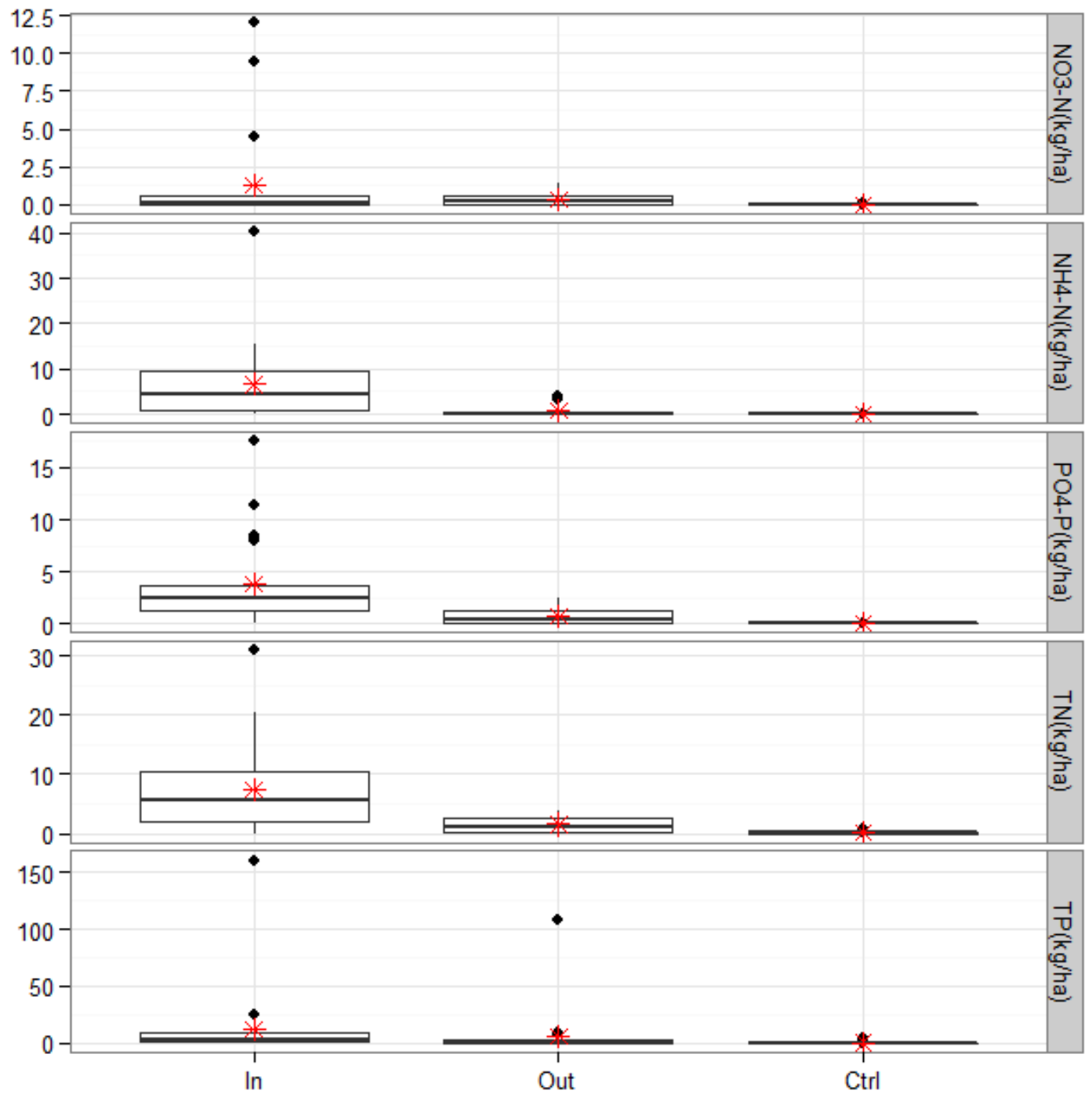

Figure 9. Boxplots of Brazos County event load data. Red asterisks (*) show locations of sample means. 
Table 4. Summary of Brazos County water quality data ${ }^{[\mathrm{a}]}$

\begin{tabular}{|c|c|c|c|c|c|c|c|c|c|c|}
\hline Nutrient & Statistic & $\begin{array}{c}\text { VTA } \\
\text { In }\end{array}$ & $\begin{array}{l}\text { VTA } \\
\text { Out }\end{array}$ & Ctrl & $\% \operatorname{Red}^{[\mathrm{d}]}$ & Statistic & $\begin{array}{c}\text { VTA } \\
\text { In }\end{array}$ & $\begin{array}{l}\text { VTA } \\
\text { Out }\end{array}$ & Ctrl & $\% \operatorname{Red}^{[\mathrm{d}]}$ \\
\hline \multirow{3}{*}{$\mathrm{NO}_{3}-\mathrm{N}$} & & 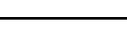 & mg/ & & 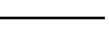 & & 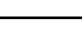 & - $\mathrm{kg}$ & & \\
\hline & $\operatorname{Mean}(\mathrm{SD})^{[\mathrm{b}]}$ & $4.7(8.6)$ & $2.7(5.2)$ & $0.3(0.6)$ & \multirow{2}{*}{$42 \%$} & Total & 30.1 & 7.9 & 0.3 & \multirow{2}{*}{$74 \%$} \\
\hline & Median $^{[\mathrm{c}]}$ & $0.3 \mathrm{a}$ & $0.7 \mathrm{a}$ & $0.1 \mathrm{a}$ & & $\operatorname{Median}^{[\mathrm{c}]}$ & $0.1 \mathrm{a}$ & $0.2 \mathrm{a}$ & $0.0 \mathrm{~b}$ & \\
\hline \multirow[t]{2}{*}{$\mathrm{NH}_{4}-\mathrm{N}$} & $\operatorname{Mean}(\mathrm{SD})^{[\mathrm{b}]}$ & $30.5(24.7)$ & $3.6(4.2)$ & $0.2(0.2)$ & \multirow{2}{*}{$88 \%$} & Total & 151.5 & 18.1 & 0.2 & \multirow{2}{*}{$88 \%$} \\
\hline & $\operatorname{Median}^{[\mathrm{c}]}$ & $33.7 \mathrm{a}$ & $2.1 \mathrm{~b}$ & $0.1 \mathrm{c}$ & & $\operatorname{Median}^{[\mathrm{c}]}$ & $4.3 \mathrm{a}$ & $0.2 \mathrm{~b}$ & $0.0 \mathrm{c}$ & \\
\hline \multirow[t]{2}{*}{$\mathrm{PO}_{4}-\mathrm{P}$} & $\operatorname{Mean}(\mathrm{SD})^{[\mathrm{b}]}$ & $20.9(23.7)$ & $4.5(5.4)$ & $0.7(1.0)$ & \multirow{2}{*}{$79 \%$} & Total & 87.9 & 17.1 & 0.6 & \multirow{2}{*}{$81 \%$} \\
\hline & $\operatorname{Median}^{[\mathrm{c}]}$ & $15.7 \mathrm{a}$ & $3.2 \mathrm{~b}$ & $0.4 \mathrm{c}$ & & $\operatorname{Median}^{[\mathrm{c}]}$ & $2.5 \mathrm{a}$ & $0.4 b$ & $0.0 \mathrm{c}$ & \\
\hline \multirow[t]{2}{*}{$\mathrm{TN}$} & $\operatorname{Mean}(\mathrm{SD})^{[\mathrm{b}]}$ & $36.2(28.5)$ & $9.9(9.5)$ & $3.0(5.5)$ & \multirow{2}{*}{$73 \%$} & Total & 169.1 & 35.2 & 2.3 & \multirow{2}{*}{$79 \%$} \\
\hline & $\operatorname{Median}^{[\mathrm{c}]}$ & $28.7 \mathrm{a}$ & $6.9 \mathrm{~b}$ & $1.6 \mathrm{c}$ & & Median $^{[\mathrm{c}]}$ & $5.7 \mathrm{a}$ & $1.1 \mathrm{~b}$ & $0.1 \mathrm{c}$ & \\
\hline \multirow[t]{2}{*}{$\mathrm{TP}$} & $\operatorname{Mean}(\mathrm{SD})^{[\mathrm{b}]}$ & 47.2(95.6) & 26.1(69.7) & $5.1(15.2)$ & \multirow{2}{*}{$45 \%$} & Total & 283.0 & 141.5 & 5.7 & \multirow{2}{*}{$50 \%$} \\
\hline & Median $^{[\mathrm{c}]}$ & $21.4 \mathrm{a}$ & $4.7 b$ & $0.6 \mathrm{c}$ & & $\operatorname{Median}^{[\mathrm{c}]}$ & $3.9 \mathrm{a}$ & $1.1 \mathrm{~b}$ & $0.0 \mathrm{~b}$ & \\
\hline runoff & $\operatorname{Mean}(\mathrm{SD})^{[\mathrm{b}]}$ & $27.6(30.8)$ & $22.2(24.4)$ & $4.6(4.6)$ & $19 \%$ & Total & 689.6 & 556.1 & 115.3 & $19 \%$ \\
\hline
\end{tabular}

${ }^{[a]}$ Number of events per site: VTA In $=21$, VTA Out $=21, \mathrm{Ctrl}=17$

${ }^{[b]}$ Mean and standard deviation are reported

${ }^{[c]}$ Within the same row, values followed by the same letter are not significantly different $(\mathrm{p}<0.05)$ according to Wilcoxon Rank-Sum and Sign tests for concentrations and loads, respectively

[d] \%Red = Percent reduction from VTA In to VTA Out; based on mean for concentrations and total for loads; negative values indicate an increase

\subsubsection{Robertson County}

The Robertson County VTA decreased mean nutrient concentrations by $24 \%$ $87 \%$ on average, and reduced the total loads by $58 \%-85 \%$ (Figures 10 and 11, Table 5). Possibly due to the very small source, this was the only site where the median $\mathrm{NO}_{3}-\mathrm{N}$ load at VTA Out was significantly lower than that at VTA In. The median $\mathrm{PO}_{4}-\mathrm{P}$ load and concentration and the TN and TP median loads were also significantly decreased by the VTA. Statistically, ideal results were seen in $\mathrm{PO}_{4}-\mathrm{P}$ concentration and load, as well as $\mathrm{NO}_{3}-\mathrm{N}$ load, which is contrary to previously mentioned studies and results from other locations showing low VTA performance with regards to $\mathrm{NO}_{3}-\mathrm{N}$. Possible explanations for this departure will be discussed in the following section. 


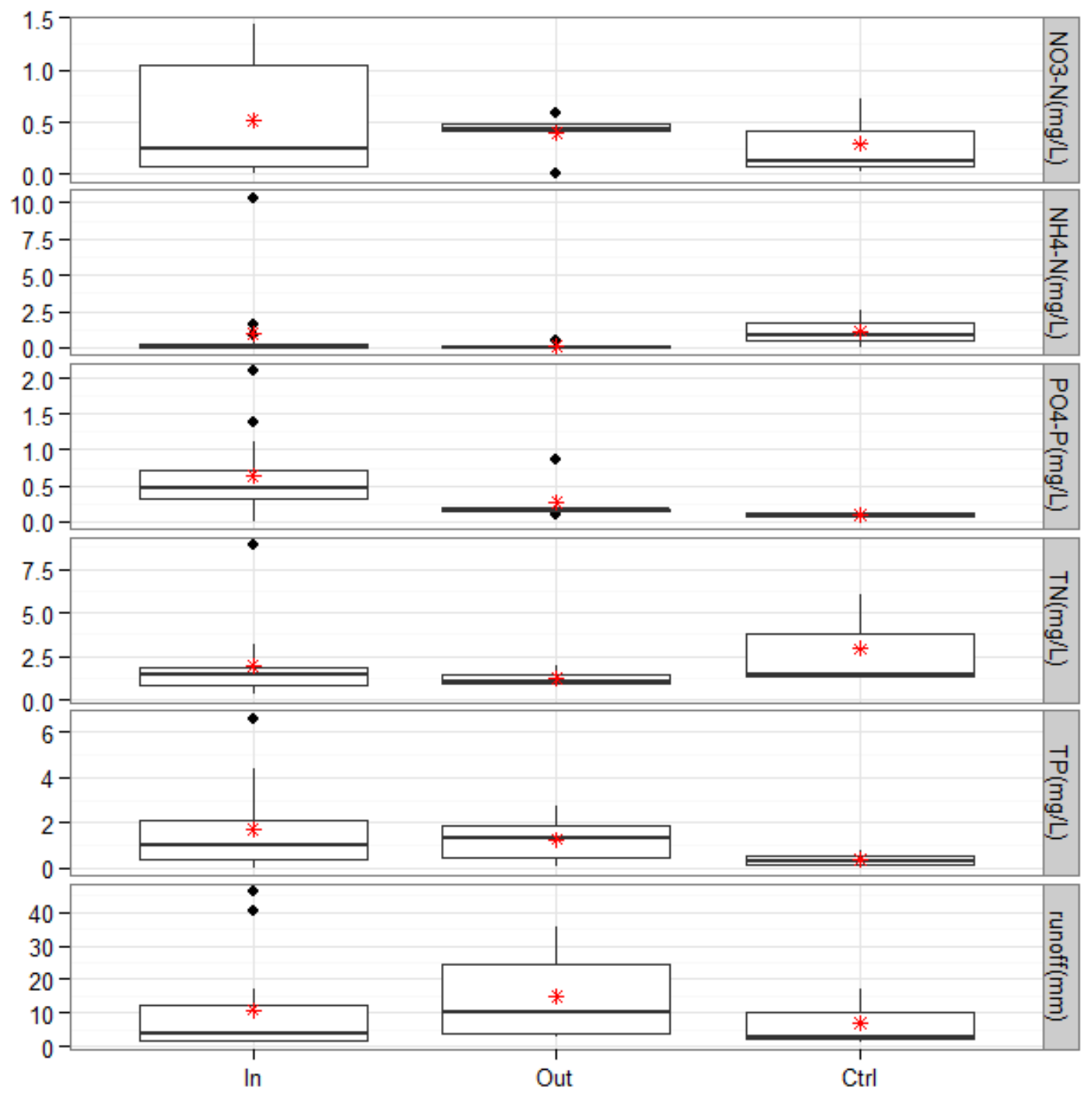

Figure 10. Boxplots of Robertson County concentration data. Red asterisks $\left(^{*}\right)$ show locations of sample means. 


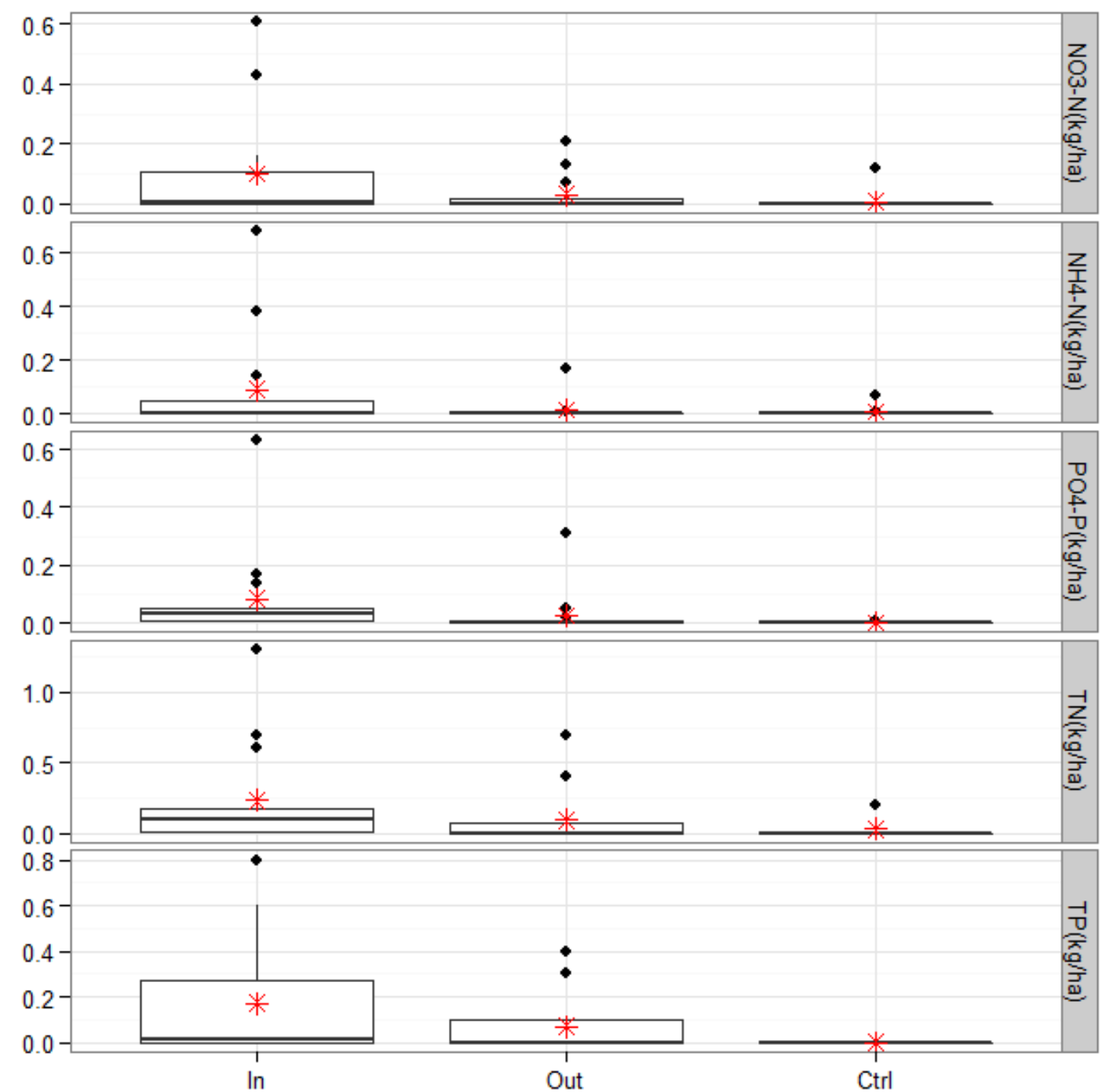

Figure 11. Boxplots of Robertson County event load data. Red asterisks $\left(^{*}\right)$ show locations of sample means. 
Table 5. Summary of Robertson County water quality data ${ }^{[\mathrm{a}]}$

\begin{tabular}{|c|c|c|c|c|c|c|c|c|c|c|}
\hline Nutrient & Statistic & $\begin{array}{c}\text { VTA } \\
\text { In }\end{array}$ & $\begin{array}{c}\text { VTA } \\
\text { Out }\end{array}$ & Ctrl & $\% \operatorname{Red}^{[\mathrm{d}]}$ & Statistic & $\begin{array}{c}\text { VTA } \\
\text { In } \\
\end{array}$ & $\begin{array}{c}\text { VTA } \\
\text { Out } \\
\end{array}$ & Ctrl & $\% \operatorname{Red}^{[\mathrm{d}]}$ \\
\hline \multirow{3}{*}{$\mathrm{NO}_{3}-\mathrm{N}$} & & 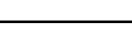 & $\mathrm{mg}$ & & & & 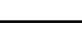 & $\mathrm{kg}$ & & 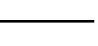 \\
\hline & $\operatorname{Mean}(\mathrm{SD})^{[\mathrm{b}]}$ & $0.5(0.6)$ & $0.4(0.2)$ & $0.3(0.4)$ & \multirow{2}{*}{$24 \%$} & Total & 1.4 & 0.4 & 0.1 & \multirow{2}{*}{$70 \%$} \\
\hline & $\operatorname{Median}^{[\mathrm{c}]}$ & $0.3 \mathrm{a}$ & $0.4 \mathrm{a}$ & $0.1 \mathrm{a}$ & & $\operatorname{Median}^{[\mathrm{c}]}$ & $0.0 \mathrm{a}$ & $0.0 \mathrm{~b}$ & $0.0 \mathrm{~b}$ & \\
\hline \multirow[t]{2}{*}{$\mathrm{NH}_{4}-\mathrm{N}$} & $\operatorname{Mean}(\mathrm{SD})^{[\mathrm{b}]}$ & $1.0(2.7)$ & $0.1(0.2)$ & $1.1(1.3)$ & \multirow{2}{*}{$87 \%$} & Total & 1.3 & 0.2 & 0.1 & \multirow{2}{*}{$85 \%$} \\
\hline & $\operatorname{Median}^{[\mathrm{c}]}$ & $0.1 \mathrm{a}$ & $0.0 \mathrm{a}$ & $0.8 \mathrm{a}$ & & $\operatorname{Median}^{[\mathrm{c}]}$ & $0.0 \mathrm{a}$ & $0.0 \mathrm{a}$ & $0.0 \mathrm{a}$ & \\
\hline \multirow[t]{2}{*}{$\mathrm{PO}_{4}-\mathrm{P}$} & $\operatorname{Mean}(\mathrm{SD})^{[\mathrm{b}]}$ & $0.6(0.6)$ & $0.3(0.3)$ & $0.1(0.1)$ & \multirow{2}{*}{$59 \%$} & Total & 1.2 & 0.4 & 0.0 & \multirow{2}{*}{$67 \%$} \\
\hline & $\operatorname{Median}^{[\mathrm{c}]}$ & $0.5 \mathrm{a}$ & $0.2 \mathrm{~b}$ & $0.1 \mathrm{~b}$ & & $\operatorname{Median}^{[\mathrm{c}]}$ & $0.0 \mathrm{a}$ & $0.0 \mathrm{~b}$ & $0.0 \mathrm{~b}$ & \\
\hline \multirow[t]{2}{*}{$\mathrm{TN}$} & $\operatorname{Mean}(\mathrm{SD})^{[\mathrm{b}]}$ & $2.0(2.2)$ & $1.2(0.5)$ & $2.9(2.7)$ & \multirow{2}{*}{$38 \%$} & Total & 3.2 & 1.4 & 0.4 & \multirow{2}{*}{$58 \%$} \\
\hline & $\operatorname{Median}^{[\mathrm{c}]}$ & $1.4 \mathrm{a}$ & $1.1 \mathrm{a}$ & $1.5 \mathrm{a}$ & & $\operatorname{Median}^{[\mathrm{c}]}$ & $0.1 \mathrm{a}$ & $0.0 \mathrm{~b}$ & $0.0 \mathrm{c}$ & \\
\hline \multirow[t]{2}{*}{$\mathrm{TP}$} & $\operatorname{Mean}(\mathrm{SD})^{[\mathrm{b}]}$ & $1.7(1.9)$ & $1.3(1.0)$ & $0.3(0.4)$ & \multirow{2}{*}{$25 \%$} & Total & 2.5 & 1.0 & 0.1 & \multirow{2}{*}{$62 \%$} \\
\hline & $\operatorname{Median}^{[\mathrm{c}]}$ & $1.0 \mathrm{a}$ & $1.3 \mathrm{a}$ & $0.3 \mathrm{a}$ & & $\operatorname{Median}^{[\mathrm{c}]}$ & $0.0 \mathrm{a}$ & $0.0 \mathrm{~b}$ & $0.0 \mathrm{c}$ & \\
\hline runoff & $\operatorname{Mean}(\mathrm{SD})^{[\mathrm{b}]}$ & $11.3(14.1)$ & 7.3(11.6) & $1.4(4.4)$ & $35 \%$ & Total & 169.3 & 109.5 & 21.1 & $35 \%$ \\
\hline \multicolumn{11}{|c|}{$\begin{array}{l}\text { [a] Number of events per site: VTA In }=13 \text {, VTA Out }=6, \text { Ctrl }=3 \\
{ }^{[b]} \text { Mean and standard deviation are reported } \\
{ }^{[c]} \text { Within the same row, values followed by the same letter are not significantly different }(\mathrm{p}<0.05) \text { according to } \\
\text { Wilcoxon Rank-Sum and Sign tests for concentrations and loads, respectively } \\
\text { [d] } \% \text { Red = Percent reduction from VTA In to VTA Out; based on mean for concentrations and total for loads; } \\
\text { negative values indicate an increase }\end{array}$} \\
\hline
\end{tabular}

\subsubsection{Discussion}

\subsubsection{VTA Performance}

A portion of the organic pool of $\mathrm{N}$ in swine manure was mineralized into $\mathrm{NH}_{3}$,

$\mathrm{NH}_{4}{ }^{+}$, and $\mathrm{NO}_{3}{ }^{-}$, but with the lack of a sufficiently anaerobic environment for

denitrification to occur, the $\mathrm{NO}_{3}{ }^{-}$accumulated instead of being converted into gaseous

forms of $\mathrm{N}$ and released from the soil (Espinoza et al., 2005). This is one possible

explanation for why $\mathrm{NO}_{3}-\mathrm{N}$ was typically the nutrient decreased the least by the VTA in

this and other studies (Koelsch et al., 2006). At the Robertson County location,

however, a seasonally high water table was observed in the area of the field near the

control site and VTA outlet during a particularly rainy time of the study period. These 
conditions may have been more appropriate for denitrification and can help explain why there was a larger decrease in $\mathrm{NO}_{3}-\mathrm{N}$ at this location. But even at the other locations, $\mathrm{NO}_{3}-\mathrm{N}$ concentrations in VTA runoff were still lower than the $3-6 \mathrm{mg} / \mathrm{L}$ found in runoff from swine manure spray fields, and substantially lower than the VTA inflow (Westerman et al., 1995). Though there were only a few instances of nutrient levels at the VTA outlet being both significantly lower than the VTA inlet and similar to the control site, nutrient reductions at all locations were comparable to results of previous studies (Barker and Young, 1984; Mankin and Okoren, 2003; Andersen et al., 2013).

In studies where both concentrations and loads were analyzed, the reduction of nutrient loads was typically greater than the concentration reduction, in large part due to the retention of runoff within the VTA (Barker and Young, 1984; Keaton et al., 1998; Hawkins et al., 1999). This trend was generally true for this project; however, Brazos County had the lowest reduction of total runoff but still showed better performance, in most regards, than Robertson County. The additional runoff was possibly from subsurface lateral flow due to a restrictive layer in the soil profile and/or the proximity of the VTA outlet to a farm pond $(<30 \mathrm{~m})$. The lower concentration of nutrients entering the Robertson County VTA and the limitations of contaminant removal mechanisms when acting upon such a small pool of nutrients may have also contributed to these results.

\subsubsection{Impact of Solids Management}

For the Bell County location, a large influx of solids drained directly from the farrowing crate to the VTA inlet during farrowing season and repeatedly clogged the 
bubbler tube. This issue was resolved by installing a pipe to allow the crate drainage to bypass the inlet flume and sampler and empty directly into the VTA. The outlet of the bypass was periodically moved along the top of VTA to distribute the solids across the top of the field. While this did allow for more seamless site management, it also meant that samples were not completely representative of the amount of nutrients entering the VTA. Because of this, the actual nutrient reduction from the Bell County VTA is likely much higher than was reflected in this study.

There was not as much of a solids management issue with the other two locations although there was no solids pre-treatment stage prior to the VTA. Overall, however, the Bell County VTA showed the best performance in reducing nutrient concentrations and loads and in retaining runoff. The recommendation of removing solids from the waste stream prior to it entering the VTA is to prevent damage to vegetation at the top of the VTA that could potentially limit its effectiveness (Koelsch et al., 2006). That the location with the largest solids issue was also the one with the best overall performance implies that the impact of solids accumulation can be overcome by adjusting other design factors, especially at small facilities.

\subsubsection{Influence of Design Factors}

It was expected that site design factors such as VTA area/Source area ratio and VTA area/Animal ratio would help explain differences in nutrient removal (Table 1). Because the data sets were so small, finding a statistically significant relationship between percent reductions and site factors would be virtually impossible. However, a visual examination of the data (Figures $12-14$ ) did not show any obvious trend that 
comported with previous studies demonstrating improved VTA efficiency with increased treatment length and treatment area/source area ratio (Chaubey et al., 1994). Other elements such as nutrient and solids loading, vegetation, soil type, and site management may have masked the influence of factors relating to the VTA size, but more data would be necessary to explore those relationships. Trend analysis of all these components in a larger data set, or some combination thereof, should show increased VTA performance as factors that improve runoff retention and plant uptake also increase (Koelsch et al., 2006).

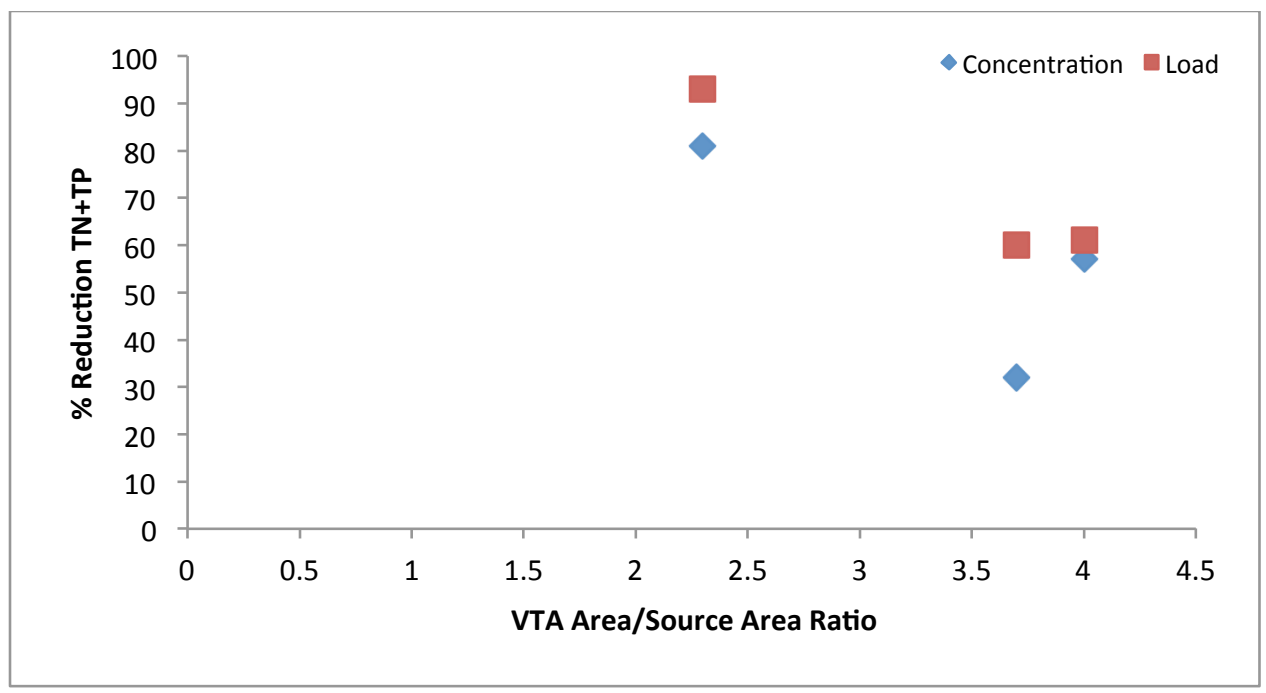

Figure 12. Relationship between VTA Area/Source Area ratio and percent reduction of the sum of TN and TP based on the average concentrations and total loads for all locations. 


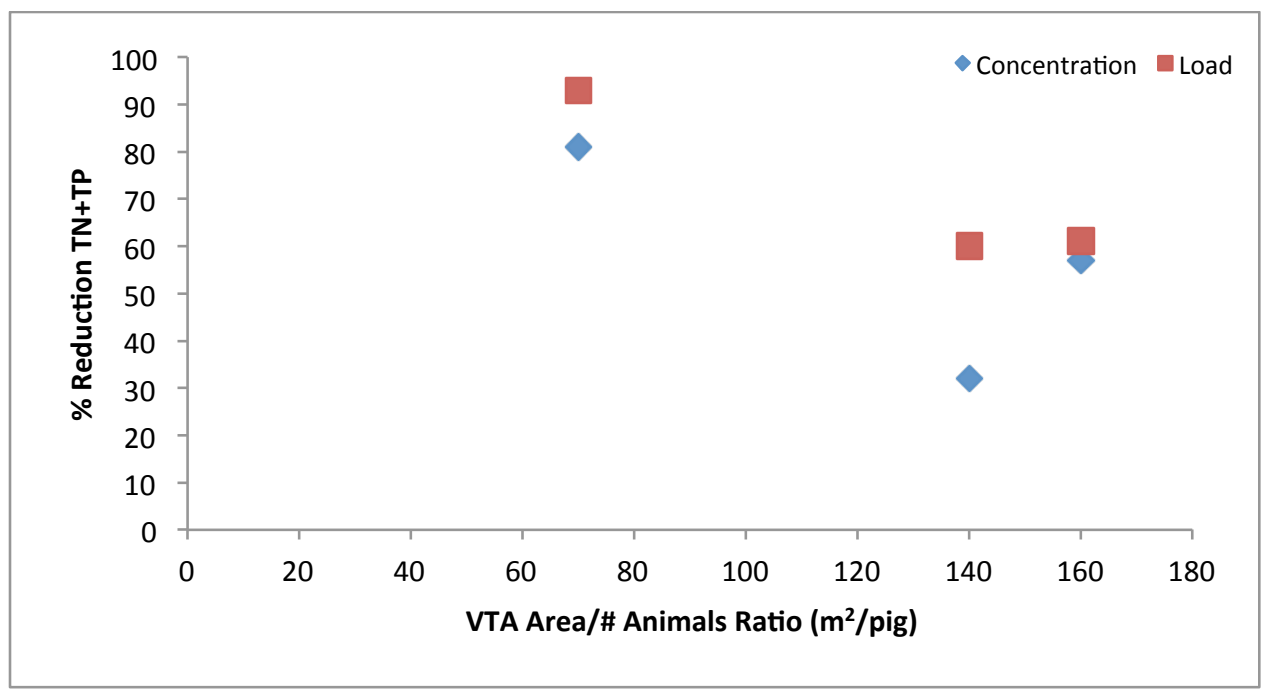

Figure 13. Relationship of VTA Area/\# Animals ratio and percent reduction of the sum of TN and TP based on the average concentrations and total loads for all locations.

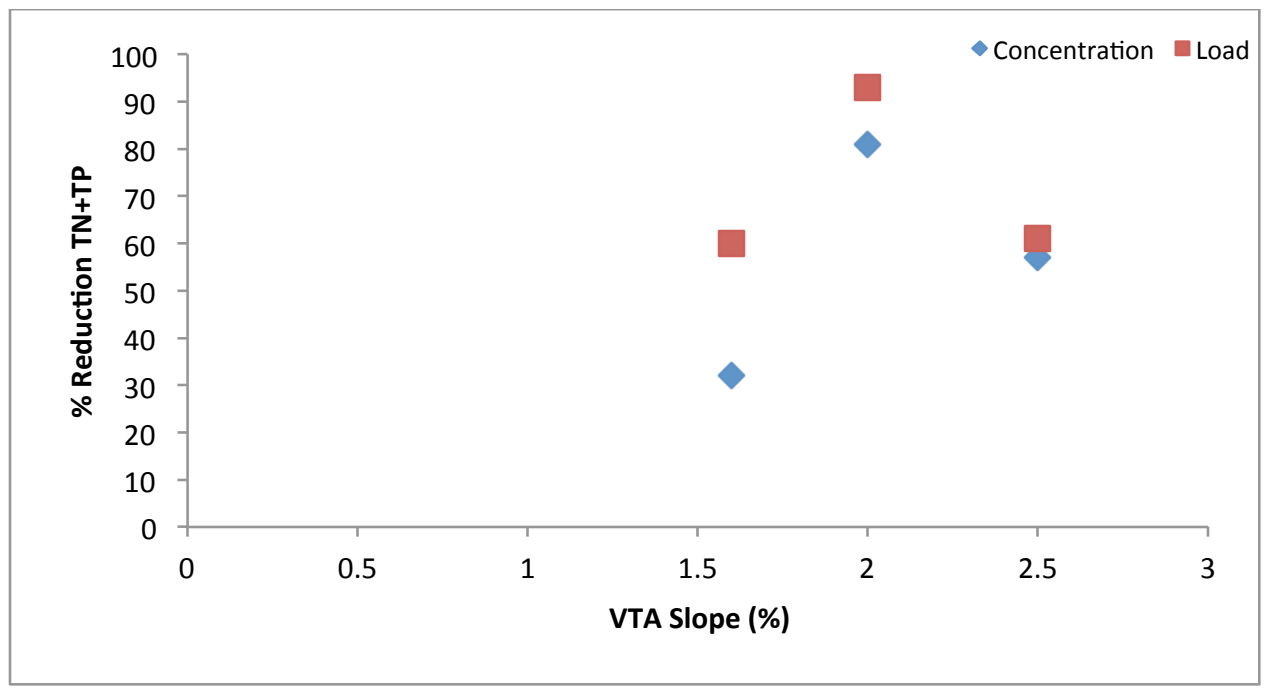

Figure 14. Relationship between VTA Slope and percent reduction of the sum of TN and TP based on the average concentrations and total loads for all locations.

\subsubsection{Uncertainty in Water Quality Results}

With a flow-weighted sampling regimen, accurate measurement of flow is essential to capturing a composite sample representative of the true nutrient flux during 
the storm (Harmel et al., 2006). During the course of this study, there were several occasions where flow measurement was compromised due to flume malfunction, an error in the sampling program, or sampler malfunction. In order to maintain as much data integrity as possible, if samples were collected and analyzed for these instances, the corresponding data was not included in statistical analysis.

A study by Lentz (2011) suggests that, due to the dynamic biological processes that control nutrient cycling, prolonged sample storage may impact the measurement of their dissolved nutrients. In an effort to test more than just a few samples at one time, some samples were held for as long as 3.5 months before nutrient analysis was conducted. Though there is uncertainty in any measurement made, these delays likely increased that error. Samples collected after reading the Lentz study (2011) in July 2014 were tested more rapidly in order to reduce the uncertainty.

Another source of error was the use of the calibration curve to determine the concentrations of samples with analytical responses outside the range of experimentally determined responses of the calibration standards. As previously stated, the linear response/concentration relationship in the Lambert-Beer law is not applicable at high concentrations (SEAL Analytical, 2012a). For more accurate measurement, samples with high analyte content should be diluted or calibration curves should be developed using nonlinear or weighted linear regression methods to account for a wider range of standards (Bonicamp et al., 1999). This information was learned late in the project when there was no remaining sample material and most of the data analysis had already been 
done. As the project continues, future sample analysis will take these issues into consideration.

The cumulative uncertainty in data for a water quality study can be calculated as

$$
E_{P}=\sqrt{\sum_{i=1}^{n}\left(E_{1}^{2}+E_{2}^{2}+\cdots+E_{n}^{2}\right)}
$$

where

$$
\begin{array}{ll}
E_{P} & =\text { probable range of cumulative error }( \pm \%) \\
n & =\text { number of sources of potential error } \\
E_{1}, E_{2}, \ldots, E_{n} & =\text { potential sources of error }( \pm \%)(\text { Harmel et al., 2006) }
\end{array}
$$

Common sources of error, as reported by Harmel et al. (2006), include a range of values for typical, best case, and worst case data collection scenarios based on the conditions of flow monitoring $\left(\mathrm{E}_{\mathrm{Q}}\right)$, sample collection $\left(\mathrm{E}_{\mathrm{C}}\right)$, sample processing and storage $\left(\mathrm{E}_{\mathrm{PS}}\right)$, and laboratory analysis $\left(\mathrm{E}_{\mathrm{LA}}\right)$ processes.

In this study, the low end of the typical range of $E_{Q}( \pm 6 \%)$ was selected because flumes are one of the most accurate flow monitoring devices when they are functioning properly and instances where flow measurement was compromised were removed from the data set (Harmel et al., 2006). Automated samplers also minimize human-introduced error in sample collection, so the minimum of the typical $E_{C}$ range $( \pm 4.6 \%)$ was chosen (Harmel et al., 2006). Overall, laboratory analysis was fairly standard since there were only a few samples impacted by the calibration curve issue; therefore, an average typical $\mathrm{E}_{\mathrm{LA}}$ value $( \pm 12.6 \%)$ was selected (Harmel et al., 2006). The highest typical $\mathrm{E}_{\mathrm{PS}}$ value ( \pm $16 \%)$ was selected for total nutrient data; however, the low end of the worst case- 
scenario $\mathrm{E}_{\mathrm{PS}}$ range $( \pm 34.5 \%)$ was chosen for dissolved nutrient data because the delayed analysis would not necessarily show the same nutrient speciation in the samples as when they were first collected (Harmel et al., 2006; Lentz, 2011). Final cumulative $E_{P}$ was \pm $37 \%$ for $\mathrm{NO}_{3}-\mathrm{N}, \mathrm{NH}_{4}-\mathrm{N}, \mathrm{PO}_{4}-\mathrm{P}$ and $\pm 22 \%$ for $\mathrm{TN}$ and $\mathrm{TP}$.

\subsection{Soil Quality Analysis}

\subsubsection{Results}

Soil test results for Bell, Brazos, and Robertson counties are listed in Tables 6, 7, and 8, respectively. All three locations showed the same overall pattern of an increase in the inorganic N and P between April and October of 2013 and then a continual decrease through October 2014. On average, there was a 16-95\% reduction in soil nutrients between the first and last round of soil tests except in Bell County, which showed a 5\% increase of $\mathrm{N}$ in the surface soil sample.

Maps of the data show that all the final soil samples had low to very low nutrient concentrations, as indicated by the green and light green coloration (Figures $15-20$ ). Between October 2013 and October 2014, there was a decrease of $7.2-282.1 \mathrm{lbs} / \mathrm{ac} \mathrm{N}$ and $0.2-521 \mathrm{lbs} / \mathrm{ac} \mathrm{P}$ at the individual sampling points, with a few notable exceptions. The surface soil sample near the outlet of a flow distribution pipe at the Bell County location showed an increase of $23.6 \mathrm{lbs} / \mathrm{ac} \mathrm{N}$. An increase of $8.3 \mathrm{lbs} / \mathrm{ac} \mathrm{P}$ was seen in the surface sample closest to the VTA inlet in Brazos County. 
Table 6. Bell County soil data

\begin{tabular}{|c|c|c|c|c|c|c|c|c|c|}
\hline \multirow[b]{2}{*}{ Depth } & \multirow[b]{2}{*}{ Sample Site } & \multicolumn{4}{|c|}{ Inorganic $\mathrm{N}(\mathrm{lb} / \mathrm{ac})$} & \multicolumn{4}{|c|}{ Inorganic $\mathrm{P}(\mathrm{lb} / \mathrm{ac})$} \\
\hline & & Apr 2013 & Oct 2013 & Apr 2014 & Oct 2014 & Apr 2013 & Oct 2013 & Apr 2014 & Oct 2014 \\
\hline \multirow[t]{16}{*}{$0-6 "$} & 1 & 6.4 & 21.9 & 25.0 & 45.5 & 10.4 & 47.6 & 102.5 & 18.3 \\
\hline & 2 & 11.5 & 21.2 & 33.5 & 4.8 & 5.3 & 76.1 & 133.5 & 3.1 \\
\hline & 3 & 10.0 & 149.6 & 17.0 & 20.8 & 8.3 & 71.3 & 12.1 & 31.9 \\
\hline & 4 & 5.0 & 27.2 & 6.0 & 4.3 & 4.0 & 3.8 & 1.9 & 1.4 \\
\hline & 5 & 8.6 & 28.2 & 3.9 & 5.5 & 7.8 & 81.1 & 23.7 & 11.5 \\
\hline & 6 & 15.8 & 27.5 & 8.5 & 3.6 & 207.0 & 13.9 & 9.8 & 2.4 \\
\hline & 7 & 6.8 & 20.6 & 5.4 & 4.0 & 29.1 & 11.3 & 5.2 & 1.9 \\
\hline & 8 & 4.6 & 26.8 & 10.2 & 3.6 & 488.9 & 56.1 & 14.3 & 5.6 \\
\hline & 9 & 7.0 & 29.5 & 3.8 & 3.9 & 0.4 & 7.3 & 4.0 & 1.1 \\
\hline & 10 & 8.6 & 42.3 & 2.8 & 3.3 & 8.9 & 2.8 & 0.8 & 1.2 \\
\hline & 11 & 7.3 & 16.6 & 4.9 & 4.2 & 4.8 & 531.0 & 136.5 & 10.0 \\
\hline & 12 & 10.9 & 23.6 & 4.7 & 4.5 & 133.3 & 17.2 & 12.2 & 6.7 \\
\hline & Mean & 8.5 & 36.2 & 10.5 & 9.0 & 75.7 & 76.6 & 38.0 & 7.9 \\
\hline & Max & 15.8 & 149.6 & 33.5 & 45.5 & 488.9 & 531.0 & 136.5 & 31.9 \\
\hline & Min & 4.6 & 16.6 & 2.8 & 3.3 & 0.4 & 2.8 & 0.8 & 1.1 \\
\hline & Overall Change $\mathrm{e}^{[\mathrm{a}]}$ & & & & $5 \%$ & & & & $-90 \%$ \\
\hline
\end{tabular}


Table 6 Continued.

\begin{tabular}{|c|c|c|c|c|c|c|c|c|c|}
\hline \multirow[b]{2}{*}{ Depth } & \multirow[b]{2}{*}{ Sample Site } & \multicolumn{4}{|c|}{ Inorganic N (lb/ac) } & \multicolumn{4}{|c|}{ Inorganic $\mathrm{P}(\mathrm{lb} / \mathrm{ac})$} \\
\hline & & Apr 2013 & Oct 2013 & Apr 2014 & Oct 2014 & Apr 2013 & Oct 2013 & Apr 2014 & Oct 2014 \\
\hline \multirow[t]{16}{*}{$6-12^{\prime \prime}$} & 1 & 5.3 & 19.2 & 11.6 & 4.4 & 4.8 & 2.1 & 7.9 & 1.4 \\
\hline & 2 & 6.7 & 18.0 & 23.6 & 3.1 & 0.6 & 19.9 & 80.2 & 1.0 \\
\hline & 3 & 5.2 & 286.2 & 13.7 & 4.1 & 0.7 & 15.8 & 5.5 & 0.7 \\
\hline & 4 & 4.1 & 14.2 & 6.5 & 2.8 & 0.4 & 1.8 & 2.4 & 0.9 \\
\hline & 5 & 7.3 & 12.6 & 4.5 & 3.0 & 2.2 & 31.9 & 25.3 & 2.2 \\
\hline & 6 & 8.2 & 14.9 & 3.2 & 3.5 & 24.3 & 1.7 & 2.4 & 1.2 \\
\hline & 7 & 5.4 & 15.7 & 2.9 & 3.8 & 0.6 & 5.1 & 1.6 & 1.3 \\
\hline & 8 & 4.9 & 18.0 & 3.7 & 2.5 & 195.3 & 42.5 & 2.8 & 2.3 \\
\hline & 9 & 4.5 & 19.5 & 15.1 & 5.9 & 0.6 & 4.5 & 4.9 & 1.1 \\
\hline & 10 & 5.3 & 21.7 & 1.4 & 3.0 & 1.3 & 1.7 & 0.5 & 1.1 \\
\hline & 11 & 6.1 & 13.8 & 4.8 & 2.9 & 0.5 & 224.0 & 109.5 & 65.6 \\
\hline & 12 & 9.5 & 17.2 & 3.5 & 4.8 & 63.7 & 11.3 & 2.1 & 2.0 \\
\hline & Mean & 6.0 & 39.3 & 7.9 & 3.7 & 24.6 & 30.2 & 20.4 & 6.7 \\
\hline & Max & 9.5 & 286.2 & 23.6 & 5.9 & 195.3 & 224.0 & 109.5 & 65.6 \\
\hline & Min & 4.1 & 12.6 & 1.4 & 2.5 & 0.4 & 1.7 & 0.5 & 0.7 \\
\hline & Overall Change ${ }^{[\mathrm{a}]}$ & & & & $-39 \%$ & & & & $-73 \%$ \\
\hline
\end{tabular}

${ }^{[a]}$ Overall change reflects the percent difference between Apr 2013 and Oct 2014 sample sets based on the mean. 
Table 7. Brazos County soil data

\begin{tabular}{|c|c|c|c|c|c|c|c|c|c|}
\hline \multirow[b]{2}{*}{ Depth } & \multirow[b]{2}{*}{ Sample Site } & \multicolumn{4}{|c|}{ Inorganic N (lb/ac) } & \multicolumn{4}{|c|}{ Inorganic $\mathrm{P}(\mathrm{lb} / \mathrm{ac})$} \\
\hline & & Apr 2013 & Oct 2013 & Apr 2014 & Oct 2014 & Apr 2013 & Oct 2013 & Apr 2014 & Oct 2014 \\
\hline \multirow[t]{14}{*}{$0-6 "$} & 1 & 14.5 & 76.5 & 7.0 & 10.8 & 18.7 & 22.7 & 14.5 & 7.8 \\
\hline & 2 & 3.3 & 22.9 & 1.3 & 4.6 & 13.4 & 14.7 & 4.4 & 23.0 \\
\hline & 3 & 2.7 & 25.4 & 4.2 & 3.1 & 9.2 & 6.2 & 2.9 & 1.6 \\
\hline & 4 & 8.6 & 46.9 & 2.1 & 4.3 & 22.3 & 15.3 & 10.5 & 13.3 \\
\hline & 5 & 9.8 & 173.8 & 2.7 & 3.7 & 8.2 & 33.1 & 7.1 & 2.6 \\
\hline & 6 & 3.2 & 18.7 & 2.4 & 5.9 & 11.4 & 27.4 & 3.4 & 10.5 \\
\hline & 7 & 11.6 & 36.2 & 3.4 & 4.7 & 14.7 & 10.7 & 3.8 & 4.1 \\
\hline & 8 & 4.0 & 40.0 & 6.5 & 3.5 & 8.4 & 35.6 & 13.0 & 14.0 \\
\hline & 9 & 7.2 & 33.1 & 3.4 & 3.8 & 5.1 & 30.8 & 2.8 & 2.7 \\
\hline & 10 & 7.2 & 27.2 & 4.4 & 4.0 & 11.4 & 8.6 & 5.7 & 6.3 \\
\hline & Mean & 7.2 & 50.1 & 3.7 & 4.8 & 12.3 & 20.5 & 6.8 & 8.6 \\
\hline & Max & 14.5 & 173.8 & 7.0 & 10.8 & 22.3 & 35.6 & 14.5 & 23.0 \\
\hline & Min & 2.7 & 18.7 & 1.3 & 3.1 & 5.1 & 6.2 & 2.8 & 1.6 \\
\hline & Overall Change ${ }^{[a]}$ & & & & $-33 \%$ & & & & $-30 \%$ \\
\hline
\end{tabular}


Table 7 Continued.

\begin{tabular}{|c|c|c|c|c|c|c|c|c|c|}
\hline \multirow[b]{2}{*}{ Depth } & \multirow[b]{2}{*}{ Sample Site } & \multicolumn{4}{|c|}{ Inorganic N (lb/ac) } & \multicolumn{4}{|c|}{ Inorganic $\mathrm{P}(\mathrm{lb} / \mathrm{ac})$} \\
\hline & & Apr 2013 & Oct 2013 & Apr 2014 & Oct 2014 & Apr 2013 & Oct 2013 & Apr 2014 & Oct 2014 \\
\hline \multirow[t]{14}{*}{ 6-12" } & 1 & 7.6 & 29.9 & 9.5 & 6.0 & 14.6 & 11.3 & 2.3 & 4.2 \\
\hline & 2 & 2.4 & 17.6 & 13.0 & 2.6 & 0.7 & 8.8 & 2.7 & 4.6 \\
\hline & 3 & 1.9 & 14.6 & 14.7 & 2.4 & 4.0 & 7.4 & 1.2 & 0.8 \\
\hline & 4 & 8.4 & 21.6 & 13.1 & 3.1 & 12.4 & 9.4 & 4.1 & 4.0 \\
\hline & 5 & 5.4 & 19.6 & 18.0 & 2.5 & 5.2 & 5.6 & 3.1 & 1.0 \\
\hline & 6 & 2.9 & 11.8 & 8.3 & 4.6 & 4.1 & 6.0 & 3.0 & 5.1 \\
\hline & 7 & 2.6 & 40.4 & 8.1 & 2.7 & 1.8 & 34.9 & 2.6 & 1.2 \\
\hline & 8 & 3.6 & 18.3 & 17.2 & 3.2 & 8.2 & 9.7 & 4.2 & 3.3 \\
\hline & 9 & 3.6 & 34.6 & 14.3 & 4.9 & 1.4 & 10.8 & 2.0 & 3.5 \\
\hline & 10 & 2.6 & 30.9 & 23.4 & 2.5 & 0.3 & 5.4 & 2.4 & 1.6 \\
\hline & Mean & 4.1 & 23.9 & 14.0 & 3.5 & 5.3 & 10.9 & 2.8 & 2.9 \\
\hline & Max & 8.4 & 40.4 & 23.4 & 6.0 & 14.6 & 34.9 & 4.2 & 5.1 \\
\hline & Min & 1.9 & 11.8 & 8.1 & 2.4 & 0.3 & 5.4 & 1.2 & 0.8 \\
\hline & Overall Change $^{[\mathrm{a}]}$ & & & & $-16 \%$ & & & & $-44 \%$ \\
\hline
\end{tabular}

${ }^{[a]}$ Overall change reflects the percent difference between Apr 2013 and Oct 2014 sample sets based on the mean. 
Table 8. Robertson County soil data

\begin{tabular}{cccccccccc} 
& & \multicolumn{4}{c}{ Inorganic N (lbs/ac) } & \multicolumn{5}{c}{ Inorganic P (lbs/ac) } \\
Depth & Sample Site & Apr 2013 & Oct 2013 & Apr 2014 & Oct 2014 & Apr 2013 & Oct 2013 & Apr 2014 & Oct 2014 \\
\hline $0-6 "$ & 1 & 11.6 & 23.6 & 4.8 & 3.5 & 28.0 & 3.9 & 3.9 & 2.8 \\
& 2 & 4.4 & 77.6 & 8.4 & 4.4 & 18.3 & 13.5 & 4.1 & 4.7 \\
& 3 & 15.1 & 56.7 & 4.2 & 10.0 & 19.4 & 7.2 & 1.7 & 2.9 \\
& 4 & 4.8 & 52.9 & 13.2 & 5.1 & 21.2 & 16.1 & 3.5 & 2.6 \\
& 5 & 10.2 & 55.9 & 10.7 & 5.1 & 18.1 & 13.5 & 1.8 & 3.1 \\
6 & 14.4 & 29.9 & 9.7 & 4.0 & 17.7 & 9.6 & 1.5 & 3.2 \\
& 7 & 15.8 & 52.1 & 12.0 & 4.2 & 18.2 & 6.3 & 1.7 & 2.7 \\
& 8 & 6.3 & 54.3 & 11.3 & 4.0 & 16.4 & 23.7 & 1.5 & 2.9 \\
& 9 & 5.6 & 19.6 & 6.0 & 3.0 & 16.8 & 3.6 & 1.8 & 2.3 \\
& 10 & 8.1 & 15.4 & 4.9 & 3.0 & 17.4 & 9.8 & 4.1 & 1.7 \\
\hline & Mean & 9.6 & 43.8 & 8.5 & 4.6 & 19.1 & 10.7 & 2.6 & 2.9 \\
& Max & 15.8 & 77.6 & 13.2 & 10.0 & 28.0 & 23.7 & 4.1 & 4.7 \\
& Min & 4.4 & 15.4 & 4.2 & 3.0 & 16.4 & 3.6 & 1.5 & 1.7 \\
& Overall Change ${ }^{[a]}$ & & & & $-52 \%$ & & & $-85 \%$
\end{tabular}


Table 8 Continued.

\begin{tabular}{|c|c|c|c|c|c|c|c|c|c|}
\hline \multirow[b]{2}{*}{ Depth } & \multirow[b]{2}{*}{ Sample Site } & \multicolumn{4}{|c|}{ Inorganic N (lbs/ac) } & \multicolumn{4}{|c|}{ Inorganic P (lbs/ac) } \\
\hline & & Apr 2013 & Oct 2013 & Apr 2014 & Oct 2014 & Apr 2013 & Oct 2013 & Apr 2014 & Oct 2014 \\
\hline \multirow[t]{14}{*}{$6-12 "$} & 1 & 7.6 & 18.6 & 3.6 & 1.0 & 22.9 & 2.6 & 2.1 & 0.8 \\
\hline & 2 & 3.2 & 17.9 & 4.0 & 1.0 & 18.4 & 2.5 & 1.2 & 1.2 \\
\hline & 3 & 7.7 & 12.1 & 3.2 & 1.7 & 18.8 & 2.2 & 2.0 & 0.8 \\
\hline & 4 & 2.7 & 21.4 & 3.2 & 2.1 & 20.1 & 4.2 & 1.2 & 1.1 \\
\hline & 5 & 3.0 & 18.3 & 5.9 & 1.5 & 17.5 & 4.3 & 1.2 & 0.8 \\
\hline & 6 & 15.3 & 16.5 & 2.9 & 1.2 & 17.9 & 2.7 & 1.0 & 0.9 \\
\hline & 7 & 5.6 & 19.8 & 2.5 & 1.2 & 17.7 & 43.2 & 1.0 & 0.7 \\
\hline & 8 & 5.3 & 17.6 & 7.7 & 0.8 & 16.6 & 2.3 & 1.2 & 0.7 \\
\hline & 9 & 5.1 & 15.2 & 2.2 & 1.1 & 16.8 & 3.1 & 1.2 & 0.7 \\
\hline & 10 & 6.2 & 15.1 & 2.9 & 1.7 & 17.2 & 24.6 & 1.1 & 2.0 \\
\hline & Mean & 6.2 & 17.3 & 3.8 & 1.3 & 18.4 & 9.2 & 1.3 & 1.0 \\
\hline & Max & 15.3 & 21.4 & 7.7 & 2.1 & 22.9 & 43.2 & 2.1 & 2.0 \\
\hline & Min & 2.7 & 12.1 & 2.2 & 0.8 & 16.6 & 2.2 & 1.0 & 0.7 \\
\hline & Overall Change $^{[\mathrm{a}]}$ & & & & $-78 \%$ & & & & $-95 \%$ \\
\hline
\end{tabular}

${ }^{[a]}$ Overall change reflects the percent difference between Apr 2013 and Oct 2014 sample sets based on the mean. 

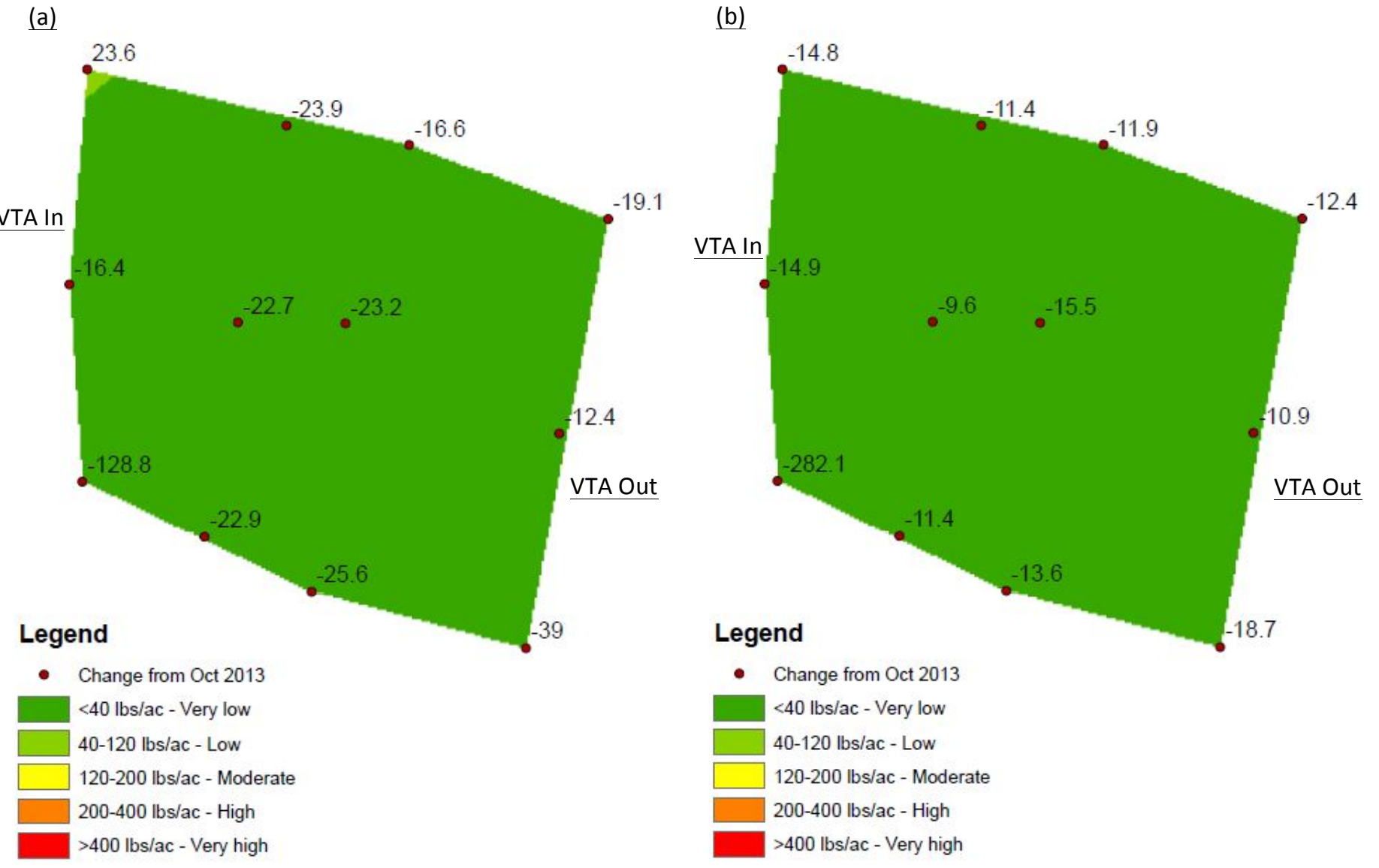

Figure 15. Inorganic $\mathrm{N}$ in Bell County soil samples (a) $0-15.24 \mathrm{~cm}$ depth, and (b) $15.24-30.48 \mathrm{~cm}$ depth 

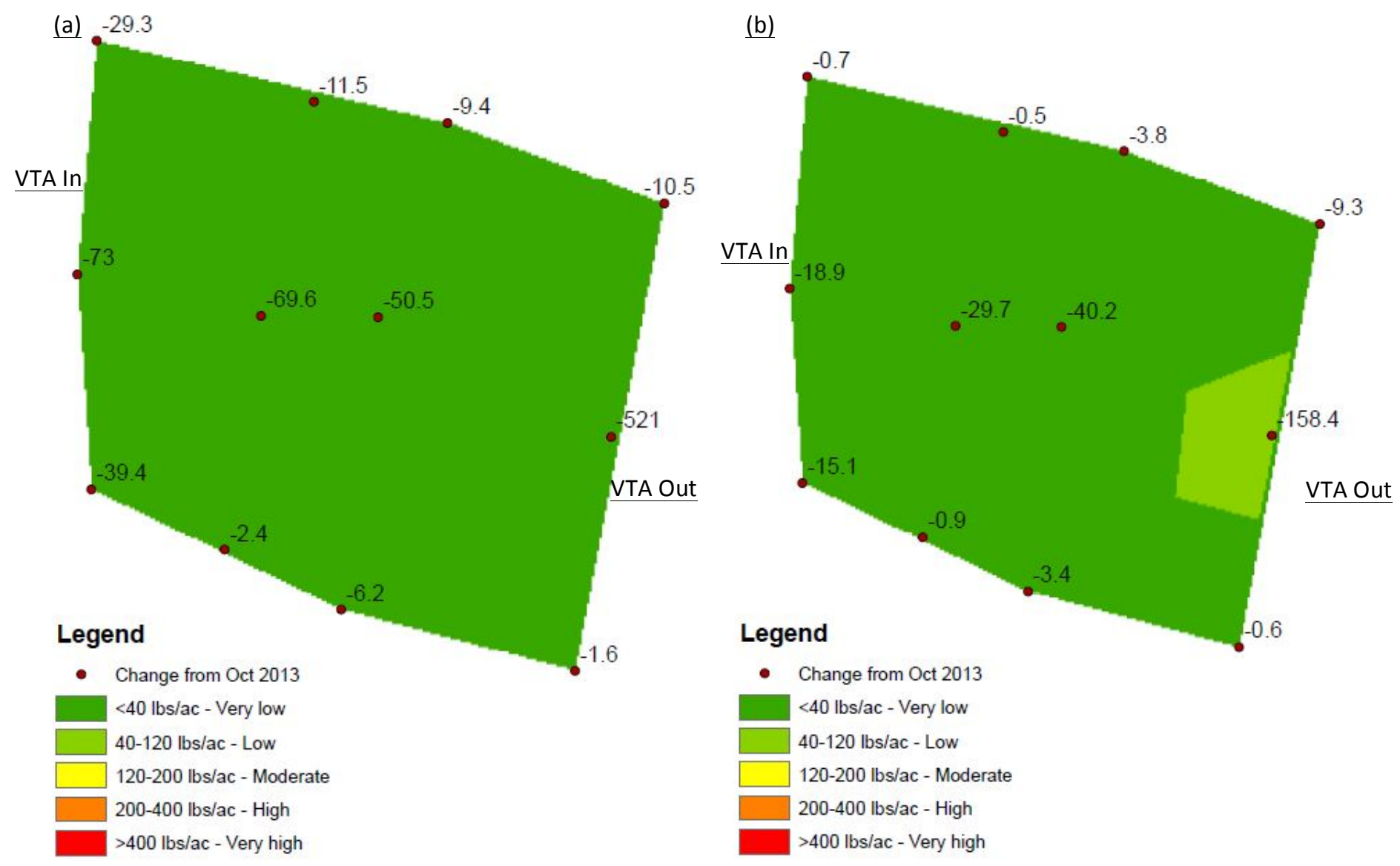

Figure 16. Inorganic P in Bell County soil samples (a) $0-15.24 \mathrm{~cm}$ depth, and (b) $15.24-30.48 \mathrm{~cm}$ depth 
(a)

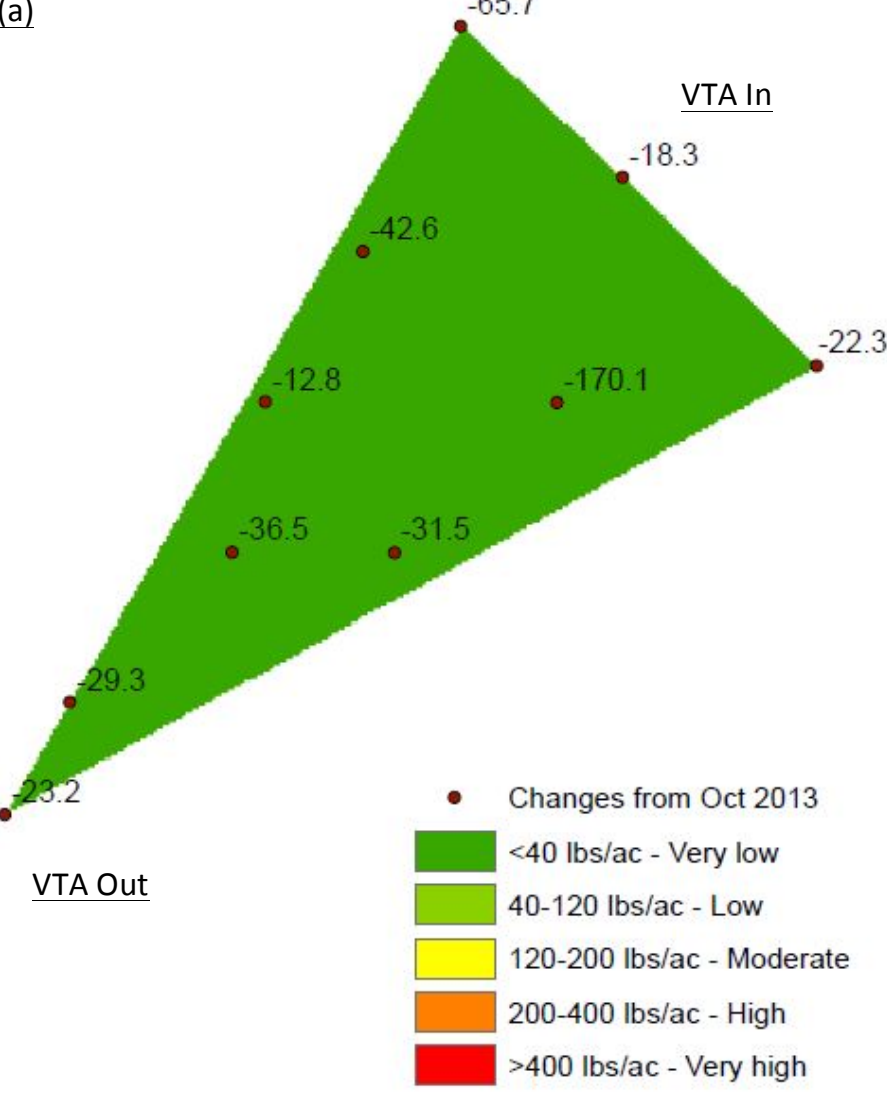

(b)

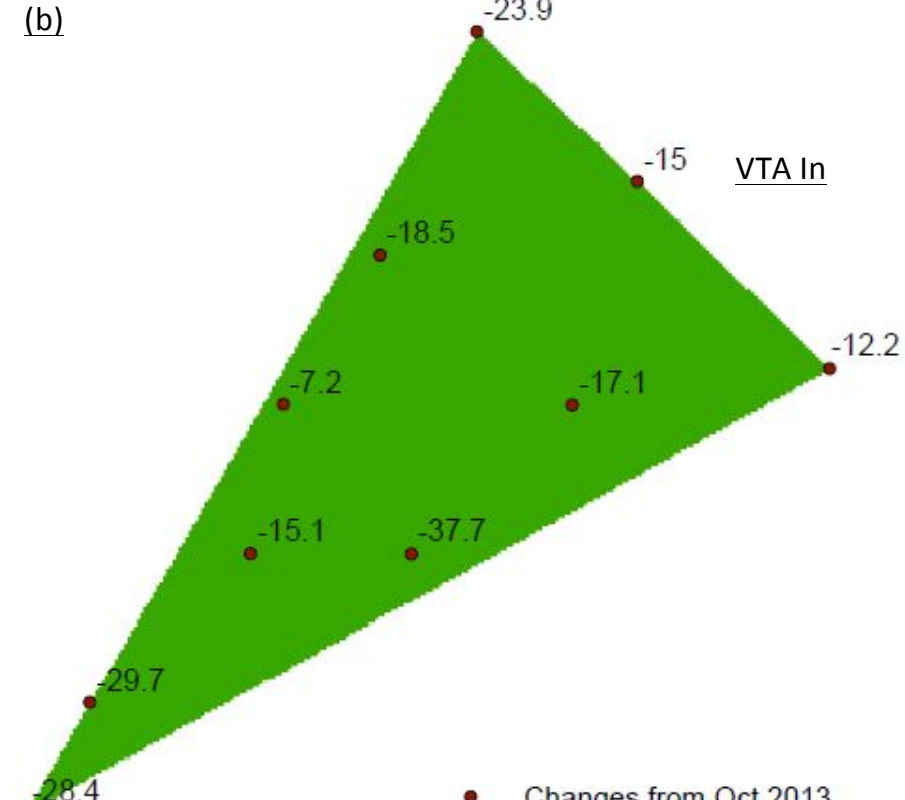

VTA Out
- $\quad$ Changes from Oct 2013 $<40 \mathrm{lbs} / \mathrm{ac}$ - Very low 40-120 lbs/ac - Low 120-200 lbs/ac - Moderate 200-400 lbs/ac - High $>400 \mathrm{lbs} / \mathrm{ac}$ - Very high

Figure 17. Inorganic $\mathrm{N}$ in Brazos County soil samples (a) $0-15.24 \mathrm{~cm}$ depth, and (b) $15.24-30.48 \mathrm{~cm}$ depth 

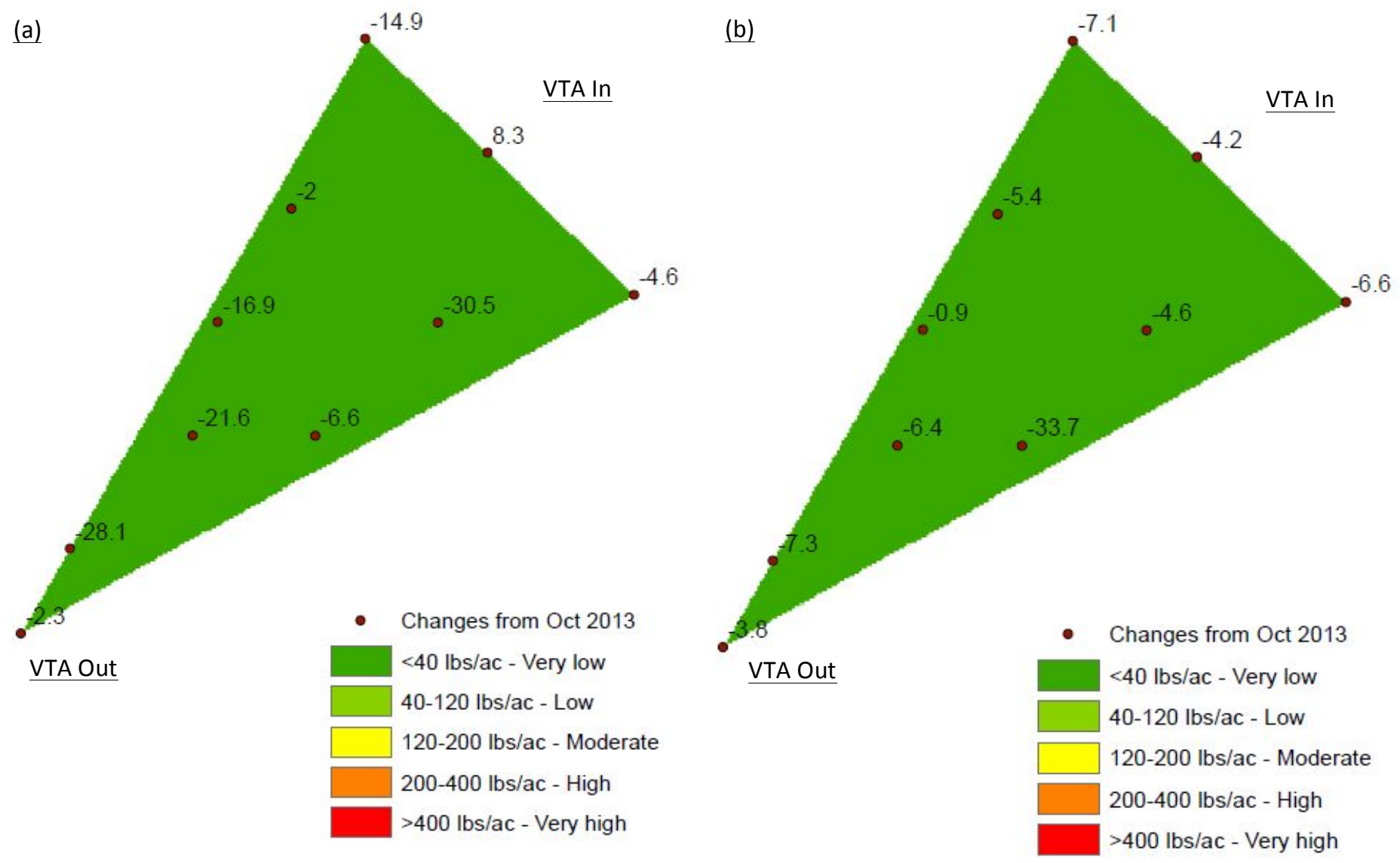

Figure 18. Inorganic P in Brazos County soil samples (a) $0-15.24 \mathrm{~cm}$ depth, and (b) $15.24-30.48 \mathrm{~cm}$ depth 

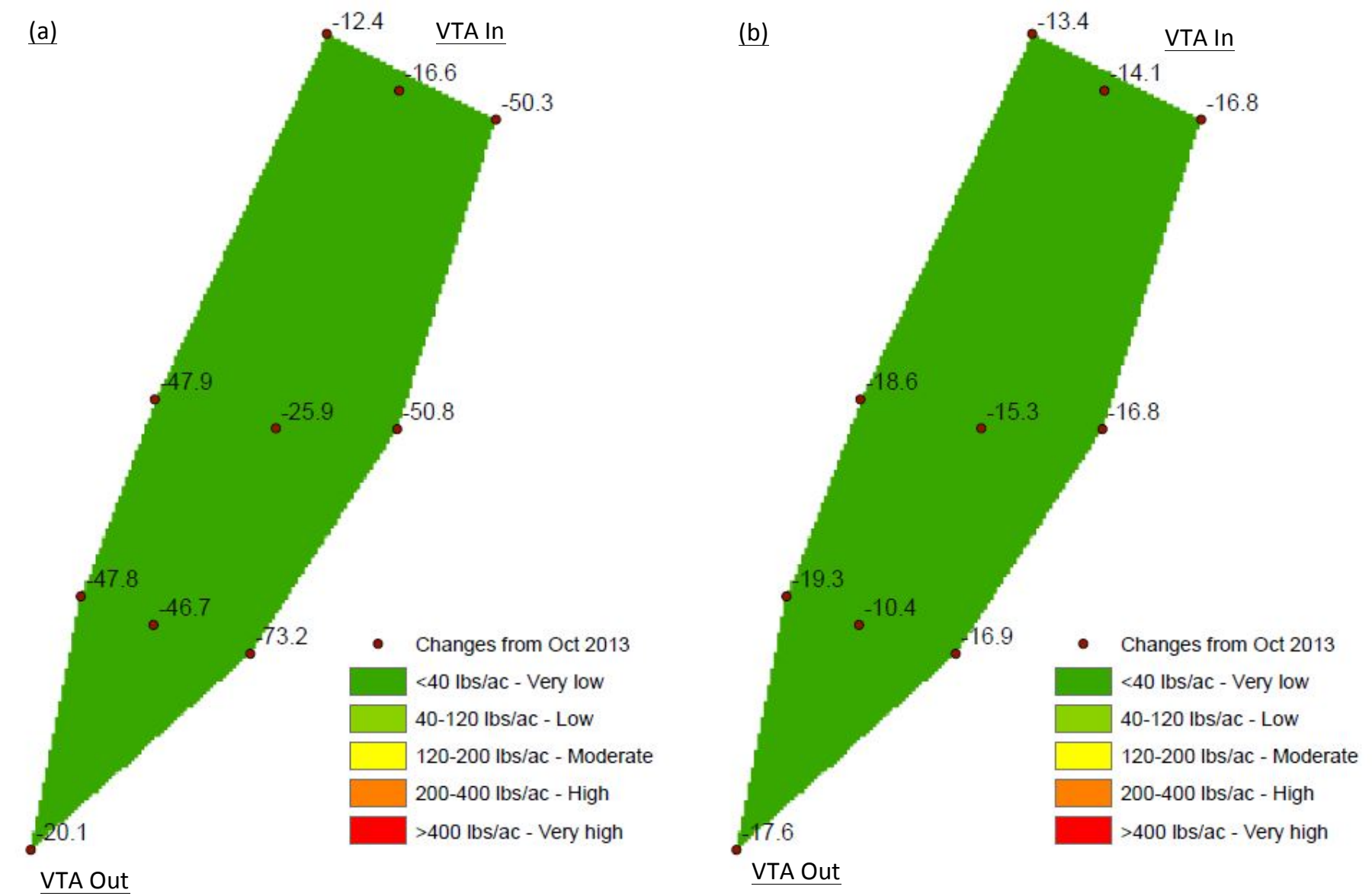

Figure 19. Inorganic $\mathrm{N}$ in Robertson County soil samples (a) $0-15.24 \mathrm{~cm}$ depth, and (b) $15.24-30.48 \mathrm{~cm}$ depth 

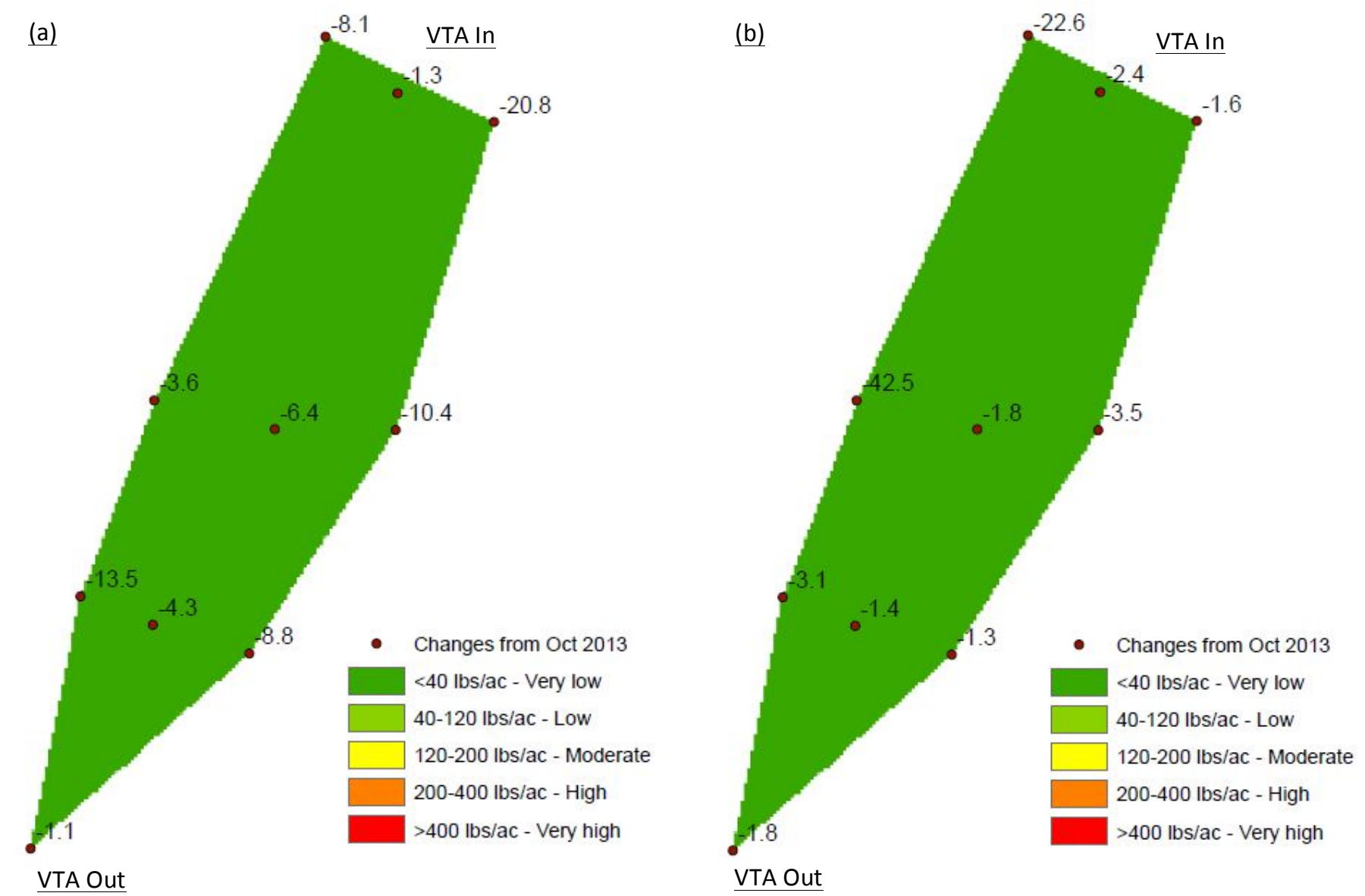

Figure 20. Inorganic P in Robertson County soil samples (a) $0-15.24 \mathrm{~cm}$ depth, and (b) $15.24-30.48 \mathrm{~cm}$ depth 


\subsubsection{Discussion}

These results imply that once the VTA was established, the initial influx of nutrients was offset by the subsequent plant uptake. This illustrates the importance of regular haying to remove nutrients from the system. Figure 3 shows the plots of data from Oct 2013 to Oct 2014 to examine potential spatial trends in soil $\mathrm{N}$ and $\mathrm{P}$ accumulation, (data from April 2013 were not used because of an error relating sampling location to lab results). The increase of $\mathrm{N}$ in Bell County VTA was found at a sampling location near the outlet of the farrowing crate drainage pipe. There was a high input of solids in this area, which was likely the cause of the increase.

There is typically more concern about the accumulation of $\mathrm{P}$ on land receiving manure because it tends to adsorb to soil particles while inorganic $\mathrm{N}$ is highly mobile and easily lost in surface runoff and percolate (Sharpley and Withers., 1994; Heathwaite et al., 1996). There was some evidence of $\mathrm{P}$ accumulation at the top of the Bell County VTA where a large amount of solids were introduced but the final set of data shows an ultimate decrease. The same area of high solids input also showed elevated $\mathrm{N}$ levels on one end of the distribution pipe. Additional data might be expected to show increased $\mathrm{N}$ and $\mathrm{P}$ concentrations in the $15.24-30.48 \mathrm{~cm}$ depth samples due to vertical movement, but these increase have not yet been seen. Continued monitoring will be important to ensure the VTA soils are not overloaded and become a source of potential groundwater contamination instead of a sink for nutrients in overland runoff (Hawkins et al., 1998). 


\section{SUMMARY AND CONCLUSIONS}

The purpose of this study was to evaluate the potential of minimally designed VTAs to reduce nutrient levels in runoff from swine facilities with small animal populations. By increasing the treatment to contribution area ratios, the VTAs were able to overcome the lack of solids pretreatment which has previously been listed as one of the most important aspects of VTA design for facilities with much larger waste streams. Mean TN concentrations were reduced by $38 \%$ - $69 \%$, and total loads were reduced by $58 \%-87 \%$ at all three sites (Table 9). There was a decrease of $25 \%-84 \%$ in TP concentrations and 50\% - 62\% in total TP load (Table 9). The impact of runoff reduction was reflected in the consistently greater decrease of nutrient loads than concentrations.

Table 9. Overall summary of water quality results

\begin{tabular}{cccccc}
\hline \multirow{2}{*}{ County } & \multicolumn{2}{c}{ TN Reduction (\%) } & \multicolumn{2}{c}{ TP Reduction (\%) } & Total Runoff \\
& Concentration $^{[a]}$ & Load $^{[a]}$ & Concentration $^{[a]}$ & Load $^{[a]}$ & Reduction (\%) \\
\hline Bell & 69 & 87 & 84 & 95 & 55 \\
Brazos & 73 & 79 & 45 & 50 & 19 \\
Robertson & 38 & 58 & 25 & 62 & 35 \\
\hline [a]
\end{tabular}

${ }^{\text {[a] }}$ Reductions are based on means for concentrations, and totals for loads. 
This marked a substantial reduction within the VTA, especially when considering loads, but VTA runoff still tended to have significantly higher nutrient levels than the control site. Bell County, the location with the solids management issue, was the only location to consistently show ideal results with most nutrient loads in VTA outflow being both significantly lower than the inflow and similar to the control site runoff. The exception was $\mathrm{NO}_{3}-\mathrm{N}$, which was typically the least decreased nutrient among all locations, similarly to past VTA research (Chaubey et al., 1994; Edwards et al., 1983). Though this research did not include any solids pretreatment, as most previous VTA studies recommend, these results still fall within the range of findings of those same studies (Koelsch et al., 2006; Chaubey et al., 1994; Barker and Young, 1984; Edwards et al., 1983). This indicates that there may be slightly different VTA design and management guidelines for these small swine facilities with less than 100 animals that would be more appropriate for their conditions.

Currently, there are approximately 560,000 hogs in production in Texas, and much like the national trend, that number has been on the decline for several years (USDA-NASS, 2014a). Less than 1\% of swine operations nationwide are similar in size to the facilities in this study (USDA-NASS, 2011). In Texas, however, over $90 \%$ of hog farms have less than 100 animals (USDA-NASS, 2014b). Therefore, this research is relevant in the quest to produce options for engaging more pork producers in the TSSWCB's WQMP program. The VTA recommendations generated from this research will fill a resource gap, but more research is still needed to develop the necessary design and management standards. 
Future inquiries into different design guidelines appropriate for very small operations would be beneficial. Analyzing the data for seasonal variations in VTA effectiveness could also prove helpful in developing management and design guidelines. A more in depth study into the correlation of VTA efficiency and site characteristics such as soil type, vegetation, area ratios, slope, and number of animals could provide important guidelines for determining which hog AFOs would be suitable for waste management via VTA. To that end, more VTA study sites (or at least several consecutive studies on various design elements at the same sites) would need to be established in order to create a large enough data set for appropriate statistical analysis. The development of other methods to create reasonable edge-of-field standards that are protective of water quality is also important. This may require the use of modelling software to relate edge-of-field and surface water pollutant levels based on VTA and watershed characteristics. By expanding the field of knowledge of their behavior on small hog farms and forming clear goals for their performance, the standalone VTA may be soundly established as an economical and practical waste management option for small swine operations across the state of Texas. 


\section{REFERENCES}

Barker, J.C., and B.A. Young. 1984. Evaluation of a vegetative filter for dairy wastewater treatment in southern Appalachia. North Carolina State University research report. Washington, D.C.: United States Department of Commerce, National Technical Information Service.

Bicudo, J.R. and S.M. Goyal. 2003. Pathogens and manure management systems: A review. Environ. Tech. 24:115-130.

Bonicamp, J.M., K.L. Martin, G.R. McBride, and R.W. Clark. 1999. Beer's law is not a straight line: Amplification of errors by transformation. Chem. Educator 4:81-88.

Burkholder, J., B. Libra, P. Weyer, S. Heathoote, D. Kolpin, P. S. Thorne, and M. Wichman. 2007. Impacts of waste from concentrated animal feeding operations on water quality. Environ. Health Perspectives 115(2): 308-312.

Campagnolo, E.R., K.R. Johnson, A. Karpati, C.S. Rubin, D.W. Koplin, M.T. Meyer, J.E. Esteban, R.W. Currier, K. Smith, K.M. Thu, and M. McGeehin. 2002. Antimicrobial residues in animal waste and water resources proximal to large-scale swine and poultry feeding operations. Sci. Total Environ. 299:89-95.

Carpenter, S.R. N.F. Caraco, D.L. Correll, R.W. Howarth, A.N. Sharpley, and V.H. Smith. 1998. Nonpoint pollution of surface waters with phosphorus and nitrogen. Ecol. Applic. 8:559-568.

Centner, T.J., M.E. Wetzstein, and J.D. Mullen. 2008. Small livestock producers with diffuse water pollutants: adopting a disincentive for unacceptable manure application practices. Desalination 226(2008): 66-71.

Chaubey, I., D.R. Edwards, T.C. Daniel, P.A. Moore, and D.J. Nichols. 1994. Effectiveness of vegetative filter strips in retaining surface applied swine manure constituents. Trans. ASABE 37(3): 845-850.

Cronk, J.K. 1996. Constructed wetlands to treat wastewater from dairy and swine operations: a review. Agric. Ecosystems Environ. 58:97-114.

Dickey, E.C., and D.H. Vanderholm. 1981. Vegetative filter treatment of livestock feedlot runoff. J. Environ. Qual. 10(3): 279-284.

Edwards, W.M., L.B. Owens, and R.K. White. 1983. Managing runoff from a small, paved, beef feedlot. J. Environ. Qual. 12(2): 281-286. 
Espinoza, L., R. Norman, N. Slaton, and M. Daniels. 2005. The nitrogen and phosphorus cycle in soils. Little Rock, Ark.: University of Arkansas Division of Agriculture: Cooperative Extension Service.

Evans, R.O., P.W. Westerman, and M.R. Overcash. 1984 Subsurface drainage water quality from land application of swine lagoon effluent. Trans. ASAE 27:473-480.

Gersberg, R.M., R.A. Gearhart, and M. Ives. 1989. Pathogen removal in constructed wetlands. In Constructed Wetlands for Wastewater Treatment, 431-445. D.A. Hammer, ed. Chelsea, Mich.: Lewis Publishers

Haney, R.L., E.B. Haney, L.R. Hossner, and J.G. Arnold. 2006. Development of a new soil extractant for simultaneous phosphorus, ammonium, and nitrate analysis. Comm. Soil Sci. Plant Analysis 37: 1511-1523.

Haney, R.L., W.F. Brinton, and E.Evans. 2008. Soil $\mathrm{CO}_{2}$ respiration: Comparison of chemical titration, $\mathrm{CO}_{2}$ IRGA analysis and the Solvita gel system. Renewable Agric.Food Syst. 23(2): 171-176.

Haney, R.L., and E.B. Haney. 2010. Simple and rapid laboratory method for rewetting dry soil for incubations. Comm. Soil Sci. Plant Analysis 41(12): 1493-1501.

Harmel, R.D., R.J. Cooper, R.M. Slade, R.L. Haney, and J.G. Arnold. 2006a. Cumulative uncertainty in measured streamflow and water quality data for small watersheds. Trans. ASABE 49(3): 689-701.

Harmel, R.D., K.W. King, B.E. Haggard, D.G. Wren and J.M. Sheridan. 2006 b. Practical guidance for discharge and water quality data collection on small watersheds. Trans. ASABE 49: 937-948.

Harmel, R.D., D.R. Smith, R.L. Haney, and M. Dozier. 2009. Nitrogen and phosphorus runoff from cropland and pasture fields fertilized with poultry litter. J. Soil Water Cons. 64(6):400-412.

Hassinger, W.L., K.A. Monahan, T.L. Scanlon, and T.D. Parsons. 2000. Nutrient management practices among swine operations of various sizes. J. American Vet. Med. Assoc. 217(10):1526-1530.

Hawkins, G.L., D.T. Hill, E.W. Rochester, and C.W. Wood. 1998. Evaluation of vegetative filter strips for swine lagoon wastewater. Trans. ASABE 41(3): 639-643.

Heathwaite, A.L., P.J. Johnes, and N.E. Peters. 1996. Trends in nutrients. Hydrological Processes 10: 263-293. 
Helsel, D.R. and R.M. Hirsch. 2002. Chapter A3: Statistical methods in water resources. In Techniques of Water-Resources Investigations of the United States Geological Survey: Book 4, Hydrologic Analysis and Interpretation. Washington, D.C.: United States Geological Survey.

Hooda, P.S., A.C. Edwards, H.A. Anderson, and A. Miller. 2000. A review of water quality in livestock farming areas. Sci. Total Environ. 250: 143-167.

Hou, X. and B.T. Jones. 2000. Inductively coupled plasma/optical emission spectrometry. In Encyclopedia of Analytical Chemistry, 9468-9485. R.A. Meyers, ed. Hoboken, N.J.: John Wiley and Sons, Ltd.

Karp, N. A. 2014. R commander an introduction. Vienna, Austria: Institute for Statistics and Mathematics, Comprehensive R Archive Network. Available at: cran.rproject.org. Accessed 29 August 2014

Khaleel, R., K.R. Reddy, and M.R. Overcash. 1980. Transport of potential pollutants in runoff water from land areas receiving animal wastes: A review. Water Res. 14: 421436.

Knight, R.L., V.W.E. Payne, Jr., R.E. Borer, R.A. Clarke, Jr., and J.H. Pries. 2000. Constructed wetlands for livestock wastewater management. Ecol. Eng. 15: 41-55.

Knowles, M.B. 2010. The latest advances in axially viewed simultaneous ICP-OES for elemental analysis. Santa Clara, Calif.: Agilent Technologies.

Koelsch, R.K., J.C. Lorimor, and K.R. Mankin. 2006. Vegetative treatment systems for management of open lot runoff: review of literature. Appl. Eng. in Agric. 22(1): 141153.

Komor, S.C., and D.S. Hansen. 2003. Attenuation of runoff and chemical loads in grass filter strips at two cattle feedlots, Minnesota, 1995-98. Report 03-4036. Denver, Colo.: U. S. Geological Survey. Water-Resources Investigations.

Kostraba, J.N., E.C. Gay, M. Rewers, and R.F. Hamman. 1992. Nitrate levels in community drinking waters and risk of IDDM: an ecological analysis. Diabetes Care 15: 1505-1508.

Lee, L.S., N. Carmosini, S.A. Sassman, H.M. Dion, and M.S. Sepúlveda. 2007. Agricultural contributions of antimicrobials and hormones on soil and water quality. Advances in Agron. 93:1-68.

Mallin, M.A. 2000. Impacts of industrial-scale swine and poultry production on rivers and estuaries. American Sci. 88:26-37. 
Mueller, D.H., R.C. Wendt, and T.C. Daniel. 1984. Phosphorus losses as affected by tillage and manure application. Soil Sci. Soc. America J. 48:901-905.

Neumann, A., G. Torstensson, H. Aronsson. 2012. Nitrogen and phosphorus leaching losses from potatoes with different harvest times and following crops. Field Crops Res. 133: 130-138.

Richardson, C.J. 1985. Mechanisms controlling phosphorus retention capacity in freshwater wetlands. Science 228:1424-1427.

SEAL Analytical. 2009. Method No. G-103-93 Rev. 10: Posphate in water, waste water and soil extracts and other aqueous samples. Mequon, Wisc: SEAL Analytical, Inc.

SEAL Analytical. 2010. Method No. G-200-97 Rev. 6: Nitrate and nitrite in water and waste water and other aqueous extracts. Mequon, Wisc: SEAL Analytical, Inc.

SEAL Analytical. 2011. AutoAnalyzer 3 High resolution operation manual. Publication No. MB7-31EN-03. Mequon, Wisc: SEAL Analytical, Inc.

SEAL Analytical. 2012a. AA3 Customer support manual. Mequon, Wisc: SEAL Analytical, Inc.

SEAL Analytical. 2012b. Method No. G-102-93 Rev. 8: Ammonia in water, waste water, and soil extracts and other aqueous samples. Mequon, Wisc: SEAL Analytical, Inc.

Sharpley, A.N. and P.J.A. Withers. 1994. The environmentally sound management of agricultural phosphorus. Fertilizer Research 39:133-146.

Sharpley, A., P. Kleinman, J. Weld. 2004. Assessment of best management practices to minimize the runoff of manure-bourne phosphorus in the United States. New Zealand J. Agric. Res. 47:461-477.

Sherer, B.M., J.R. Miner, J.A. Moore and J.C. Buckhouse. 1992 Indicator bacteria survival in stream sediments. J. Environ. Quality 21:591-59.

TCEQ. 2012. Texas nonpoint source management program. Austin, Texas: Texas Commission on Environmental Quality.

Teledyne Instruments. 2003. Apollo with Total Nitrogen User Manual. Part No. 14900N-074 Rev. B. Mason, Ohio: Teledyne Tekmar.

Teledyne Isco. 2011. Chapter 4: Flumes. In Isco Open Channel Flow Measurement Handbook, 53-105. D. K. Walkowiak, ed. Lincoln, Neb,: Teledyne Isco, Inc. 
Teledyne Isco. 2013a. 730 Bubbler flow module. Lincoln, Neb.: Teledyne Technologies Incorporated. Available at: http://www.isco.com/products/products3.asp?PL=2016040. Accessed 10 Oct 2014

Teledyne Isco. 2013b. 750 Area velocity flow module. Lincoln, Neb.: Teledyne Technologies Incorporated. Available at: http://www.isco.com/products/products3.asp?PL=2016050. Accessed 10 Oct 2014

Teledyne Isco. 2013c. 6712 Portable samplers: Installation and operation guide. Lincoln, Neb.: Teledyne Technologies Incorporated.

TSSWCB. 2004. Water quality management plan program: Managing and abating agricultural and silvicultural nonpoint source pollution. Temple, Texas: Texas State Soil and Water Conservation Board.

TSSWCB. 2005. Water quality management plan initiative for the nonpoint source pork industry. Temple, Texas: Texas State Soil and Water Conservation Board.

USDA and USEPA. 1999. Unified national strategy for animal feeding operations: March 9, 1999. Washington, D.C.: United States Department of Agriculture and United States Environmental Protection Agency.

USDA-NASS. 2011. Farms, land in farms, and livestock operations 2010 summary. Washington, D.C.: United States Department of Agriculture National Agricultural Statistics Service.

USDA-NASS. 2014a. Quarterly hog and pig report. Agriculture Counts: PR-116-14. Austin, Tex: Southern Plains Regional Office, United States Department of Agriculture National Agricultural Statistics Service.

USDA-NASS. 2014b. 2012 Census of agriculture, Volume 1, Chapter 2 - US State Level. Washington, D.C.: United States Department of Agriculture National Agricultural Statistics Service.

USDA-NRCS. 1997a. Official Soil Series Descriptions -Houston Black Series. Lincoln, Neb: United States Department of Agriculture, Natural Resources Conservation Service. Available at: https://soilseries.sc.egov.usda.gov/OSD_Docs/H/HOUSTON_BLACK.html. Accessed 3 March 2014.

USDA-NRCS. 1997b. Official Soil Series Descriptions -Zack Series. Lincoln, Neb: United States Department of Agriculture, Natural Resources Conservation Service. 
Available at: https://soilseries.sc.egov.usda.gov/OSD_Docs/Z/ZACK.html. Accessed: 3 March 2014.

USDA-NRCS. 2002a. Official Soil Series Descriptions -Booneville Series. Lincoln, Neb: United States Department of Agriculture, Natural Resources Conservation Service. Available at: https://soilseries.sc.egov.usda.gov/OSD Docs/B/BOONVILLE.html. Accessed: 3 March 2014

USDA-NRCS. 2002b. Official Soil Series Descriptions -Tabor Series. Lincoln, Neb: United States Department of Agriculture, Natural Resources Conservation Service. Available at: https://soilseries.sc.egov.usda.gov/OSD_Docs/T/TABOR.html. Accessed: 3 March 2014.

USDA-NRCS. 2006. Vegetative treatment systems for open lot runoff: A collaborative report. Washington, D.C.: United States Department of Agriculture - Natural Resources Conservation Service.

USDA-SCS. 1984. SCS engineering field handbook, Chapter 2. Washington, D.C.: United States Department of Agriculture - Soil Conservation Service.

USEPA. 2002. 2000 National water quality inventory. EPA-841-R-02-001. Washington, D.C.: United States Environmental Protection Agency, Office of Water.

USEPA. 2003. National pollutant discharge elimination system permit regulation and efficient limitation guidelines and standards for concentrated animal feeding operations (CAFOs): Final rule. Federal Register 68(29): 7176-7274.

USEPA. 2013. Literature review of livestock and poultry manure. EPA-820-R-13-002. Washington, D.C.: United States Environmental Protection Agency, Office of Water.

Varian Instruments. 2001. Vista PRO and MPX ICP-OES Spectrometers Operation Manual. Publication No. 8510165900. Walnut Creek, Cal.: Varian Instruments.

Ward M.H., T.M. deKok, P. Levallois, J. Brender, G. Gulis, B.T. Nolan et al. 2005. Workgroup report: drinking-water nitrate and health - recent findings and research needs. Environ. Health Perspective 113:1607-1614.

Westerman P.W., R.L. Huffman, and J.S. Feng. 1995. Swine-lagoon seepage in sandy soil. Trans. ASAE 38(6)1749-1760.

Woodbury, B.L., J.A. Nienaber, and R.A. Eigenberg. 2005. Effectiveness of a passive feedlot runoff control system using a vegetative treatment area for nitrogen control. Appl. Eng. Agric. 21(4): 581-588. 


\section{APPENDIX}

Table A-1. Actual flow intervals for sampler programs

\begin{tabular}{ccccc}
\hline County & Site & $\begin{array}{c}\text { actual flow interval } \\
(\mathrm{mm})\end{array}$ & $\begin{array}{c}\text { area } \\
(\mathrm{ac})\end{array}$ & $\begin{array}{c}\text { sampling interval } \\
\left(\mathrm{ft}^{3}\right)\end{array}$ \\
\hline Bell & VTA In & 1.57 & 0.368 & 82.4 \\
& VTA Out & 1.30 & 1.477 & 275.4 \\
& Control & 1.24 & 1.175 & 207.5 \\
\hline \multirow{2}{*}{ Brazos } & VTA In & 1.54 & 0.086 & 18.9 \\
& VTA Out & 1.68 & 0.392 & 94.3 \\
& Control & 0.54 & 3.000 & 188.6 \\
\hline Robertson & VTA In & 1.38 & 0.067 & 13.2 \\
& VTA Out & 1.23 & 0.354 & 62.3 \\
& Control & 1.33 & 0.386 & 73.6 \\
\hline
\end{tabular}


Table A-2. Data for peak discharge calculations

\begin{tabular}{|c|c|c|c|c|c|c|c|c|c|}
\hline & \multicolumn{3}{|c|}{ Bell County } & \multicolumn{3}{|c|}{ Brazos County } & \multicolumn{3}{|c|}{ Robertson County } \\
\hline & VTA In & VTA Out & Control & VTA In & VTA Out & Control $^{[\mathrm{f}]}$ & VTA In & VTA Out & Control \\
\hline Rainfall Distribution Type $^{[a]}$ & III & III & III & III & III & III & III & III & III \\
\hline Drainage are $\mathrm{a}^{[\mathrm{b}]}(\mathrm{ac})$ & 0.3 & 1.2 & 0.5 & 0.1 & 0.4 & 1.0 & 0.2 & 0.5 & 0.4 \\
\hline Curve number & 86 & 78 & 78 & 86 & 78 & 81 & 86 & 78 & 76 \\
\hline Slope (\%) & 2.0 & 2.0 & 2.0 & 3.0 & 2.5 & 3.2 & 2.0 & 1.6 & 1.6 \\
\hline Flow length (ft) & 140 & 300 & 553 & 80 & 254 & 510 & 100 & 170 & 145 \\
\hline Time of Concentration ${ }^{[\mathrm{c}]}(\mathrm{h})$ & 0.07 & 0.15 & 0.25 & 0.03 & 0.12 & 0.17 & 0.05 & 0.12 & 0.14 \\
\hline Initial abstraction $^{[\mathrm{d}]}$ (in) & 0.33 & 0.56 & 0.56 & 0.33 & 0.56 & 0.46 & 0.33 & 0.56 & 0.63 \\
\hline Rainfall $^{[\mathrm{ee}]}$ (in) & 7.8 & 7.8 & 7.8 & 8.8 & 8.8 & 8.8 & 8.4 & 8.4 & 8.4 \\
\hline $\begin{array}{l}\text { Calculated peak discharge } \\
\text { (cfs) }\end{array}$ & 2.9 & 8.8 & 3 & 1.1 & 3.9 & 6.0 & 1.9 & 2.4 & 2.3 \\
\hline
\end{tabular}

${ }^{[\text {a] }}$ Rainfall distribution type was based on geographic location and determined using Figure 2-1 of the Engineering Field Handbook (USDA-SCS, 1984)

${ }^{[b]}$ Drainage areas here may be slightly different than actual areas listed in body of text. Discrepancies in area information were discovered after these calculations were done.

${ }^{[\mathrm{c}]}$ Time of concentration was calculated using equation within worksheet

[d] Initial abstraction was determined, based on curve number, from Table 2-4 of the Engineering Field Handbook (USDA-SCS, 1984)

${ }^{[e]}$ All rainfall amounts are for a 25-year, 24-hour storm

${ }^{[\mathrm{f}]}$ Brazos control site peak discharge was determined by Brazos County NRCS field office. 
Workaheet 2: Time of concentration and peak discharge

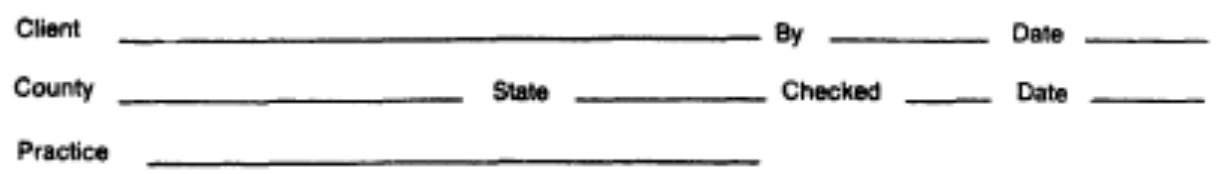

Estimabing time of concentration

1. Data:

Raintal diatribution type $. \ldots \ldots \ldots, \ldots \ldots \ldots, \ldots \ldots, \ldots, \ldots, \ldots,=$

(A. IA, II, III)

Drainage area

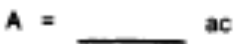

Runoff curve number

$\mathrm{CN}=$

(Worksheet 1)

Watershed slope

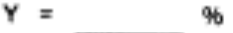

Flow length

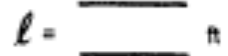

2. $T_{c}$ using $\mathcal{\ell}, \mathrm{Y}, \mathrm{CN}$ and figure $2-27$.

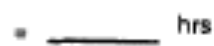

or using equation $2-5$

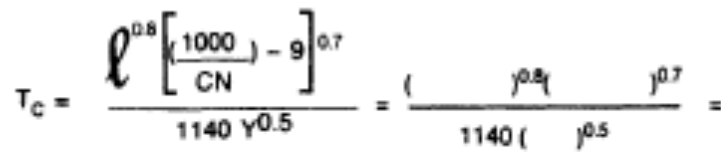
hrs

Estimating peak discharge

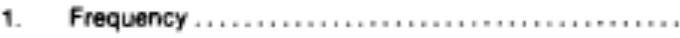

2. Raintall, $P$ (24-hour) .

in

\begin{tabular}{|l|l|l|}
\hline Storm $* 1$ & Storm $\mathbf{~ 2 ~}$ & Storm 13 \\
\hline & & \\
\hline & & \\
\hline
\end{tabular}

3.

Initial abstraction, 1 (Use CN with table 2-4)

in

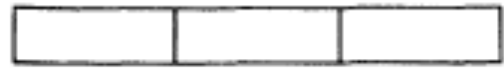

4. Compute $\mathrm{I}_{\mathrm{a}} / \mathrm{P}$ ratios.

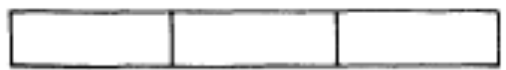

5. Unit peak discharge $Q_{\text {, }}$ (Use $T_{c}$ and $\mathrm{l}_{\mathrm{a}} / \mathrm{P}$ with exhibat 2-11)

cts/ac/in

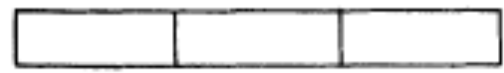

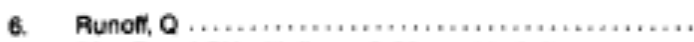
(Use $P$ and $C N$ with figure 2-26 or table 2-2)

in

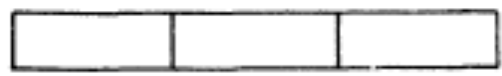

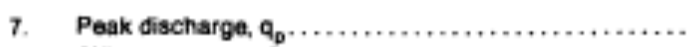
(Where $a_{p}=a_{v} A Q$ )

cts

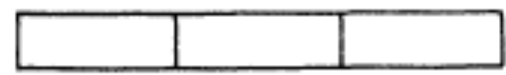

Figure A-1. Worksheet 2 from Engineering Field Handbook (USDA-SCS, 1984). 
Table A-3. Shapiro-Wilk normality test $\mathrm{p}$-values ${ }^{[\mathrm{a}]}$

\begin{tabular}{|c|c|c|c|c|c|c|c|c|c|c|c|}
\hline \multirow[b]{2}{*}{ County } & \multirow{2}{*}{ runoff } & \multicolumn{5}{|c|}{ Concentrations } & \multicolumn{5}{|c|}{ Loads } \\
\hline & & $\mathrm{NO}_{3}-\mathrm{N}$ & $\mathrm{NH}_{3}-\mathrm{N}$ & $\mathrm{PO}_{4}-\mathrm{P}$ & $\mathrm{TN}$ & $\mathrm{TP}$ & $\mathrm{NO}_{3}-\mathrm{N}$ & $\mathrm{NH}_{3}-\mathrm{N}$ & $\mathrm{PO}_{4}-\mathrm{P}$ & $\mathrm{TN}$ & $\mathrm{TP}$ \\
\hline Bell & $1.61 \mathrm{E}-09$ & $1.95 \mathrm{E}-09$ & $1.30 \mathrm{E}-06$ & $4.39 \mathrm{E}-06$ & $2.82 \mathrm{E}-04$ & $1.89 \mathrm{E}-09$ & $1.95 \mathrm{E}-10$ & $1.42 \mathrm{E}-11$ & $2.97 \mathrm{E}-10$ & 4.67E-09 & $4.71 \mathrm{E}-11$ \\
\hline Brazos & $7.05 \mathrm{E}-10$ & $2.02 \mathrm{E}-12$ & $5.29 \mathrm{E}-11$ & $1.96 \mathrm{E}-10$ & $5.73 \mathrm{E}-09$ & $1.87 \mathrm{E}-14$ & 4.79E-14 & $6.12 \mathrm{E}-11$ & $1.55 \mathrm{E}-12$ & $3.18 \mathrm{E}-10$ & $1.03 \mathrm{E}-14$ \\
\hline Robertson & $5.71 \mathrm{E}-06$ & $2.04 \mathrm{E}-05$ & $5.56 \mathrm{E}-10$ & $5.56 \mathrm{E}-06$ & $1.03 \mathrm{E}-07$ & $3.99 \mathrm{E}-06$ & $2.27 \mathrm{E}-07$ & $1.59 \mathrm{E}-07$ & $1.23 \mathrm{E}-07$ & $5.03 \mathrm{E}-05$ & $8.18 \mathrm{E}-06$ \\
\hline
\end{tabular}

Table A-4. Hypothesis test p-values

\begin{tabular}{|c|c|c|c|c|c|c|c|c|c|c|c|}
\hline \multirow[b]{3}{*}{ Bell } & \multicolumn{6}{|c|}{ Wilcoxon rank-sum test $\mathrm{p}$-value and $\mathrm{H}_{\mathrm{o}}$ result $^{[\mathrm{a}]}$} & \multicolumn{5}{|c|}{ Wilcoxon signed-rank test $\mathrm{p}$-value and $\mathrm{H}_{\mathrm{o}}$ result ${ }^{[\mathrm{a}]}$} \\
\hline & \multirow[t]{2}{*}{ runoff } & \multicolumn{5}{|c|}{ Concentrations } & \multirow[b]{2}{*}{$\mathrm{NO}_{3}-\mathrm{N}$} & \multicolumn{3}{|c|}{ Loads } & \multirow[b]{2}{*}{$\mathrm{TP}$} \\
\hline & & $\mathrm{NO}_{3}-\mathrm{N}$ & $\mathrm{NH}_{3}-\mathrm{N}$ & $\mathrm{PO}_{4}-\mathrm{P}$ & $\mathrm{TN}$ & TP & & $\mathrm{NH}_{3}-\mathrm{N}$ & $\mathrm{PO}_{4}-\mathrm{P}$ & $\mathrm{TN}$ & \\
\hline in v. out & $0.79(\mathrm{~F})$ & $0.35(\mathrm{~F})$ & $0.03(\mathrm{R})$ & $0.00(\mathrm{R})$ & $0.00(\mathrm{R})$ & $0.01(\mathrm{R})$ & $0.09(\mathrm{~F})$ & $0.18(\mathrm{~F})$ & $0.03(\mathrm{R})$ & $0.02(\mathrm{R})$ & $0.12(\mathrm{~F})$ \\
\hline out v. ctrl & $0.61(\mathrm{~F})$ & $0.05(\mathrm{~F})$ & $0.20(\mathrm{~F})$ & $0.02(\mathrm{R})$ & $0.09(\mathrm{~F})$ & $0.30(\mathrm{~F})$ & $0.87(\mathrm{~F})$ & $0.42(\mathrm{~F})$ & $1.00(\mathrm{~F})$ & $0.30(\mathrm{~F})$ & $0.91(\mathrm{~F})$ \\
\hline in v. ctrl & $0.41(\mathrm{~F})$ & $1.00(\mathrm{~F})$ & $0.00(\mathrm{R})$ & $0.00(\mathrm{R})$ & $0.00(\mathrm{R})$ & $0.00(\mathrm{R})$ & $0.23(\mathrm{~F})$ & $0.00(\mathrm{R})$ & $0.00(\mathrm{R})$ & $0.00(\mathrm{R})$ & $0.00(\mathrm{R})$ \\
\hline \multicolumn{12}{|l|}{ Brazos } \\
\hline in v. out & $0.27(\mathrm{~F})$ & $0.56(\mathrm{~F})$ & $0.00(\mathrm{R})$ & $0.00(\mathrm{R})$ & $0.00(\mathrm{R})$ & $0.00(\mathrm{R})$ & $0.47(\mathrm{~F})$ & $0.00(\mathrm{R})$ & $0.00(\mathrm{R})$ & $0.00(\mathrm{R})$ & $0.00(\mathrm{R})$ \\
\hline out v. ctrl & $0.02(\mathrm{R})$ & $0.00(\mathrm{R})$ & $0.00(\mathrm{R})$ & $0.00(\mathrm{R})$ & $0.00(\mathrm{R})$ & $0.00(\mathrm{R})$ & $0.00(\mathrm{R})$ & $0.00(\mathrm{R})$ & $0.00(\mathrm{R})$ & $0.00(\mathrm{R})$ & $0.00(\mathrm{~F})$ \\
\hline in v. ctrl & $0.00(\mathrm{R})$ & $0.24(\mathrm{~F})$ & $0.00(\mathrm{R})$ & $0.00(\mathrm{R})$ & $0.00(\mathrm{R})$ & $0.00(\mathrm{R})$ & $0.00(\mathrm{R})$ & $0.00(\mathrm{R})$ & $0.00(\mathrm{R})$ & $0.00(\mathrm{R})$ & $0.00(\mathrm{R})$ \\
\hline \multicolumn{12}{|l|}{ Robertson } \\
\hline in v. out & $0.51(\mathrm{~F})$ & $0.97(\mathrm{~F})$ & $0.45(\mathrm{~F})$ & $0.21(\mathrm{~F})$ & $0.67(\mathrm{~F})$ & $0.83(\mathrm{~F})$ & $0.02(\mathrm{R})$ & $0.06(\mathrm{~F})$ & $0.00(\mathrm{R})$ & $0.02(\mathrm{R})$ & $0.06(\mathrm{~F})$ \\
\hline out v. ctrl & $0.38(\mathrm{~F})$ & $0.51(\mathrm{~F})$ & $0.24(\mathrm{~F})$ & $0.04(\mathrm{R})$ & $0.19(\mathrm{~F})$ & $0.19(\mathrm{~F})$ & $0.06(\mathrm{~F})$ & $1.00(\mathrm{~F})$ & $0.10(\mathrm{~F})$ & $0.10(\mathrm{~F})$ & $0.06(\mathrm{~F})$ \\
\hline in v. ctrl & $0.64(\mathrm{~F})$ & $0.31(\mathrm{~F})$ & $0.42(\mathrm{~F})$ & $0.07(\mathrm{~F})$ & $0.64(\mathrm{~F})$ & $0.11(\mathrm{~F})$ & $0.02(\mathrm{R})$ & $0.06(\mathrm{~F})$ & $0.00(\mathrm{R})$ & $0.01(\mathrm{R})$ & $0.04(\mathrm{R})$ \\
\hline
\end{tabular}


Table A-5. Bell County concentration data ${ }^{[\mathrm{a}]}$

\begin{tabular}{|c|c|c|c|c|c|c|c|c|c|c|c|c|c|c|c|c|c|c|c|}
\hline \multirow{2}{*}{ Storm Date } & \multirow{2}{*}{$\begin{array}{l}\text { rainfall } \\
\text { (in) }\end{array}$} & \multicolumn{3}{|c|}{ runoff volume $(\mathrm{mm})$} & \multicolumn{3}{|c|}{ NO3-N (mg/L) } & \multicolumn{3}{|c|}{$\mathrm{NH4}-\mathrm{N}(\mathrm{mg} / \mathrm{L})$} & \multicolumn{3}{|c|}{ PO4-P (mg/L) } & \multicolumn{3}{|c|}{$\mathrm{TN}(\mathrm{mg} / \mathrm{L})$} & \multicolumn{3}{|c|}{$\mathrm{TP}(\mathrm{mg} / \mathrm{L})$} \\
\hline & & VTA In & VTA Out & Control & VTA In & VTA Out & Control & VTA In & VTA Out & Control & VTA In & VTA Out & Control & VTA In & VTA Out & Control & Bell IN & Bell OUT & Bell CONT \\
\hline |1/9/2013 & 2.98 & 34.30 & 9.50 & 27.14 & 15.65 & 5.04 & 1.38 & 0.00 & 0.00 & 0.00 & 32.00 & 5.79 & 0.78 & 15.4 & 5.5 & 1.7 & 197.0 & $\begin{array}{l}44.4 \\
\end{array}$ & 5.6 \\
\hline $2 / 10 / 2013$ & 1.64 & 6.38 & 0.00 & 13.96 & 17.95 & - & 1.96 & 0.00 & - & 0.00 & 22.06 & - & 0.81 & 15.2 & - & 2.7 & 152.0 & - & 5.7 \\
\hline 3/10/2013 & 0.10 & 0.00 & 0.00 & 1.24 & - & - & 0.75 & - & - & 0.03 & - & - & 0.48 & - & - & 1.3 & - & - & 4.9 \\
\hline $5 / 16 / 2013$ & 2.00 & 15.81 & 10.45 & 9.87 & 0.04 & 1.77 & 0.64 & 14.32 & 1.13 & 0.12 & 24.53 & 1.45 & 0.38 & 22.4 & 3.8 & 1.3 & 27.9 & 1.5 & 0.4 \\
\hline $5 / 21 / 2013$ & 1.41 & 0.00 & 6.52 & 7.37 & - & 1.84 & 0.60 & - & 0.85 & 0.44 & - & 1.43 & 0.57 & - & 3.6 & 1.8 & - & 1.5 & 0.6 \\
\hline $7 / 14 / 2013$ & 0.66 & 7.81 & 0.00 & 0.00 & 0.00 & - & - & 10.81 & - & - & 16.05 & - & - & 16.5 & - & - & 16.4 & - & - \\
\hline $10 / 13 / 2013$ & 2.06 & $\mathrm{n} / \mathrm{a}$ & $\mathrm{n} / \mathrm{a}$ & $\mathrm{n} / \mathrm{a}$ & $\mathrm{n} / \mathrm{a}$ & $\mathrm{n} / \mathrm{a}$ & $\mathrm{n} / \mathrm{a}$ & $n / a$ & $\mathrm{n} / \mathrm{a}$ & $\mathrm{n} / \mathrm{a}$ & $\mathrm{n} / \mathrm{a}$ & $\mathrm{n} / \mathrm{a}$ & $\mathrm{n} / \mathrm{a}$ & $\mathrm{n} / \mathrm{a}$ & $\mathrm{n} / \mathrm{a}$ & $\mathrm{n} / \mathrm{a}$ & $n / a$ & $\mathrm{n} / \mathrm{a}$ & $n / a$ \\
\hline $10 / 17 / 2013$ & 0.89 & 6.16 & 0.00 & 0.00 & 2.55 & - & - & 6.76 & - & - & 8.00 & - & - & 10.0 & - & - & 10.2 & - & - \\
\hline $10 / 27 / 2013$ & 1.24 & 6.29 & 0.00 & 6.21 & 0.00 & - & 0.32 & 5.88 & - & 0.30 & 16.25 & - & 0.60 & 12.8 & - & 1.3 & 18.7 & - & 0.7 \\
\hline $10 / 31 / 2013$ & 6.80 & $n / a$ & $n / a$ & $n / a$ & $n / a$ & $n / a$ & $n / a$ & $n / a$ & $\mathrm{n} / \mathrm{a}$ & $n / a$ & $\mathrm{n} / \mathrm{a}$ & $n / a$ & $n / a$ & $n / a$ & $n / a$ & $n / a$ & $n / a$ & $n / a$ & $n / a$ \\
\hline $11 / 22 / 2013$ & 0.91 & 1.57 & 0.00 & 3.77 & 0.05 & - & 0.36 & 4.71 & & 0.16 & 12.18 & - & 0.77 & 6.09 & 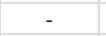 & 1.4 & 246.08 & - & 22.6 \\
\hline $4 / 6 / 2014$ & 1.60 & 20.90 & 16.07 & 13.40 & 15.01 & 5.53 & 1.77 & 0.01 & 0.02 & 0.02 & 26.20 & 3.10 & 0.70 & 17.9 & 7.0 & 2.6 & 27.8 & 4.1 & 1.6 \\
\hline $5 / 13 / 2014$ & 2.55 & 4.70 & 1.30 & 2.43 & 0.60 & 2.86 & 0.59 & 6.98 & 1.12 & 0.26 & 16.04 & 3.40 & 0.80 & 11.2 & 6.3 & 2.3 & 18.5 & 3.8 & 0.9 \\
\hline $5 / 27 / 2014$ & 1.44 & 1.57 & 0.00 & 2.49 & 0.00 & - & 0.22 & 12.27 & - & 0.56 & 13.68 & - & 0.91 & 24.0 & - & 2.7 & 15.5 & - & 0.8 \\
\hline $5 / 28 / 2014$ & 0.31 & 1.57 & 0.00 & 1.24 & 0.00 & - & 0.01 & 11.68 & - & 0.53 & 14.22 & - & 1.02 & 18.7 & - & 2.3 & 18.9 & - & 0.9 \\
\hline 6/10/2014 & 1.32 & 3.13 & 0.00 & 2.75 & 0.19 & - & 0.06 & 2.83 & - & 0.37 & 6.64 & - & 0.69 & 14.1 & - & 2.0 & 15.8 & - & 0.9 \\
\hline $7 / 18 / 2014$ & 2.44 & 12.54 & 7.80 & 4.93 & 2.48 & 0.28 & 0.12 & 4.21 & 0.15 & 0.00 & 9.14 & 1.53 & 0.61 & 10.8 & 1.6 & 1.3 & 12.0 & 1.8 & 0.6 \\
\hline $10 / 13 / 2014$ & 0.94 & 0.00 & 0.00 & 6.18 & - & - & 0.19 & - & - & 0.29 & - & - & 0.80 & - & - & 2.5 & - & - & 1.3 \\
\hline $11 / 6 / 2014$ & 1.56 & 0.00 & 0.00 & 1.24 & - & - & 0.79 & - & - & 0.01 & - & - & 8.83 & - & - & 17.0 & - & - & 12.5 \\
\hline max $=$ & "6.80 & $\begin{array}{c}34.30 \\
\end{array}$ & $\begin{array}{ll}16.07 \\
\end{array}$ & 27.14 & \begin{tabular}{l|l|}
17.95 \\
\end{tabular} & $\begin{array}{l}5.53 \\
\end{array}$ & 1.96 & \begin{tabular}{l|l}
14.32 \\
\end{tabular} & $\begin{array}{l}1.13 \\
\end{array}$ & 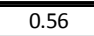 & 32.00 & $\begin{array}{l}5.79 \\
\end{array}$ & $\begin{array}{l}8.83 \\
\end{array}$ & 24.0 & \begin{tabular}{l|l}
7.0 \\
\end{tabular} & $\begin{array}{l}17.0 \\
\end{array}$ & 246.1 & $\begin{array}{l}44.4 \\
\end{array}$ & 22.6 \\
\hline $\min =$ & 0.10 & 0.00 & 0.00 & 0.00 & 0.00 & 0.28 & 0.01 & 0.00 & 0.00 & 0.00 & 6.64 & 1.43 & 0.38 & 6.1 & 1.6 & 1.3 & 10.2 & 1.5 & 0.4 \\
\hline mean $=$ & 1.73 & 7.22 & 3.04 & 6.13 & 4.19 & 2.89 & 0.65 & 6.19 & 0.54 & 0.20 & 16.69 & 2.78 & 1.25 & 15.0 & 4.6 & 2.9 & 59.8 & 9.5 & 4.0 \\
\hline median $=$ & 1.44 & 4.70 & 0.00 & 3.77 & 0.19 & 2.35 & 0.59 & 5.88 & 0.50 & 0.16 & 16.04 & 2.32 & 0.77 & 15.2 & 4.7 & 2.0 & 18.7 & 2.8 & 0.9 \\
\hline$s=$ & 1.44 & 9.20 & 5.04 & 6.91 & 6.93 & 2.04 & 0.61 & 4.90 & 0.55 & 0.20 & 7.56 & 1.72 & 2.10 & 5.0 & 2.0 & 3.9 & 81.5 & 17.1 & 6.1 \\
\hline$\% \mathrm{CV}=$ & 83.0 & 127.4 & 165.8 & 112.7 & 165.3 & 70.5 & 93.5 & 79.1 & 100.4 & 99.2 & 45.3 & 61.7 & 168.5 & 33.5 & 43.4 & 133.1 & 136.4 & 179.8 & 153.5 \\
\hline \multirow[t]{6}{*}{$n=$} & 19 & & & & 13 & 6 & 15 & & & & & & & & & & & & \\
\hline & & & & & & & & & & & & & & & & & & & \\
\hline & \multirow{2}{*}{\multicolumn{4}{|c|}{$\begin{array}{l}\text { Percent Reduction based on mean } \\
\text { runoff volume }(\mathrm{mm})\end{array}$}} & & & & & & & & & & & & & & & \\
\hline & & & & & & VO3-N (mg) & & & H44-N (mg & & & O4-P (mg) & & & TN (mg/L) & & & $\mathrm{TP}(\mathrm{mg} / \mathrm{L}$ & \\
\hline & & in-out & out - ctrl & in - ctrl & in - out & out - ctrl & in - ctrl & in - out & out - ctrl & in - ctrl & in - out & out - ctrl & in - ctrl & in - out & out - ctrl & in $-\mathrm{ctrl}$ & in - out & out - ctrl & in - ctrl \\
\hline & & $58 \%$ & $-102 \%$ & $15 \%$ & $31 \%$ & $78 \%$ & $85 \%$ & $91 \%$ & $62 \%$ & $97 \%$ & $83 \%$ & $55 \%$ & $93 \%$ & $69 \%$ & $37 \%$ & $80 \%$ & $84 \%$ & $58 \%$ & $93 \%$ \\
\hline
\end{tabular}

[a] " $\mathrm{n} / \mathrm{a}$ " indicates an error occurred in data collection and information was not included in analysis; "-_" indicates no sample was collected for the event 
Table A-6. Bell County load data

\begin{tabular}{|c|c|c|c|c|c|c|c|c|c|c|c|c|c|c|c|c|}
\hline \multirow{2}{*}{ Storm Date } & \multirow{2}{*}{$\begin{array}{c}\text { rainfall } \\
\text { (in) }\end{array}$} & \multicolumn{3}{|c|}{ NO3-N (kg/ha) } & \multicolumn{3}{|c|}{ NH4-N (kg/ha) } & \multicolumn{3}{|c|}{ PO4-P (kg/ha) } & \multicolumn{3}{|c|}{$\mathrm{TN}(\mathrm{kg} / \mathrm{ha})$} & \multicolumn{3}{|c|}{$\mathrm{TP}(\mathrm{kg} / \mathrm{ha})$} \\
\hline & & VTA In & VTA Out & Control & VTA In & VTA Out & Control & VTA In & VTA Out & Control & VTA In & VTA Out & Control & VTA In & VTA Out & Control \\
\hline $1 / 9 / 2013$ & 2.98 & 5.37 & 0.48 & 0.37 & 0.00 & 0.00 & 0.00 & 10.98 & 0.55 & 0.21 & $\overline{5.3}$ & 0.5 & 0.5 & 67.6 & 4.2 & 1.5 \\
\hline $2 / 10 / 2013$ & 1.64 & 1.15 & 0.00 & 0.27 & 0.00 & 0.00 & 0.00 & 1.41 & 0.00 & 0.11 & 1.0 & 0.0 & 0.4 & 9.7 & 0.0 & 0.8 \\
\hline $3 / 10 / 2013$ & 0.10 & 0.00 & 0.00 & 0.01 & 0.00 & 0.00 & 0.00 & 0.00 & 0.00 & 0.01 & 0.0 & 0.0 & 0.0 & 0.0 & 0.0 & 0.1 \\
\hline $5 / 16 / 2013$ & 2.00 & 0.01 & 0.18 & 0.06 & 2.26 & 0.12 & 0.01 & 3.88 & 0.15 & 0.04 & 3.5 & 0.4 & 0.1 & 4.4 & 0.2 & 0.0 \\
\hline $5 / 21 / 2013$ & 1.41 & 0.00 & 0.12 & 0.04 & 0.00 & 0.06 & 0.03 & 0.00 & 0.09 & 0.04 & 0.0 & 0.2 & 0.1 & 0.0 & 0.1 & 0.0 \\
\hline $7 / 14 / 2013$ & 0.66 & 0.00 & 0.00 & 0.00 & 0.84 & 0.00 & 0.00 & 1.25 & 0.00 & 0.00 & 1.3 & 0.0 & 0.0 & 1.3 & 0.0 & 0.0 \\
\hline $10 / 13 / 2013$ & 2.06 & $\mathrm{n} / \mathrm{a}$ & $\mathrm{n} / \mathrm{a}$ & $\mathrm{n} / \mathrm{a}$ & $\mathrm{n} / \mathrm{a}$ & $\mathrm{n} / \mathrm{a}$ & $\mathrm{n} / \mathrm{a}$ & $\mathrm{n} / \mathrm{a}$ & $\mathrm{n} / \mathrm{a}$ & $\mathrm{n} / \mathrm{a}$ & $\mathrm{n} / \mathrm{a}$ & $\mathrm{n} / \mathrm{a}$ & $\mathrm{n} / \mathrm{a}$ & $n / a$ & $\mathrm{n} / \mathrm{a}$ & $n / a$ \\
\hline $10 / 17 / 2013$ & 0.89 & 0.16 & 0.00 & 0.00 & 0.42 & 0.00 & 0.00 & 0.49 & 0.00 & 0.00 & 0.6 & 0.0 & 0.0 & 0.6 & 0.0 & 0.0 \\
\hline $10 / 27 / 2013$ & 1.24 & 0.00 & 0.00 & 0.02 & 0.37 & 0.00 & 0.02 & 1.02 & 0.00 & 0.04 & 0.8 & 0.0 & 0.1 & 1.2 & 0.0 & 0.0 \\
\hline $10 / 31 / 2013$ & 6.80 & $\mathrm{n} / \mathrm{a}$ & $\mathrm{n} / \mathrm{a}$ & $\mathrm{n} / \mathrm{a}$ & $\mathrm{n} / \mathrm{a}$ & $\mathrm{n} / \mathrm{a}$ & $\mathrm{n} / \mathrm{a}$ & $\mathrm{n} / \mathrm{a}$ & $\mathrm{n} / \mathrm{a}$ & $\mathrm{n} / \mathrm{a}$ & $\mathrm{n} / \mathrm{a}$ & $\mathrm{n} / \mathrm{a}$ & $\mathrm{n} / \mathrm{a}$ & $\mathrm{n} / \mathrm{a}$ & $\mathrm{n} / \mathrm{a}$ & $\mathrm{n} / \mathrm{a}$ \\
\hline $11 / 22 / 2013$ & 0.91 & 0.00 & 0.00 & 0.01 & 0.07 & 0.00 & 0.01 & 0.19 & 0.00 & 0.03 & 0.10 & 0.00 & 0.1 & 3.86 & 0.00 & 0.9 \\
\hline $4 / 6 / 2014$ & 1.60 & 3.14 & 0.89 & 0.24 & 0.00 & 0.00 & 0.00 & 5.48 & 0.50 & 0.09 & 3.8 & 1.1 & 0.3 & 5.8 & 0.7 & 0.2 \\
\hline $5 / 13 / 2014$ & 2.55 & 0.03 & 0.04 & 0.01 & 0.33 & 0.01 & 0.01 & 0.75 & 0.04 & 0.02 & 0.5 & 0.1 & 0.1 & 0.9 & 0.0 & 0.0 \\
\hline $5 / 27 / 2014$ & 1.44 & 0.00 & 0.00 & 0.01 & 0.19 & 0.00 & 0.01 & 0.21 & 0.00 & 0.02 & 0.4 & 0.0 & 0.1 & 0.2 & 0.0 & 0.0 \\
\hline $5 / 28 / 2014$ & 0.31 & 0.00 & 0.00 & 0.00 & 0.18 & 0.00 & 0.01 & 0.22 & 0.00 & 0.01 & 0.3 & 0.0 & 0.0 & 0.3 & 0.0 & 0.0 \\
\hline $6 / 10 / 2014$ & 1.32 & 0.01 & 0.00 & 0.00 & 0.09 & 0.00 & 0.01 & 0.21 & 0.00 & 0.02 & 0.4 & 0.0 & 0.1 & 0.5 & 0.0 & 0.0 \\
\hline $7 / 18 / 2014$ & 2.44 & 0.31 & 0.02 & 0.01 & 0.53 & 0.01 & 0.00 & 1.15 & 0.12 & 0.03 & 1.4 & 0.1 & 0.1 & 1.5 & 0.1 & 0.0 \\
\hline $10 / 13 / 2014$ & 0.94 & 0.00 & 0.00 & 0.01 & 0.00 & 0.00 & 0.02 & 0.00 & 0.00 & 0.05 & 0.0 & 0.0 & 0.2 & 0.0 & 0.0 & 0.1 \\
\hline $11 / 6 / 2014$ & 1.56 & 0.00 & 0.00 & 0.01 & 0.00 & 0.00 & 0.00 & 0.00 & 0.00 & 0.11 & 0.0 & 0.0 & 0.2 & 0.0 & 0.0 & 0.2 \\
\hline $\max =$ & 6.80 & 5.37 & 0.89 & 0.37 & 2.26 & 0.12 & 0.03 & 10.98 & 0.55 & 0.21 & 5.3 & 1.1 & $\overline{0.5}$ & 67.6 & 4.2 & 1.5 \\
\hline $\min =$ & 0.10 & 0.00 & 0.00 & 0.00 & 0.00 & 0.00 & 0.00 & 0.00 & 0.00 & 0.00 & 0.0 & 0.0 & 0.0 & 0.0 & 0.0 & 0.0 \\
\hline total $=$ & 32.85 & 10.16 & 1.73 & 1.08 & 5.29 & 0.20 & 0.13 & 27.25 & 1.46 & 0.83 & 19.3 & 2.5 & 2.2 & 97.8 & 5.3 & 3.9 \\
\hline mean $=$ & 1.73 & 0.60 & 0.10 & 0.06 & 0.31 & 0.01 & 0.01 & 1.60 & 0.09 & 0.05 & 1.1 & 0.1 & 0.1 & 5.8 & 0.3 & 0.2 \\
\hline median $=$ & 1.44 & 0.00 & 0.00 & 0.01 & 0.09 & 0.00 & 0.01 & 0.49 & 0.00 & 0.03 & 0.5 & 0.0 & 0.1 & 0.9 & 0.0 & 0.0 \\
\hline $\mathrm{s}=$ & 1.44 & 1.46 & 0.24 & 0.11 & 0.56 & 0.03 & 0.01 & 2.84 & 0.17 & 0.05 & 1.6 & 0.3 & 0.1 & 16.1 & 1.0 & 0.4 \\
\hline$\% C V=$ & 83.0 & 244.0 & 232.0 & 179.4 & 179.1 & 256.5 & 123.8 & 177.0 & 200.9 & 111.7 & 136.7 & 203.4 & 106.2 & 280.6 & 325.2 & 184.3 \\
\hline \multirow[t]{5}{*}{$\mathrm{n}=$} & 19 & & $x$ & $x$ & $x$ & 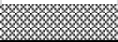 & $x$ & 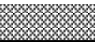 & $x$ & $x$ & 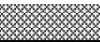 & x & . & & $x$ & $x$ \\
\hline & & \multicolumn{3}{|c|}{ Percent Reduction based on total } & & & & & & & & & & & & \\
\hline & & \multicolumn{3}{|c|}{ NO3-N (kg/ha) } & \multicolumn{3}{|c|}{ NH4-N (kg/ha) } & \multicolumn{3}{|c|}{ PO4-P (kg/ha) } & \multicolumn{3}{|c|}{$\mathrm{TN}$ (kg/ha) } & \multicolumn{3}{|c|}{$\mathrm{TP}(\mathrm{kg} / \mathrm{ha})$} \\
\hline & & in - out & out - ctrl & in - ctrl & in - out & out - ctrl & in - ctrl & in - out & out - ctrl & in - ctrl & in - out & out - ctrl & in - ctrl & in - out & out - ctrl & in - ctrl \\
\hline & & $83 \%$ & $37 \%$ & $89 \%$ & $96 \%$ & $38 \%$ & $98 \%$ & $95 \%$ & $43 \%$ & $97 \%$ & $87 \%$ & $11 \%$ & $88 \%$ & $95 \%$ & $27 \%$ & $96 \%$ \\
\hline
\end{tabular}

[a] " $\mathrm{n} / \mathrm{a}$ " indicates an error occurred in data collection and information was not included in analysis; "-" indicates no sample was collected for the event 
Table A-7. Brazos County concentration data

\begin{tabular}{|c|c|c|c|c|c|c|c|c|c|c|c|c|c|c|c|c|c|c|c|}
\hline \multirow{2}{*}{ Storm Date } & \multirow{2}{*}{$\begin{array}{l}\text { rainfall } \\
\text { (in) } \\
\end{array}$} & \multicolumn{3}{|c|}{ runoff volume $(\mathrm{mm})$} & \multicolumn{3}{|c|}{ NO3-N $(\mathrm{mg} / \mathrm{L})$} & \multicolumn{3}{|c|}{$\mathrm{NH} 4-\mathrm{N}(\mathrm{mg} / \mathrm{L})$} & \multicolumn{3}{|c|}{ PO4-P (mg/L) } & \multicolumn{3}{|c|}{$\mathrm{TN}(\mathrm{mg} / \mathrm{L})$} & \multicolumn{3}{|c|}{$\mathrm{TP}(\mathrm{mg} / \mathrm{L})$} \\
\hline & & VTA In & VTA Out & Control & VTA In & VTA Out & Control & VTA In & VTA Out & Control & VTA In & VTA Out & Control & VTA In & VTA Out & Control & VTA In & VTA Out & Control \\
\hline 1/9/2013 & 3.97 & 82.87 & 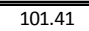 & 12.75 & 11.41 & 1.37 & 0.75 & 0.00 & 0.01 & 0.00 & 0.92 & 0.50 & 0.21 & 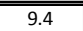 & 2.1 & 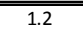 & 9.3 & "6.8 & 3.0 \\
\hline $5 / 9 / 2013$ & 2.64 & 10.76 & 1.68 & 0.00 & 3.06 & 0.03 & - & 16.11 & 6.42 & - & 12.11 & 3.23 & - & 21.7 & 7.5 & - & 14.7 & 3.8 & - \\
\hline $5 / 16 / 2013$ & 0.19 & 33.80 & 22.09 & 2.20 & 0.00 & 1.02 & 0.34 & 46.10 & 15.70 & 0.21 & 33.66 & 7.99 & 0.60 & 30.8 & 15.9 & 1.5 & 28.7 & 9.0 & 0.7 \\
\hline $5 / 21 / 2013$ & 2.83 & 63.39 & 55.94 & 10.12 & 1.52 & 2.03 & 0.36 & 11.33 & 0.89 & 0.54 & 12.80 & 2.75 & 0.62 & 18.6 & 3.3 & 1.9 & 17.1 & 2.8 & 0.7 \\
\hline $6 / 2 / 2013$ & 1.02 & 6.10 & 3.39 & 0.00 & 14.48 & 0.27 & & 3.53 & 0.40 & & 7.37 & 0.97 & - & 14.4 & 1.6 & - & 7.7 & 1.2 & \\
\hline 9/28/2013 & 4.65 & 106.62 & 57.23 & 12.54 & 11.31 & 1.42 & 0.54 & 11.05 & 0.74 & 0.14 & 7.91 & 1.07 & 0.28 & 19.1 & 4.6 & 1.3 & 10.4 & 2.1 & 0.3 \\
\hline $10 / 13 / 2013$ & 2.20 & 30.66 & 25.64 & 8.24 & 14.54 & 2.20 & 0.20 & 6.03 & 0.56 & 0.33 & 7.85 & 1.13 & 0.36 & 18.6 & 3.7 & 1.6 & 9.9 & 1.5 & 0.5 \\
\hline $10 / 27 / 2013$ & $\mathrm{n} / \mathrm{a}$ & $\mathrm{n} / \mathrm{a}$ & $\mathrm{n} / \mathrm{a}$ & $\mathrm{n} / \mathrm{a}$ & $\mathrm{n} / \mathrm{a}$ & $\mathrm{n} / \mathrm{a}$ & $\mathrm{n} / \mathrm{a}$ & $\mathrm{n} / \mathrm{a}$ & $\mathrm{n} / \mathrm{a}$ & $\mathrm{n} / \mathrm{a}$ & $\mathrm{n} / \mathrm{a}$ & $\mathrm{n} / \mathrm{a}$ & $\mathrm{n} / \mathrm{a}$ & $\mathrm{n} / \mathrm{a}$ & $\mathrm{n} / \mathrm{a}$ & $\mathrm{n} / \mathrm{a}$ & $\mathrm{n} / \mathrm{a}$ & $\mathrm{n} / \mathrm{a}$ & $\mathrm{n} / \mathrm{a}$ \\
\hline $10 / 31 / 2013$ & 1.62 & 103.30 & 32.07 & 15.09 & 0.00 & 0.04 & 0.00 & 38.96 & 9.63 & 0.21 & 16.97 & 5.90 & 0.54 & 29.9 & 12.1 & 1.7 & 24.2 & 7.9 & 0.4 \\
\hline $11 / 6 / 2013$ & 1.05 & 7.72 & 10.11 & 8.98 & 0.00 & 0.35 & 0.00 & 79.00 & 5.54 & 0.33 & 17.79 & 4.23 & 0.57 & 31.9 & 9.2 & 2.1 & 25.2 & 5.7 & 0.4 \\
\hline $11 / 22 / 2013$ & 0.70 & 22.24 & 20.17 & 3.61 & 0.00 & 1.24 & 0.00 & 45.57 & 4.57 & 0.15 & 15.69 & 4.36 & 0.41 & 31.4 & 7.0 & 1.4 & 21.4 & 5.8 & 1.0 \\
\hline $11 / 24 / 2013$ & 0.27 & 0.00 & 6.73 & 1.50 & 0.00 & 0.63 & 0.00 & 年 & 3.19 & 0.03 & - & 3.68 & 0.35 & & 5.7 & 1.5 & & 133.4 & 5.3 \\
\hline $11 / 26 / 2013$ & 1.11 & 35.49 & 35.35 & 7.32 & 0.38 & 0.73 & 0.00 & 42.23 & 8.88 & 0.05 & 9.33 & 3.74 & 0.37 & 28.7 & 10.0 & 1.0 & 452.5 & 303.9 & 63.5 \\
\hline $1 / 10 / 2014$ & 0.99 & 0.00 & 6.73 & 1.74 & $x_{1}$ & 17.20 & 0.93 & -2 & 0.09 & 0.00 & - & 2.99 & 0.38 & $x_{1}$ & 26.1 & 2.5 & - & 4.7 & 0.5 \\
\hline $3 / 9 / 2014$ & 0.64 & 13.79 & 3.38 & 0.00 & 0.00 & 17.54 & & 79.97 & 2.59 & 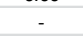 & 28.92 & 6.94 & - & 98.1 & 31.4 & - & 37.1 & 8.1 & \\
\hline $5 / 13 / 2014$ & 3.70 & 49.22 & 45.43 & 4.84 & 0.14 & 0.36 & 0.03 & 17.75 & 8.96 & 0.74 & 16.19 & 5.44 & 0.59 & 25.4 & 8.3 & 1.2 & 20.5 & 5.9 & 0.6 \\
\hline $5 / 27 / 2014$ & 1.93 & 18.46 & 1.68 & 3.96 & 0.00 & 0.00 & 0.05 & 33.67 & 1.14 & 0.17 & 17.34 & 1.76 & 0.39 & 43.5 & 6.2 & 3.2 & 21.0 & 3.4 & 0.4 \\
\hline $5 / 28 / 2014$ & 0.54 & 10.49 & 8.41 & 0.00 & 0.00 & 0.26 & - & 40.87 & 3.44 & - & 25.16 & 2.99 & - & 48.4 & 6.9 & - & 28.6 & 3.2 & - \\
\hline $6 / 10 / 2014$ & 1.22 & 13.90 & 0.00 & 0.00 & 0.00 & & - & 35.36 & & - & 22.75 & - & - & 49.8 & & - & 28.3 & - & - \\
\hline 6/26/2014 & 2.93 & 20.50 & 34.24 & 7.46 & 0.35 & 0.74 & 0.11 & 11.68 & 2.06 & 0.11 & 9.13 & 3.20 & 0.50 & 18.8 & 6.8 & 1.7 & 12.4 & 3.9 & 0.6 \\
\hline 6/27/2014 & (2) & 1.54 & 0.00 & 0.00 & 0.00 & - & - & 68.80 & - & - & 40.10 & - & - & 75.7 & - & - & 48.1 & - & - \\
\hline $7 / 18 / 2014$ & 3.02 & 27.98 & 28.74 & 4.40 & 2.24 & 0.70 & 0.08 & 6.53 & 1.18 & 0.00 & 8.98 & 3.13 & 0.43 & 17.2 & 3.8 & 1.6 & 48.1 & 3.9 & 0.4 \\
\hline $9 / 13 / 2014$ & 2.60 & 13.90 & 6.88 & 0.88 & 3.66 & 0.1615 & 0.0518 & 4.29 & 0.0012 & 0.06 & 11.61 & 1.30 & 0.50 & 11.8 & 1.5 & 1.1 & 12.7 & 2.0 & 1.2 \\
\hline $11 / 6 / 2014$ & 3.16 & 1.54 & 8.47 & 2.64 & 34.96 & 8.99 & 2.17 & 41.60 & 0.17 & 0.03 & 115.75 & 26.16 & 4.73 & 117.2 & 35.0 & 24.1 & 113.0 & 29.6 & 6.8 \\
\hline $\max =$ & 4.65 & 106.62 & 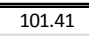 & 15.09 & $\begin{array}{l}34.96 \\
\end{array}$ & $\begin{array}{ll}17.54 \\
\end{array}$ & 2.17 & $\begin{array}{l}79.97 \\
\end{array}$ & $\begin{array}{l}15.70 \\
\end{array}$ & 0.74 & $\begin{array}{l}115.75 \\
\end{array}$ & $\begin{array}{l}26.16 \\
\end{array}$ & 4.73 & \begin{tabular}{c|}
117.2 \\
\end{tabular} & 35.0 & 24.1 & $\begin{array}{c}452.5 \\
\end{array}$ & 303.9 & (63.5 \\
\hline $\min =$ & 0.19 & 0.00 & 0.00 & 0.00 & 0.00 & 0.00 & 0.00 & 0.00 & 0.00 & 0.00 & 0.92 & 0.50 & 0.21 & 9.4 & 1.5 & 1.0 & 7.7 & 1.2 & 0.3 \\
\hline mean $=$ & 1.95 & 29.32 & 22.43 & 4.71 & 4.67 & 2.73 & 0.33 & 30.50 & 3.63 & 0.18 & 20.87 & 4.45 & 0.69 & $\begin{array}{l}36.2 \\
36.2\end{array}$ & 9.9 & 3.0 & 47.2 & 26.1 & 5.1 \\
\hline median $=$ & 1.78 & 18.46 & 10.11 & 3.61 & 0.35 & 0.73 & 0.08 & 33.67 & 2.06 & 0.14 & 15.69 & 3.20 & 0.43 & 28.7 & 6.9 & 1.6 & 21.4 & 4.7 & 0.6 \\
\hline$s=$ & 1.29 & 31.52 & 24.70 & 4.71 & 8.59 & 5.23 & 0.55 & 24.70 & 4.20 & 0.20 & 23.74 & 5.35 & 1.05 & 28.5 & 9.5 & 5.5 & 95.6 & 69.7 & 15.2 \\
\hline$\% \mathrm{CV}=$ & 66.0 & 107.5 & 110.2 & 100.0 & 183.9 & 191.6 & 167.8 & 81.0 & 115.7 & 112.8 & 113.7 & 120.3 & 150.4 & 78.6 & 95.7 & 183.7 & 202.7 & 266.9 & 298.9 \\
\hline \multirow[t]{5}{*}{$\mathrm{n}=$} & 22 & & & & 21 & 21 & 17 & & & & & & & & & & & & \\
\hline & & & & & & & & & & & & & & & & & & & \\
\hline & & Percent R & fuction bas & on mean & & 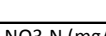 & & & $\mathrm{NH} 4 \mathrm{~N} / \mathrm{m}$ & & & $8 / 1 / 1$ & & & TN/m & & & $T$ (m) & \\
\hline & & in - out & $\begin{array}{l}\text { off volume } \\
\text { out - ctrl }\end{array}$ & $\begin{array}{l}\text { nm) } \\
\text { in - ctrl }\end{array}$ & in - out & out - ctrl & in - ctrl & in - out & out - ctrl & in - ctrl & in - out & out - ctrl & in - ctrl & in - out & out - ctrl & in - ctrl & in - out & out - ctrl & in - ctrl \\
\hline & & $24 \%$ & $79 \%$ & $84 \%$ & $42 \%$ & $88 \%$ & $93 \%$ & $88 \%$ & $95 \%$ & $99 \%$ & $79 \%$ & $84 \%$ & $97 \%$ & $73 \%$ & $70 \%$ & $92 \%$ & $45 \%$ & $81 \%$ & $89 \%$ \\
\hline
\end{tabular}

[a] " $\mathrm{n} / \mathrm{a}$ " indicates an error occurred in data collection and information was not included in analysis; "-“ indicates no sample was collected for the event 
Table A-8. Brazos County load data

\begin{tabular}{|c|c|c|c|c|c|c|c|c|c|c|c|c|c|c|c|c|}
\hline \multirow{2}{*}{ Storm Date } & \multirow{2}{*}{$\begin{array}{c}\text { rainfall } \\
\text { (in) }\end{array}$} & \multicolumn{3}{|c|}{ NO3-N (kg/ha) } & \multicolumn{3}{|c|}{ NH4-N (kg/ha) } & \multicolumn{3}{|c|}{ PO4-P (kg/ha) } & \multicolumn{3}{|c|}{$\mathrm{TN}$ (kg/ha) } & \multicolumn{3}{|c|}{$\mathrm{TP}$ (kg/ha) } \\
\hline & & VTA In & VTA Out & Control & VTA In & VTA Out & Control & VTA In & VTA Out & Control & VTA In & VTA Out & Control & VTA In & VTA Out & Control \\
\hline |1/9/2013 & $\begin{array}{l}.97 \\
.97\end{array}$ & 9.45 & 1.38 & $\bar{~} 0.10$ & (0.00 & 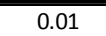 & 0.00 & 0.76 & 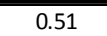 & 0.03 & 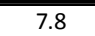 & 2.1 & 0.1 & 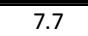 & 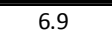 & 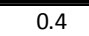 \\
\hline $5 / 9 / 2013$ & 2.64 & 0.33 & 0.00 & 0.00 & 1.73 & 0.11 & 0.00 & 1.30 & 0.05 & 0.00 & 2.3 & 0.1 & 0.0 & 1.6 & 0.1 & 0.0 \\
\hline $5 / 16 / 2013$ & 0.19 & 0.00 & 0.22 & 0.01 & 15.58 & 3.47 & 0.00 & 11.38 & 1.76 & 0.01 & 10.4 & 3.5 & 0.0 & 9.7 & 2.0 & 0.0 \\
\hline $5 / 21 / 2013$ & 2.83 & 0.96 & 1.13 & 0.04 & 7.18 & 0.50 & 0.05 & 8.11 & 1.54 & 0.06 & 11.8 & 1.8 & 0.2 & 10.8 & 1.6 & 0.1 \\
\hline 6/2/2013 & 1.02 & 0.88 & 0.01 & 0.00 & 0.22 & 0.01 & 0.00 & 0.45 & 0.03 & 0.00 & 0.9 & 0.1 & 0.0 & 0.5 & 0.0 & 0.0 \\
\hline 9/28/2013 & 4.65 & 12.06 & 0.81 & 0.07 & 11.78 & 0.42 & 0.02 & 8.43 & 0.61 & 0.04 & 20.3 & 2.7 & 0.2 & 11.1 & 1.2 & 0.0 \\
\hline $10 / 13 / 2013$ & 2.20 & 4.46 & 0.56 & 0.02 & 1.85 & 0.14 & 0.03 & 2.41 & 0.29 & 0.03 & 5.7 & 0.9 & 0.1 & 3.0 & 0.4 & 0.0 \\
\hline $10 / 27 / 2013$ & $n / a$ & $n / a$ & $n / a$ & $n / a$ & $n / a$ & $n / a$ & $n / a$ & $n / a$ & $n / a$ & $n / a$ & $n / a$ & $n / a$ & $n / a$ & $n / a$ & $n / a$ & $n / a$ \\
\hline $10 / 31 / 2013$ & 1.62 & 0.00 & 0.01 & 0.00 & 40.25 & 3.09 & 0.03 & 17.53 & 1.89 & 0.08 & 30.9 & 3.9 & 0.3 & 25.0 & 2.5 & 0.1 \\
\hline $11 / 6 / 2013$ & 1.05 & 0.00 & 0.04 & 0.00 & 6.10 & 0.56 & 0.03 & 1.37 & 0.43 & 0.05 & 2.5 & 0.9 & 0.2 & 1.9 & 0.6 & 0.0 \\
\hline $11 / 22 / 2013$ & 0.70 & 0.00 & 0.25 & 0.00 & 10.13 & 0.92 & 0.01 & 3.49 & 0.88 & 0.01 & 7.0 & 1.4 & 0.1 & 4.8 & 1.2 & 0.0 \\
\hline $11 / 24 / 2013$ & 0.27 & 0.00 & 0.04 & 0.00 & 0.00 & 0.21 & 0.00 & 0.00 & 0.25 & 0.01 & 0.00 & 0.39 & 0.02 & 0.00 & 8.98 & 0.08 \\
\hline $11 / 26 / 2013$ & 1.11 & 0.13 & 0.26 & 0.00 & 14.99 & 3.14 & 0.00 & 3.31 & 1.32 & 0.03 & 10.2 & 3.5 & 0.1 & 160.6 & 107.4 & 4.7 \\
\hline $1 / 10 / 2014$ & 0.99 & 0.00 & 1.16 & 0.02 & 0.00 & 0.01 & 0.00 & 0.00 & 0.20 & 0.01 & 0.0 & 1.8 & 0.0 & 0.0 & 0.3 & 0.0 \\
\hline $3 / 9 / 2014$ & 0.64 & 0.00 & 0.59 & 0.00 & 11.03 & 0.09 & 0.00 & 3.99 & 0.23 & 0.00 & 13.5 & 1.1 & 0.0 & 5.1 & 0.3 & 0.0 \\
\hline $5 / 13 / 2014$ & 3.70 & 0.07 & 0.16 & 0.00 & 8.74 & 4.07 & 0.04 & 7.97 & 2.47 & 0.03 & 12.5 & 3.8 & 0.1 & 10.1 & 2.7 & 0.0 \\
\hline $5 / 27 / 2014$ & 1.93 & 0.00 & 0.00 & 0.00 & 6.22 & 0.02 & 0.01 & 3.20 & 0.03 & 0.02 & 8.0 & 0.1 & 0.1 & 3.9 & 0.1 & 0.0 \\
\hline $5 / 28 / 2014$ & 0.54 & 0.00 & 0.02 & 0.00 & 4.29 & 0.29 & 0.00 & 2.64 & 0.25 & 0.00 & 5.1 & 0.6 & 0.0 & 3.0 & 0.3 & 0.0 \\
\hline $6 / 10 / 2014$ & 1.22 & 0.00 & 0.00 & 0.00 & 4.92 & 0.00 & 0.00 & 3.16 & 0.00 & 0.00 & 6.9 & 0.0 & 0.0 & 3.9 & 0.0 & 0.0 \\
\hline $6 / 26 / 2014$ & 2.93 & 0.07 & 0.25 & 0.01 & 2.39 & 0.71 & 0.01 & 1.87 & 1.10 & 0.04 & 3.9 & 2.3 & 0.1 & 2.5 & 1.3 & 0.0 \\
\hline $6 / 27 / 2014$ & - & 0.00 & 0.00 & 0.00 & 1.06 & 0.00 & 0.00 & 0.62 & 0.00 & 0.00 & 1.2 & 0.0 & 0.0 & 0.7 & 0.0 & 0.0 \\
\hline $7 / 18 / 2014$ & 3.02 & 0.63 & 0.20 & 0.00 & 1.83 & 0.34 & 0.00 & 2.51 & 0.90 & 0.02 & 4.8 & 1.1 & 0.1 & 13.5 & 1.1 & 0.0 \\
\hline 9/13/2014 & 2.60 & 0.51 & 0.01 & 0.00 & 0.60 & 0.00 & 0.00 & 1.61 & 0.09 & 0.00 & 1.6 & 0.1 & 0.0 & 1.8 & 0.1 & 0.0 \\
\hline $11 / 6 / 2014$ & 3.16 & 0.54 & 0.76 & 0.06 & 0.64 & 0.01 & 0.00 & 1.78 & 2.21 & 0.12 & 1.8 & 3.0 & 0.6 & 1.7 & 2.5 & 0.2 \\
\hline max $=$ & 4 & "12.06 & 1.38 & 0.10 & (40.25 & $\begin{array}{l}4.07 \\
\end{array}$ & 0.05 & 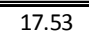 & 2.47 & 0.12 & 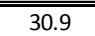 & 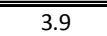 & 0.6 & ב160.6 & $\begin{array}{l}107.4 \\
\end{array}$ & 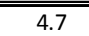 \\
\hline $\min =$ & 0.19 & 0.00 & 0.00 & 0.00 & 0.00 & 0.00 & 0.00 & 0.00 & 0.00 & 0.00 & 0.0 & 0.0 & 0.0 & 0.0 & 0.0 & 0.0 \\
\hline total $=$ & 42.98 & 30.09 & 7.89 & 0.31 & 151.52 & 18.12 & 0.23 & 87.91 & 17.06 & 0.58 & 169.1 & 35.2 & 2.3 & 283.0 & 141.5 & 5.7 \\
\hline mean $=$ & 1.95 & 1.31 & 0.34 & 0.01 & 6.59 & 0.79 & 0.01 & 3.82 & 0.74 & 0.03 & 7.4 & 1.5 & 0.1 & 12.3 & 6.2 & 0.2 \\
\hline median $=$ & 1.78 & 0.07 & 0.20 & 0.00 & 4.29 & 0.21 & 0.00 & 2.51 & 0.43 & 0.02 & 5.7 & 1.1 & 0.1 & 3.9 & 1.1 & 0.0 \\
\hline $\mathrm{s}=$ & 1.29 & 3.15 & 0.43 & 0.03 & 8.83 & 1.28 & 0.02 & 4.23 & 0.77 & 0.03 & 7.2 & 1.3 & 0.1 & 32.8 & 22.2 & 1.0 \\
\hline$\% \mathrm{CV}=$ & 66.0 & 240.6 & 125.2 & 190.5 & 134.1 & 162.5 & 155.3 & 110.7 & 104.0 & 121.3 & 98.5 & 87.2 & 136.8 & 267.0 & 360.7 & 387.7 \\
\hline \multirow[t]{5}{*}{$n=$} & 22 & & & & & & & & & & & & & & & \\
\hline & & \multicolumn{3}{|c|}{ Percent Reduction based on total } & & & & & & & & & & & & \\
\hline & & \multicolumn{3}{|c|}{ NO3-N (kg/ha) } & \multicolumn{3}{|c|}{ NH4-N (kg/ha) } & \multicolumn{3}{|c|}{ PO4-P (kg/ha) } & \multicolumn{3}{|c|}{$\mathrm{TN}$ (kg/ha) } & \multicolumn{3}{|c|}{$\mathrm{TP}(\mathrm{kg} / \mathrm{ha})$} \\
\hline & & in - out & out - ctrl & in - ctrl & in - out & out - ctrl & in - ctrl & in - out & out - ctrl & in - ctrl & in - out & out - ctrl & in - ctrl & in - out & out -ctrl & in - ctrl \\
\hline & & $74 \%$ & $96 \%$ & $99 \%$ & $88 \%$ & $99 \%$ & $100 \%$ & $81 \%$ & $97 \%$ & $99 \%$ & $79 \%$ & $93 \%$ & $99 \%$ & $50 \%$ & $96 \%$ & $98 \%$ \\
\hline
\end{tabular}

[a] " $\mathrm{n} / \mathrm{a}$ " indicates an error occurred in data collection and information was not included in analysis; "-“ indicates no sample was collected for the event 
Table A-9. Robertson County concentration data

\begin{tabular}{|c|c|c|c|c|c|c|c|c|c|c|c|c|c|c|c|c|c|c|c|}
\hline \multirow{2}{*}{ Storm Date } & \multirow{2}{*}{$\begin{array}{l}\text { rainfall } \\
\text { (in) }\end{array}$} & \multicolumn{3}{|c|}{ runoff volume $(\mathrm{mm})$} & \multicolumn{3}{|c|}{ NO3-N (mg/L) } & \multicolumn{3}{|c|}{ NH4-N (mg/L) } & \multicolumn{3}{|c|}{ PO4-P (mg/L) } & \multicolumn{3}{|c|}{ TN (mg/L) } & \multicolumn{3}{|c|}{ TP (mg/L) } \\
\hline & & VTA In & VTA Out & Control & VTA In & VTA Out & Control & VTA In & VTA Out & Control & VTA In & VTA Out & Control & VTA In & VTA Out & Control & VTA In & VTA Out & Control \\
\hline 1/9/2013 & 3.16 & 9.22 & $\overline{c 15.76}$ & 0.00 & 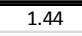 & 0.42 & & 0.00 & 0.00 & - & 0.51 & 0.13 & & 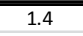 & 0.8 & 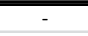 & 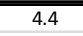 & 22.7 & $=$ \\
\hline $3 / 10 / 2013$ & 1.62 & 4.02 & 2.67 & 1.32 & 1.30 & 0.42 & 0.03 & 0.00 & 0.03 & 0.84 & 0.75 & 0.15 & 0.05 & 1.5 & 0.9 & 1.3 & 6.6 & 2.0 & 0.8 \\
\hline $4 / 3 / 2013$ & 2.67 & 17.12 & 3.64 & 0.00 & 0.92 & 0.43 & & 0.00 & 0.00 & & 0.32 & 0.08 & & 1.1 & 0.9 & - & 3.5 & 1.6 & - \\
\hline $5 / 9 / 2013$ & 2.63 & 46.10 & 35.70 & 17.15 & 1.33 & 0.59 & 0.72 & 0.83 & 0.48 & 0.04 & 1.38 & 0.87 & 0.06 & 2.8 & 2.0 & 1.5 & 1.7 & 1.0 & 0.3 \\
\hline $5 / 16 / 2013$ & 1.53 & 6.62 & 4.93 & 0.00 & 0.23 & 0.01 & - & 10.34 & 0.23 & - & 2.10 & 0.16 & 0 & 8.9 & 1.2 & - & 2.2 & 0.1 & - \\
\hline $5 / 21 / 2013$ & 2.03 & 40.29 & 27.11 & 2.63 & 1.08 & 0.49 & 0.12 & 0.35 & 0.01 & 2.56 & 0.43 & 0.17 & 0.15 & 1.6 & 1.5 & 6.0 & 0.6 & 0.3 & 0.0 \\
\hline 6/2/2013 & 0.99 & 2.72 & 0.00 & 0.00 & 0.12 & - & - & 0.06 & - & - & 0.00 & - & 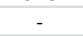 & 0.3 & - & - & 0.0 & - & - \\
\hline $7 / 14 / 2013$ & 0.86 & 3.60 & 0.00 & 0.00 & 0.13 & - & - & 0.11 & - & - & 0.18 & - & - & 1.9 & - & - & 0.3 & - & - \\
\hline $9 / 28 / 2013$ & 1.36 & 13.21 & 0.00 & 0.00 & 0.03 & - & - & 0.05 & - & - & 0.19 & - & - & 0.3 & - & - & 0.2 & - & - \\
\hline $10 / 13 / 2013$ & - & $n / a$ & $n / a$ & $n / a$ & n/a & $n / a$ & $\mathrm{n} / \mathrm{a}$ & $n / a$ & $\mathrm{n} / \mathrm{a}$ & $n / a$ & $n / a$ & $\mathrm{n} / \mathrm{a}$ & $\mathrm{n} / \mathrm{a}$ & $n / a$ & $n / a$ & $n / a$ & $\mathrm{n} / \mathrm{a}$ & $n / a$ & n/a \\
\hline $10 / 27 / 2013$ & - & $n / a$ & $n / a$ & n/a & n/a & n/a & $n / a$ & $n / a$ & $n / a$ & $\mathrm{n} / \mathrm{a}$ & $n / a$ & $n / a$ & $n / a$ & n/a & n/a & $\mathrm{n} / \mathrm{a}$ & $n / a$ & $n / a$ & n/a \\
\hline $10 / 31 / 2013$ & - & $n / a$ & $n / a$ & n/a & n/a & $n / a$ & $n / a$ & $n / a$ & $n / a$ & $\mathrm{n} / \mathrm{a}$ & n/a & $n / a$ & $n / a$ & n/a & n/a & $\mathrm{n} / \mathrm{a}$ & $\mathrm{n} / \mathrm{a}$ & $n / a$ & n/a \\
\hline $11 / 22 / 2013$ & & 1.32 & 0.00 & 0.00 & 0.03 & - & 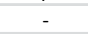 & 0.16 & 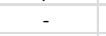 & - & 0.34 & - & 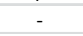 & 1.3 & 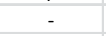 & - & 0.1 & - & - \\
\hline $5 / 27 / 2014$ & 2.36 & 1.32 & 0.00 & 0.00 & 0.30 & - & 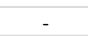 & 0.11 & - & - & 0.61 & - & - & 1.9 & - & - & 1.0 & - & - \\
\hline $5 / 28 / 2014$ & & $\mathrm{n} / \mathrm{a}$ & $\mathrm{n} / \mathrm{a}$ & n/a & n/a & $n / a$ & $\mathrm{n} / \mathrm{a}$ & $n / a$ & $\mathrm{n} / \mathrm{a}$ & $n / a$ & $\mathrm{n} / \mathrm{a}$ & $\mathrm{n} / \mathrm{a}$ & $\mathrm{n} / \mathrm{a}$ & $n / a$ & $n / a$ & $n / a$ & $n / a$ & $\mathrm{n} / \mathrm{a}$ & $n / a$ \\
\hline $6 / 10 / 2014$ & 1.70 & 3.92 & 0.00 & 0.00 & 0.27 & - & - & 1.55 & - & - & 1.11 & - & - & 3.2 & - & - & 0.9 & - & - \\
\hline 9/19/2014 & 1.88 & 1.32 & 0.00 & 0.00 & 0.00 & - & - & 0.01 & - & - & 0.40 & - & - & 0.7 & - & - & 1.1 & - & - \\
\hline $10 / 13 / 2014$ & 1.21 & 1.32 & 0.00 & 0.00 & 0.06 & - & - & 0.05 & - & - & 0.60 & - & - & 0.8 & - & - & 1.1 & - & - \\
\hline $\max =$ & 3.16 & 46.10 & 35.70 & 17.15 & 1.44 & 0.59 & 0.72 & 10.34 & 0.48 & 2.56 & 2.10 & 0.87 & 0.15 & 8.9 & 2.0 & 6.0 & 6.6 & 2.7 & 0.8 \\
\hline $\min =$ & 0.86 & 1.32 & 0.00 & 0.00 & 0.00 & 0.01 & 0.03 & 0.00 & 0.00 & 0.04 & 0.00 & 0.08 & 0.05 & 0.3 & 0.8 & 1.3 & 0.0 & 0.1 & 0.0 \\
\hline mean $=$ & 1.85 & 10.86 & 6.42 & 1.51 & 0.52 & 0.39 & 0.29 & 0.97 & 0.12 & 1.14 & 0.64 & 0.26 & 0.08 & 2.0 & 1.2 & 2.9 & 1.7 & 1.3 & 0.3 \\
\hline median $=$ & 1.70 & 3.97 & 0.00 & 0.00 & 0.25 & 0.42 & 0.12 & 0.08 & 0.02 & 0.84 & 0.47 & 0.15 & 0.06 & 1.4 & 1.1 & 1.5 & 1.0 & 1.3 & 0.3 \\
\hline$s=$ & 0.70 & 14.55 & 11.52 & 4.56 & 0.56 & 0.20 & 0.38 & 2.73 & 0.20 & 1.29 & 0.56 & 0.30 & 0.05 & 2.2 & 0.5 & 2.7 & 1.9 & 1.0 & 0.4 \\
\hline$\% \mathrm{CV}=$ & 37.8 & 133.9 & 179.6 & 302.9 & 108.0 & 50.5 & 131.6 & 280.9 & 157.8 & 112.6 & 87.6 & 116.0 & 64.7 & 109.6 & 37.3 & 92.7 & 113.8 & 79.0 & 109.4 \\
\hline \multirow[t]{6}{*}{$n=$} & 13 & 14 & 14 & 14 & 14 & 6 & 3 & & & & & & & & & & & & \\
\hline & & & & & & & & & & & & & & & & & & & \\
\hline & & \multicolumn{3}{|c|}{ Percent Reduction based on mean } & & & & & & & & & & & & & & & \\
\hline & & \multicolumn{3}{|c|}{ runoff volume $(\mathrm{mm})$} & \multicolumn{3}{|c|}{ NO3-N (mg/L) } & \multicolumn{3}{|c|}{$\mathrm{NH4-N} \mathrm{(mg/L)}$} & \multicolumn{3}{|c|}{ PO4-P (mg/L) } & \multicolumn{3}{|c|}{$\mathrm{TN}(\mathrm{mg} / \mathrm{L})$} & \multicolumn{3}{|c|}{$\mathrm{TP}(\mathrm{mg} / \mathrm{L})$} \\
\hline & & in - out & out -ctrl & in - ctrl & in - out & out - ctrl & in - ctrl & in - out & out -ctrl & in $-\mathrm{ctrl}$ & in-out & out $-\mathrm{ctrl}$ & in $-\mathrm{ctrl}$ & in - out & out - ctrl & in - ctrl & in - out & out - ctrl & in - ctrl \\
\hline & & $41 \%$ & $77 \%$ & $86 \%$ & $24 \%$ & $27 \%$ & $45 \%$ & $87 \%$ & $-825 \%$ & $-18 \%$ & $59 \%$ & $68 \%$ & $87 \%$ & $38 \%$ & $-139 \%$ & $-47 \%$ & $25 \%$ & $73 \%$ & $79 \%$ \\
\hline
\end{tabular}

[a] " $\mathrm{n} / \mathrm{a}$ " indicates an error occurred in data collection and information was not included in analysis; "-_" indicates no sample was collected for the event 
Table A-10. Robertson County load data

\begin{tabular}{|c|c|c|c|c|c|c|c|c|c|c|c|c|c|c|c|c|}
\hline \multirow{2}{*}{ Storm Date } & \multirow{2}{*}{$\begin{array}{c}\text { rainfall } \\
\text { (in) }\end{array}$} & \multicolumn{3}{|c|}{ NO3-N (kg/ha) } & \multicolumn{3}{|c|}{ NH4-N (kg/ha) } & \multicolumn{3}{|c|}{ PO4-P (kg/ha) } & \multicolumn{3}{|c|}{$\mathrm{TN}$ (kg/ha) } & \multicolumn{3}{|c|}{$\mathrm{TP}$ (kg/ha) } \\
\hline & & VTA In & VTA Out & Control & VTA In & VTA Out & Control & VTA In & VTA Out & Control & VTA In & VTA Out & Control & VTA In & VTA Out & Control \\
\hline 1/9/2013 & 3.16 & 0.13 & 0.07 & 0.00 & 0.00 & 0.00 & 0.00 & 0.05 & 0.02 & 0.00 & 0.1 & 0.1 & 0.0 & 0.4 & 0.4 & 0.0 \\
\hline $3 / 10 / 2013$ & 1.62 & 0.05 & 0.01 & 0.00 & 0.00 & 0.00 & 0.01 & 0.03 & 0.00 & 0.00 & 0.1 & 0.0 & 0.0 & 0.3 & 0.1 & 0.0 \\
\hline $4 / 3 / 2013$ & 2.67 & 0.16 & 0.02 & 0.00 & 0.00 & 0.00 & 0.00 & 0.05 & 0.00 & 0.00 & 0.2 & 0.0 & 0.0 & 0.6 & 0.1 & 0.0 \\
\hline $5 / 9 / 2013$ & 2.63 & 0.61 & 0.21 & 0.12 & 0.38 & 0.17 & 0.01 & 0.63 & 0.31 & 0.01 & 1.3 & 0.7 & 0.2 & 0.8 & 0.3 & 0.0 \\
\hline $5 / 16 / 2013$ & 1.53 & 0.02 & 0.00 & 0.00 & 0.68 & 0.01 & 0.00 & 0.14 & 0.01 & 0.00 & 0.6 & 0.1 & 0.0 & 0.1 & 0.0 & 0.0 \\
\hline $5 / 21 / 2013$ & 2.03 & 0.43 & 0.13 & 0.00 & 0.14 & 0.00 & 0.07 & 0.17 & 0.05 & 0.00 & 0.7 & 0.4 & 0.2 & 0.2 & 0.1 & 0.0 \\
\hline 6/2/2013 & 0.99 & 0.00 & 0.00 & 0.00 & 0.00 & 0.00 & 0.00 & 0.00 & 0.00 & 0.00 & 0.0 & 0.0 & 0.0 & 0.0 & 0.0 & 0.0 \\
\hline $7 / 14 / 2013$ & 0.86 & 0.00 & 0.00 & 0.00 & 0.00 & 0.00 & 0.00 & 0.01 & 0.00 & 0.00 & 0.1 & 0.0 & 0.0 & 0.0 & 0.0 & 0.0 \\
\hline $9 / 28 / 2013$ & 1.36 & 0.00 & 0.00 & 0.00 & 0.01 & 0.00 & 0.00 & 0.03 & 0.00 & 0.00 & 0.0 & 0.0 & 0.0 & 0.0 & 0.0 & 0.0 \\
\hline $10 / 13 / 2013$ & - & $n / a$ & $n / a$ & $\mathrm{n} / \mathrm{a}$ & $n / a$ & $n / a$ & $n / a$ & $n / a$ & $n / a$ & $n / a$ & $n / a$ & $\mathrm{n} / \mathrm{a}$ & $n / a$ & $n / a$ & $n / a$ & $n / a$ \\
\hline $10 / 27 / 2013$ & - & $n / a$ & $n / a$ & $n / a$ & $n / a$ & n/a & n/a & $n / a$ & $\mathrm{n} / \mathrm{a}$ & $n / a$ & n/a & $n / a$ & $\mathrm{n} / \mathrm{a}$ & $n / a$ & $n / a$ & $n / a$ \\
\hline $10 / 31 / 2013$ & - & $n / a$ & $n / a$ & $n / a$ & $n / a$ & $n / a$ & $n / a$ & $n / a$ & $n / a$ & $n / a$ & $n / a$ & $n / a$ & $n / a$ & $n / a$ & $n / a$ & $\mathrm{n} / \mathrm{a}$ \\
\hline $11 / 22 / 2013$ & - & 0.00 & 0.00 & 0.00 & 0.00 & 0.00 & 0.00 & 0.00 & 0.00 & 0.00 & 0.0 & 0.0 & 0.0 & 0.0 & 0.0 & 0.0 \\
\hline $5 / 27 / 2014$ & 2.36 & 0.00 & 0.00 & 0.00 & 0.00 & 0.00 & 0.00 & 0.01 & 0.00 & 0.00 & 0.0 & 0.0 & 0.0 & 0.0 & 0.0 & 0.0 \\
\hline $5 / 28 / 2014$ & - & $n / a$ & n/a & $n / a$ & $n / a$ & n/a & $n / a$ & $n / a$ & $n / a$ & $n / a$ & n/a & n/a & $n / a$ & $n / a$ & $n / a$ & $n / a$ \\
\hline $6 / 10 / 2014$ & 1.70 & 0.01 & 0.00 & 0.00 & 0.06 & 0.00 & 0.00 & 0.04 & 0.00 & 0.00 & 0.1 & 0.0 & 0.0 & 0.0 & 0.0 & 0.0 \\
\hline 9/19/2014 & 1.88 & 0.00 & 0.00 & 0.00 & 0.00 & 0.00 & 0.00 & 0.01 & 0.00 & 0.00 & 0.0 & 0.0 & 0.0 & 0.0 & 0.0 & 0.0 \\
\hline $10 / 13 / 2014$ & 1.21 & 0.00 & 0.00 & 0.00 & 0.00 & 0.00 & 0.00 & 0.01 & 0.00 & 0.00 & 0.0 & 0.0 & 0.0 & 0.0 & 0.0 & 0.0 \\
\hline $\max =$ & 3.16 & 0.61 & 0.21 & 0.12 & 0.68 & 0.17 & 0.07 & 0.63 & 0.31 & 0.01 & 1.3 & 0.7 & 0.2 & 0.8 & 0.4 & 0.0 \\
\hline $\min =$ & 0.86 & 0.00 & 0.00 & 0.00 & 0.00 & 0.00 & 0.00 & 0.00 & 0.00 & 0.00 & 0.0 & 0.0 & 0.0 & 0.0 & 0.0 & 0.0 \\
\hline total $=$ & 24.00 & 1.43 & 0.43 & 0.13 & 1.28 & 0.19 & 0.08 & 1.18 & 0.39 & 0.01 & 3.2 & 1.4 & 0.4 & 2.5 & 1.0 & 0.1 \\
\hline mean $=$ & 1.85 & 0.10 & 0.03 & 0.01 & 0.09 & 0.01 & 0.01 & 0.08 & 0.03 & 0.00 & 0.2 & 0.1 & 0.0 & 0.2 & 0.1 & 0.0 \\
\hline median $=$ & 1.70 & 0.01 & 0.00 & 0.00 & 0.00 & 0.00 & 0.00 & 0.03 & 0.00 & 0.00 & 0.1 & 0.0 & 0.0 & 0.0 & 0.0 & 0.0 \\
\hline$s=$ & 0.70 & 0.19 & 0.06 & 0.03 & 0.20 & 0.05 & 0.02 & 0.17 & 0.08 & 0.00 & 0.4 & 0.2 & 0.1 & 0.2 & 0.1 & 0.0 \\
\hline$\% \mathrm{CV}=$ & 37.8 & 184.5 & 204.6 & 363.5 & 218.3 & 343.5 & 297.4 & 198.1 & 294.3 & 271.1 & 161.6 & 214.9 & 249.9 & 137.6 & 200.2 & 306.8 \\
\hline \multirow[t]{5}{*}{$\mathrm{n}=$} & 13 & & & & & & & & & & & & & & & \\
\hline & & \multicolumn{3}{|c|}{ Percent Reduction based on total } & & & & & & & & & & & & \\
\hline & & \multicolumn{3}{|c|}{ NO3-N (kg/ha) } & \multicolumn{3}{|c|}{ NH4-N (kg/ha) } & \multicolumn{3}{|c|}{ PO4-P (kg/ha) } & \multicolumn{3}{|c|}{$\mathrm{TN}$ (kg/ha) } & \multicolumn{3}{|c|}{$\mathrm{TP}(\mathrm{kg} / \mathrm{ha})$} \\
\hline & & in - out & out - ctrl & in - ctrl & in - out & out - ctrl & in - ctrl & in-out & out - ctrl & in - ctrl & in - out & out - ctrl & in - ctrl & in - out & out - ctrl & in - ctrl \\
\hline & & $70 \%$ & $71 \%$ & $91 \%$ & $85 \%$ & $55 \%$ & $93 \%$ & $67 \%$ & $96 \%$ & $99 \%$ & $58 \%$ & $69 \%$ & $87 \%$ & $62 \%$ & $94 \%$ & $98 \%$ \\
\hline
\end{tabular}

[a] " $\mathrm{n} / \mathrm{a}$ " indicates an error occurred in data collection and information was not included in analysis; "-." indicates no sample was collected for the event 